



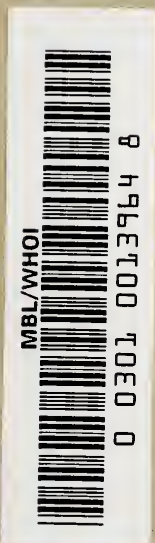




\section{-}

\section{-}

$-$

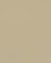


PHYCOLOGICAL MEMOIRS. 



\title{
PHYCOLOGICAL MEMOIRS
}

BEING

Researches made in the Botanical Department of the British Museum.

\author{
EDITED BY
}

GEORGE MURRAY, F.R.S.E., F.L.S.

WITH TWENTY LITHOGRAPHIC PLATES.

*

PARTS I., II., \& III.

*

DUlau AND CO., Soho Seuare, London.

I $892-5$. 


\section{$\Rightarrow 0 k$}

0279.

TO

WILLIAM CARRUTHERS ESQ., F.R.S., F.L.S., F.G.S.,

KEEPER OF THE DEPARTMENT OF BOTANY, BRITISH MUSEUM,

IN GRATITUDE AND FRIFNDSHIP.

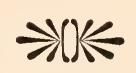




\section{PREFACE.}

IN every case but one I have verified every fact described in these Memoirs for the first time. The exception is Mr. Batters' Paper, which 1 did not presume to revise in this fashion, since his subject is one of which he knows much more than I do. I must cordially thank my fellow-workers for their kindness, consideration, and patience.

GEORGE MURRAY. 



\section{CONTENTS.}

\section{PART I. APRIL, I892.}

I.-On Splachnidiun rugosum Grev., the Type of a New Order OF Algæ. By Margaret O. Mitchell, former Bathurst Student, Newnham College, Cambridge, and Frances G. Whitting, former Student of Newnham College, Cambridge

II.-On a Fossil Alga belonging to the Genus CaUlerpa, from THE OOLITE. By The Editor. . . . . . . II

III.-On the Structure of Dictyosphenra Decne. By The Editor $\mathrm{I} 6$ IV.-On Malformations of AscophylLum and Desmarestia. By Ethel Surel Barton . . . . . . . . . 21

V.-On Conchocelis, a New Genus of Perforating Alge. By $E$. A. L. Batters, B.A., LL.B., F.L.S.

\section{PART II. MaY, I893.}

VI.-Notes on the Morphology of the FucACEA:- . . . 29 Coccophora LANGSDorfil Grev. By A. Lorrain Smith . . 30 Selrococcus axllLaris Grev. By A. Lorrain Smith . . 32 XiPHOPHORA BILLARDIERII MONT. By E. S. Barton . . 35 Notheia anomala Bail. and Harv. By M. O. Mitchell . $3^{6}$ SARCOPHYCUS POTATORUM KÜtZ. By F. G. Whiting . . 38

ViI.-On Chlorocystis sarcophyct, a New Endophytic Alga. By F. G. Whitting . . . . . . . . . $4 \mathrm{I}$

VIII.-ON HALICYSTIS AND VALONIA. By The Editor . . . . 47

IX.-On the Structure of Hydroclathrus Bory. By M. O. Mitchell 53

X.-On the Cryptostomata of Adenocystis, Alaria and SacCORHIZA. By The Editor . . . . . . . 59

Xi.-A Comparison of the Marine Floras of the Warm Atlantic, Indian Ocean, and the Cape of Good Hope. By The Editor 65 


\section{PART III. APRIL, I895.}

XII.-A New Part of PAchytheca. By The Editor. . . . $7 \mathrm{I}$ XiII.-Calcareous Pebbles formed by Alge. By The Editor. With List of Diatoms. By E. Grove . • . . . 74 XIV.-Notes on the Sori of Macrocystis and Postelsia. By $A$. $L$. Smith and F. G. Whitting . . . . . . . 83 XV.-A Comparison of the Arctic and Antarctic Marine Floras. By The Editor and E. S. Barton . . . . . . 87 


\section{ON SPLACHNIDIUM RUGOSUM, GREV., THE TYPE OF A NEW ORDER OF ALGAE.}

HISTORICAL. - The earliest record of the subject of this research is the description by Linnæus * of Ulva rugosa, a plant collected at the Cape of Good Hope by Koenig. His description was based on two specimens preserved in his herbarium, one of them of mature stature, the other considerably younger. Dawson Turnert describes and figures it under the name of Fucus rugosus, and his illustration was drawn from the mature specimen in the Linnean herbarium, of which it is a good representation. He mentions that this plant had been collected in New Holland by Robert Brown, who obtained it also at the Cape of Good Hope, as found on consulting his herbarium in the British Museum. The next noteworthy record is that by Suhr + , who, describing a specimen collected by Drege, assigned it a place in the genus Dumontia, to which the dried specimens have a certain outward resemblance. Greville§ next founded the genus Splachnidium for its reception, and it remains still the only representative of this generic type. In the meantime the plant had been collected by Lesson \| in New Zealand, and a short description and figures are given by Kützing in Tabula Phycologica.T Harvey gives details of its distribution, and describes it in his Genera of South African Plants (p. 394), and in the Flora of New Zealand (vol. ii., part ii., p. 215), and figures it on plate XIv. of his Phycologia Australica. Lastly, we must note a paper by Mr. R. MI.

\footnotetext{
* Mantissa, p. 31 I, and Syst. Nat. Ed. Genel. II., p. 139 I.

† Fuci, vol. iii., p. 118 , tab. 185 .

$\ddagger$ Beiträge zur Algenkunde in Flora, I840, p. 275.

$\S$ Synopsis, p. xxxvi.

\|V Voyage d'Astrolabe. Sert. Astrolab., p. I 40.

भा Vol. x., p. 4 .
} 
Laing,* in which the author gives a brief note of his observations on Splachnidium rugosum.

Specimens collected by Harvey at the Cape and Australia have been re-examined by us, as also those collected by Dr. Lyall in New Zealand, and quoted by Harvey. In addition to these, we have examined specimens from Seal Island, 'Challenger Expedition ;' from the Cape, collected by Mr. Boodle; excellent spirit specimens from the same region by Mr. Scott Elliott; and from New Zealand by Dr. Berggren, all of them in the British Museum.

The Plant of Splachnidium rugosum consists of from five to six branches or fronds, which spring from a small conical disc, the base of which rests on the substratum to which the plant is attached. Each branch has a well-marked main axis of cylindrical form, which gives off at irregular intervals smaller branches, similar in form and structure. The surface of the thallus is marked with numerous pits containing hairs in their young state, and, at a later stage, reproductive organs.

The Minute Structure of the Thallus.-Transverse sections of a branch taken at any point between the apex and the base, but exclusive of the pits just mentioned, show on the whole a uniform structure. The external wall consists of rows of closely placed cells, on the inner side of which lie strands of hyphal filaments surrounding a mass of mucilaginous substance, which entirely fills the central part of the branch (plate II., fig. I). Five layers of cells may be distinguished, the outer layers being clearly defined from those that lie more internally by the shape of their cells. For the sake of clearness in description, we will venture to call the two outer layers epidermal, and the inner ones cortical layers. The cells of the epidermal layers are small and approximately cubical in shape. They are filled with a dense granular olive-brown protoplasm; on staining with carmine or picric aniline blue, a nucleus is apparent. The cells of the cortical layers, when first formed, are polygonal; at a later stage they become ovate by unequal growth. The cell contents are olive-green when young, changing to brown when maturity is reached.

The strands of filaments lie, some immediately below and in contact with the innermost cortical layer, while the remainder, becoming more and more separated from one another, lie in the periphery of the mucilage with which the central part of the branch is filled; they run in all directions, but take, on the whole, a longitudinal course from base to apex. Each strand consists of one large central filament, surrounded by a varying number of small ones. The former are made up of elongated thin-walled

* Observations on the Fucoidea of Banks's Peninsula (Trans. and Proceedings of the New Zealand Institute, vol. xviii., 1885). 
cells, which branch and anastomose irregularly (plate 1., fig. 2, $a, b, c$ ). In the young state there is active cell-division (plate II., fig. 3 ), and, as each mature cell is greatly elongated, the granular protoplasm which at first fills the whole cell becomes somewhat attenuated, and in some cases, though this appearance is, perhaps, owing to the method of preservation, ruptures altogether, so that a mass of protoplasm remains at each end of the cell overlying the septum, and gradually tapering towards the centre of the cell. The small filaments are produced from the large ones by lateral branching; the individual cells are very long, and the cell-cavity is small (plate I., fig. $3, a, b, c, d$ ).

The disc from which the branches spring is like the rest of the thallus in colour, brown or olive-green, and it has no special organs of attachment. A section taken in any direction through the lower part, i.e., the region below the origin of the branches, shows a mass of closely woven unbranched septate filaments (plate II., fig. 6), with thick walls and a small amount of cell-contents. These are woven together so that interhyphal spaces are absent ; where they approach the surface, their arrangement is looser and their apices project freely; these latter contain a dense granular protoplasm. As in the Laminariacee and Fucacee, the plant is covered with a mucilaginous substance. In Splachnidium rugosum this is very abundant, and not only covers the outside of the thallus, but is largely developed within, and fills the branches. On staining some of the filaments with hæmatoxylin, the stain is taken up by an otherwise invisible sub. stance, which surrounds them, forming a thick coating on the outside of the wall. The same appearance shows itself on staining a piece of the thallus.

INCREASE IN LENGTH AND APICAL CELL.-The chief increase in growth of the plant takes place as the result of the activity of a zone of meristematic tissue which surrounds the actual apical cell, and thus a contrast is offered to the mode of growth which obtains in the Fucacee. The apical cell (plate II., fig. 4), in Splachnidium rugosum differs entirely in appearance from the surrounding meristem; it has a pear-shaped body bounded by a thick transparent mucilaginous wall, and a filiform basal process stretches towards the interior of the thallus. This cell and the very active surrounding meristem are sunk in a slight depression; the two outer layers of the meristem by radial division form the epidermal cells, which continue to divide radially until the part of the thallus in which they lie has reached maturity. Some of the inner cells of the meristematic zone form the adult cortical layers; these are at first polygonal in shape, and when once formed do not again divide, each increases in size and becomes oval; by subsequent separation of these cells the cortex keeps pace with the 
growing epidermal layers. The cells of the meristematic zone lying internally and immediately round the apical cell, divide tangentially and give rise to large filaments; the young cells undergo division and grow in length, they branch and anastomose repeatedly, so that below the apex there comes to be a filamentous network of cells filled with a dense olive green prctoplasm (plate II., figs. 3 and 4); at this stage young lateral filaments are as yet unformed.

The young cells of the outer epidermal layer, with the exception of those lying directly round the apical cell, give rise to hairs. Each hair is produced as a small protuberance which increases in length, and is finally cut off by a wall ; cell divisions follow till a short filament is produced. The cells of an adult hair are slightly elongated, sometimes the upper members of a filament are spherical or bulge unilaterally, so that the whole hair takes on a moniliform appearance, and the protoplasm which has shrunk away from the wall lies in the centre as an irregular mass (plate II., fig. 4). All the hairs bend towards the apical cell, and it is to be noted that in those which are destined to become moniliform the bulging appears first on the side away from the apex. These hairs are referred to by Mr. Laing as being possible antheridia.*

The apical cell persists throughout the life of the plant, and not only does it appear at the apex of the main branch, but cells of the same kind are found at other points where growth is taking place, e.g., in the young conceptacles and at the point of formation of lateral branches. It seems as if its appearance were the herald of every local development.

When a new branch is about to be produced, one of the young epidermal cells not far from the apex, and still in the region covered by the apical hairs, develops a markedly mucilaginous wall, and takes on the cliaracters of an apical cell. The cells in its immediate neighbourhood divide in the same way as they do at the primary apex, and cause the thallus to grow out at this point (plate II., fig. 2); the filaments which were originally below the thallus branch repeatedly and form a mass of tissue, while the meistem round the apical cell produces new filaments in the same way as that already described. As the branch increases in size, the basal filaments collect into strands which run at first radially, and then longitudinally, below the cells of the newly formed cortex, and the new branch shows precisely the same structure as the main axis. The apical hairs remain, and are carried upwards by the growing branch.

The Development of the Conceptacles.-The first indication of the formation of a conceptacle is seen in the alteration of one of the young epidermal cells lying not far from the apical cell. By change in shape and 
character of its wall this becomes an exact copy of the apical cell. The basal process grows between the cells of the thallus towards the centre of the branch; at its extremity it is club-shaped, and in some cases is united to one of the cells of the large filaments, which forms a small outgrowth at the point of contact (plate III., fig. I). It appears to us that this junction may form a point of contrast with the vegetative apical cell described above, and we may perhaps note a further although slight distinction in some indication of casting of the external layers of the mucilaginous wall in the latter case (plate II., fig. 4), which we have never certainly observed in the conceptacles. This peculiarly modified cell of the conceptacle is homologous with the initial cell of Prof. Bower,* but it undergoes no division and no further development. The epidermal cells lying round it undergo division, and the neighbouring cortical cells increase in size. These causes combine to place the initial cell in a depression (plate II., fig. 7). Hairs arise from the youngest epidermal cells, while others, which were formed earlier, surround the mouth. At this stage, therefore, a young conceptacle is a cylindrical depression in the thallus, with older hairs lining the mouth, while young hairs are being produced round its sides, and the upper part of the initial cell has come to stand out prominently from its base. There is thus a marked contrast with the sexual conceptacle of Fucus serratus. In Splachnidium rugosum the hairs arise while the formation of the conceptacle is in progress, and older hairs line the ostiole, which is never closed, while in Fucus serratus a young conceptacle with a very small ostiole is formed before the appearance of any hairs. In this plant also the initial cell shrivels and finally almost disappears before the production of any hairs; in Splachnidium nugosum the initial cell remains a most prominent object in the conceptacle till it has reached maturity.

By repeated radial division of the lining cells the conceptacle gradually enlarges, and the base comes to be of greater circumference than the mouth; the form of the conceptacle is, however, never flask-shaped, with a small ostiole, as in many Fucacee. The hairs which are developed from the lining cells are long, septate, and unbranched, and they increase in length by successive divisions at the base. At this stage the conceptacles present the appearance of the Fasergriibchen of many Fucacea, the tufts of hair extending a long distance beyond the ostioles (plate III., fig. 3). Later reproductive organs are produced among the hairs in the form of long clubshaped sacs filled with numerous spores (plate III., figs. 4 and 5). We shall speak of these organs as sporangia. The number of sporangia in a single conceptacle increases with its age, and in a mature conceptacle the hairs

\footnotetext{
* Formation of the Conceptacies in the Fuarca. Q.J.M.S. ISSI.
} 
are chiefly confined to the region surrounding the ostiole, only a few remaining between the sporangia. Conceptacles which may be said to have passed their maturity contain sporangia which have lost their contents, only the clear hyaline walls remaining (plate III., fig. 5). The sporangia are ruptured irregularly at the apex, and strongly resemble those of the Laminariacee (cp. plate III., fig. 6, e, and fig. 8). They are persistent, and in this offer a contrast to the empty oogonia of the Fucacee, which disappear after a short time.

Structure and Development of the Sporangium. - A sporangium arises as a papillose protuberance of one of the lining cells of the conceptacle. This elongates and enlarges into a club-shaped body, having its base sunk between the adjacent cells of the wall of the conceptacle, and it becomes completely filled with a dark-coloured protoplasm. When the sporangium has attained its full size, the protoplasm becomes differentiated into spores, the differentiation proceeding simultaneously throughout the whole sporangium. The spores do not entirely fill the cavity of the mature sporangium, the wall of which gives the cellulose reaction when treated with iodine and sulphuric acid.

It should be noted that there is no division of the original papillose protuberance into two cells, forming stalk-cell and sporangium respectively. In all Fucacee, on the other hand, the oogonium is supported by a pedicel cell, which is cut off from the protuberance in the very beginning; only in Pelvetia, so far as is known, is this cell somewhat obscure, owing to the fact that it does not elongate to form a stalk as in other cases.

The sporangium is unilocular. Treatment with eau de javelle dissolves the undifferentiated protoplasm or the spores within, but leaves no trace of an intrasporangial network. Reinke* has shown that similar treatment of the multilocular sporangia of some other Algæ brings out a well-defined intrasporangial network. That there is no inner membrane enclosing the spores may also be demonstrated by the action of eau de javelle.

The spores when liberated by pressure from a sporangium of average size are found to number from 500 to 600 ; they measure approximately $\frac{1}{200} \mathrm{~mm}$. in diameter. It may be noted that this is also the average diameter both of an antherozoid of Fucus serratust and of a zoospore of the Laminariacea. It is calculated that the volume of an oosphere of Fucus serratus is $20,000-30,000$ times as great as that of an antherozoid of the same plant. These figures therefore express the ratio between the volumes of the oosphere of Fucus serratus and of the spore of Splachinidium rugosum.

* Reinke, Atlas deutscher Meeresalgen, p. 49, tab. 32, fig. I I.

+ J. Thuret, Etudes Phycologiques. 
The reproductive organs here described are the only ones which have been found in Splachnidium rugosum; and there are before us three possible interpretations of these organs:-

I. That they may be oogonia containing a very large number of small oospheres.

2. That they may be large antheridia.

3. That they may be sporangia like those of the Laminariacee containing zoospores.

We will proceed to a consideration of each of those possibilities. In connexion with the first we must note that Mr. R. M. Laing, in the paper cited above, refers to these organs in the following words:- 'The conceptacle is surmounted by a ring of hairs, and in its interior contains a number of unbranched hairs. The oogonia are obscurely pedicelled and developed in the cells lining the wall of the cavity. Each oogonium gives rise to a large number of oospheres, thus differing from all the other Fucacee that have hitherto been described. Each oosphere is very small compared with the oospheres of any of the other Fucacee.' A rough figure (op. cit., plate X., fig. 7) accompanies this note, and it is apparent that the author has anticipated the view that these bodies are oogonia with numerous minute oospheres. Harvey* also regarded them as oogonia. Mr. Laing, believing these bodies to be oogonia, and failing to find antheridia developed as in typical Fucacee, suggests, as has been already said, that the antheridia are to be found in the peculiarly shaped hairs which cover the apex of each branch; that these are merely hairs has been already shown.

That the sporangia of Splachnidium rugosum, however, are not oogonia homologous with those of the Fucacece appears obvious from the following facts :-

I. The enormous number of the spores (500-600), as compared with the largest number of oospheres in an oogonium of the Fucacece, i.e., eight.

2. The small size of the spores, the bulk of an oosphere of the Fucacee being 20,000-30,000 times as great. Though deprecating size as an important characteristic, surely there is here a sufficiently wide margin to entitle us to base an argument upon it.

3. The absence of a pedicel cell.

4. The absence of an inner membrane within the wall of the sporangium.

Secondly, that they are not antheridia homologous with those of the Fucacee appears plain from the following facts :- 
I. The enormous number of the spores (500-600) compared with the largest number of antherozoids contained in the antheridia of the Fucacce, i.e., 64 .

2. The large size of the sporangium compared with that of an antheridium.

3. The production of sporangia directly from the cells lining the conceptacle, whereas antheridia are always borne on hairs within the conceptacle.

In the face of these facts, it is impossible to regard the sporangia of Splachnidium rugosum as homologous with either the oogonia or the antheridia of the Fucacea. We are, therefore, led to the third possible interpretation, i.e., that they are sporangia, containing zoospores homologous with those of the Laminariacee. It is in those very points in which the sporangia of Splachnidium differ so remarkably from the oogonia or the antheridia of the Fucacea that we note their striking similarity to the sporangia of the Laminariacee. The size of the sporangium, its unilocular nature, its single wall, the number of the spores, the size of the spores, and the persistence of the empty spore cases, all point definitely to the conclusion that these sporangia are homologous with those of the Laminariacee. A comparison of fig. 6 with fig. 8 (plate III.) will show the general resemblance more clearly than it can be expressed in words. Whether the spores produced in these sporangia germinate directly or conjugate first, or, in the latter case, whether they show any sexual differentiation, are questions which can only be settled by the examination of fresh material and the cultivation of the spores.

While, then, the characteristics of Splachnidium nugosum are such that it can be placed in no existing natural order of the Phaeophycea, its nearest allies appear to be the Fucacea on the one hand and the Laminariacee on the other. In its vegetative structure, i.e., in the nature of its thallus and in the existence of conceptacles, Splachnidium bears a resemblance to the Fucacee; it differs from them, however, in its mode of growth, the former increasing by means of an apical meristem, while the growth of the latter is due to divisions of an apical cell. In the presence of an apical meristem Splachnidium approaches the Laminariacea, but at the same time there is no plant in this order which has a cell corresponding to the remarkable cell found at the apex of the main axis and lateral branches of Splachnidium. In its reproduction it is allied to the Laminariacee, and the production of sporangia within conceptacles might seem to point to a narrower limitation of the fertile sorus of plants of this order, recalling the difference between perithecium and apothecium in the fungi. 


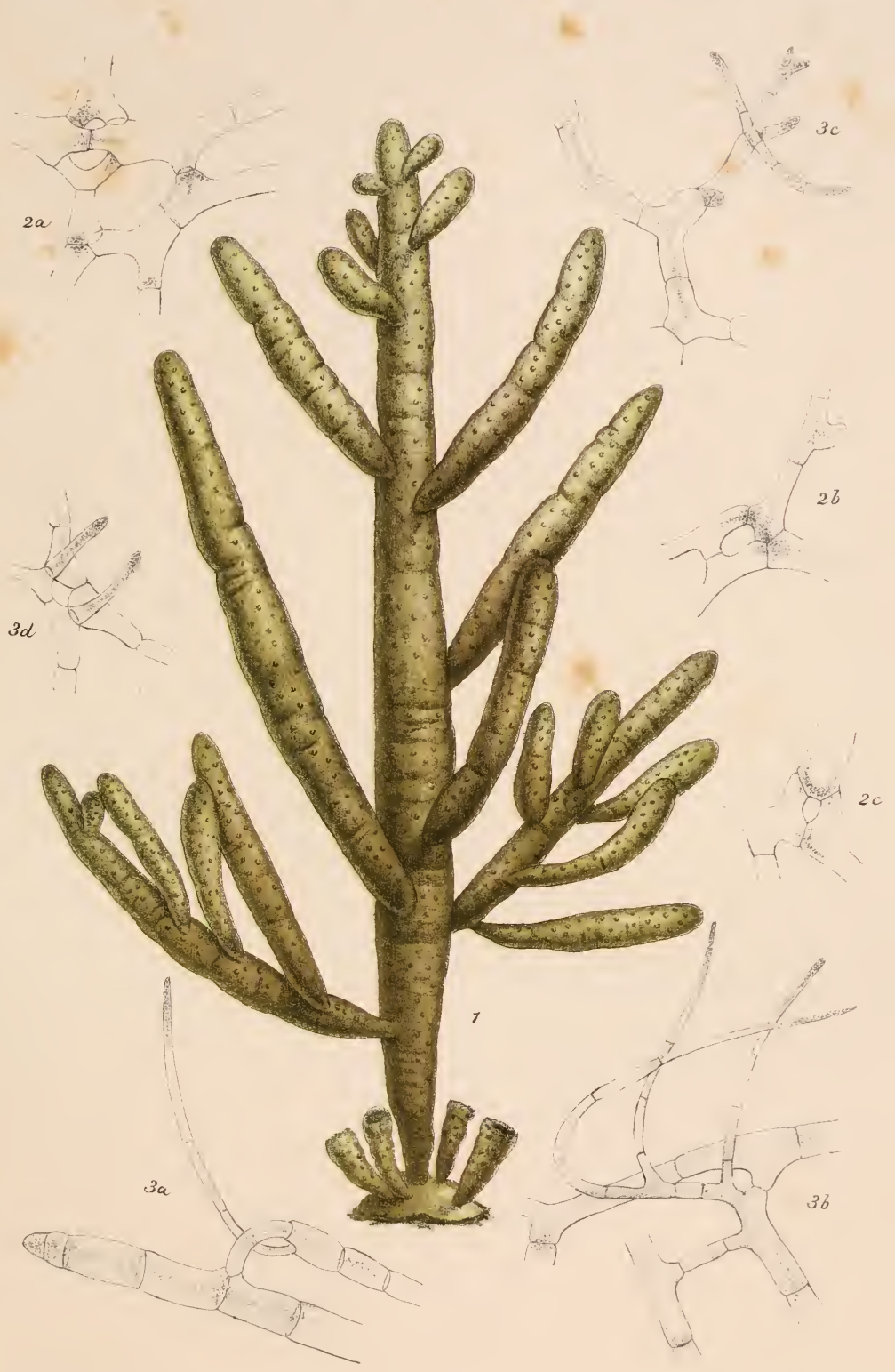




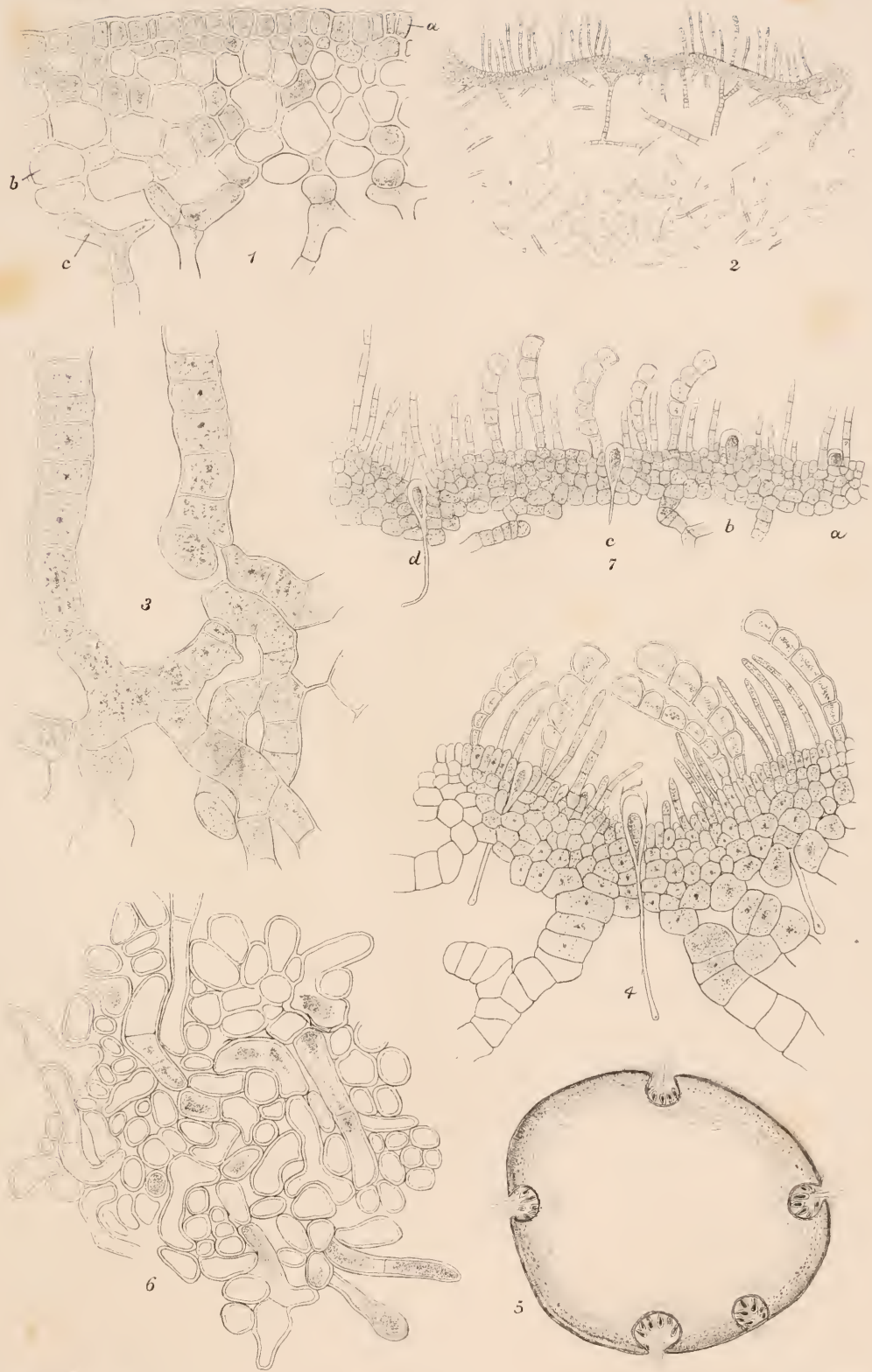

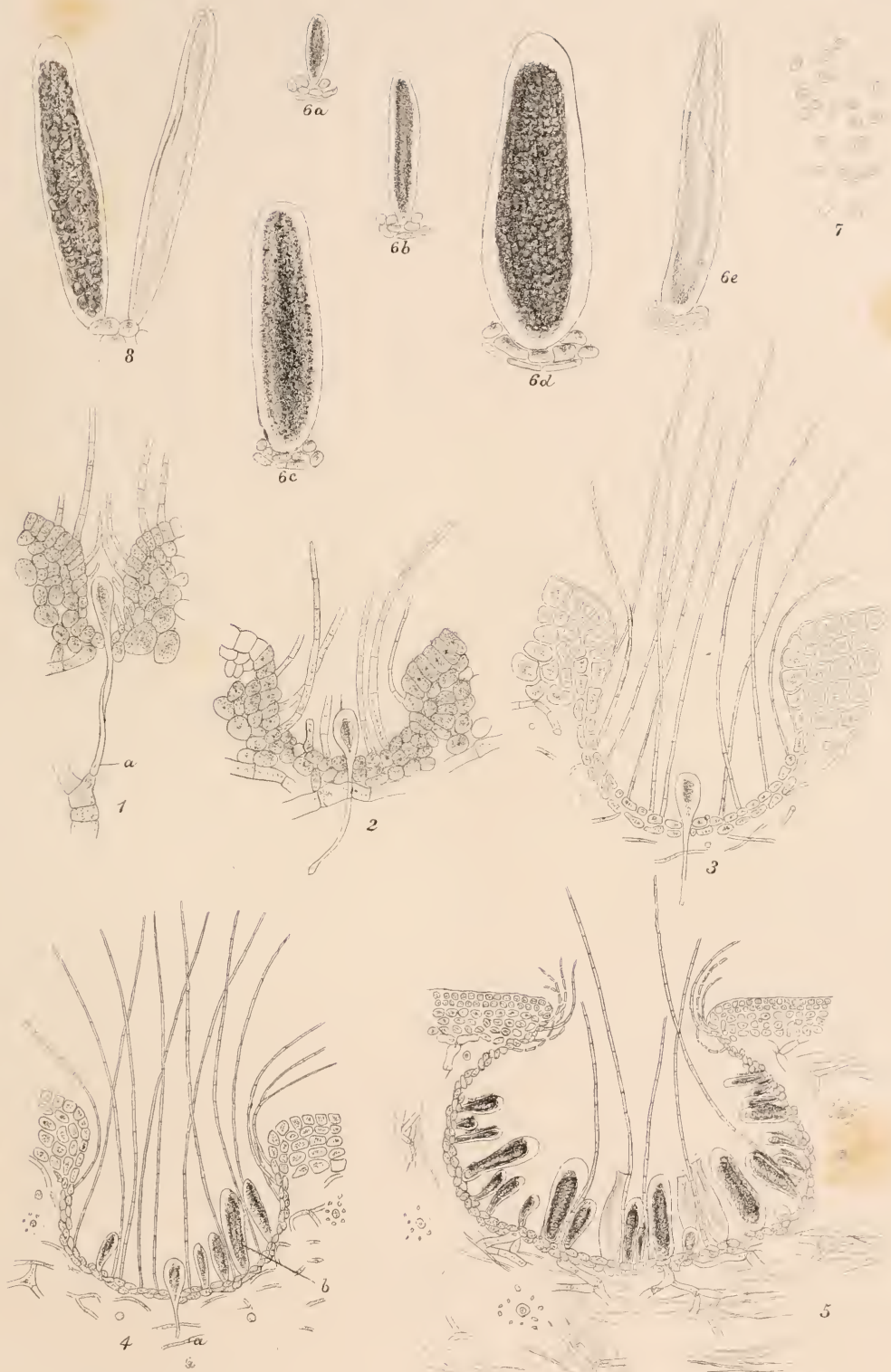

$\therefore 3$ का

Berjeau \& Highiey hth 


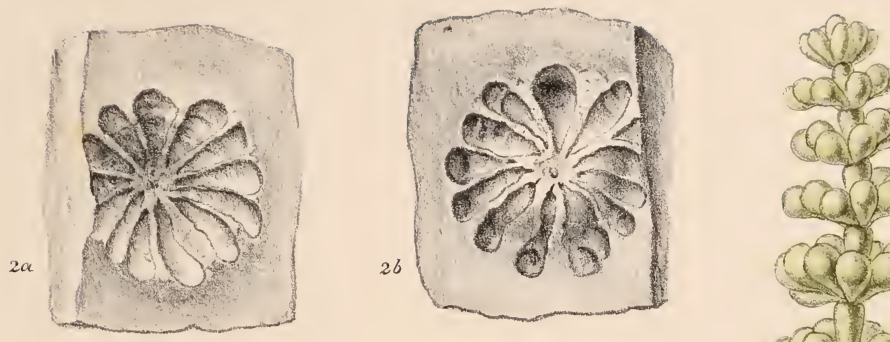
(1) 120 (c) $(15)$ (3) $\left(\mathrm{x}^{2}+2\right)$ t (f) $(1)$ (1) (1) $(1, y)$
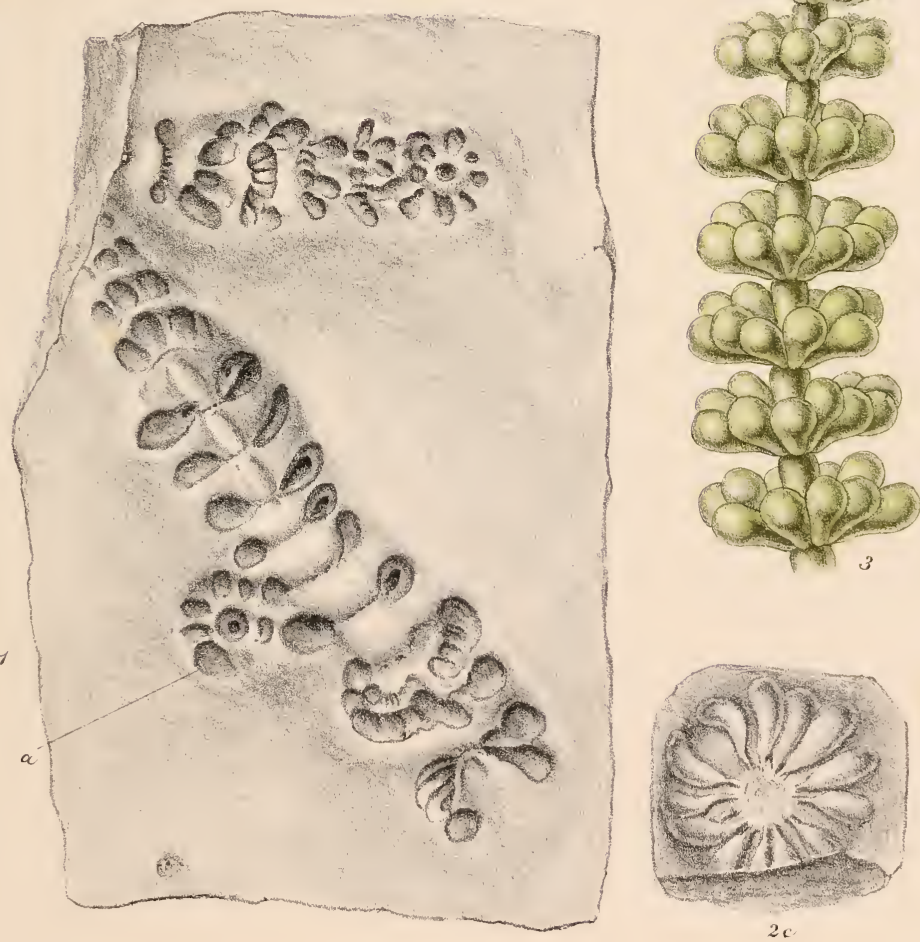

The sum of the characters of Splachnidium so expressly excludes it from any existing natural order that there is no other course open to us than to establish one for its reception under the name of Splachnidiacea, the main character of which shall be, reproduction by spores contained in sporangia which are borne within conceptacles. It is possible that further investigation of those genera of the Fucacee, about which little is at present known, may lead to the discovery that such are really allied to Splachnidium, and to their inclusion in the order. We may define this order as follows, the subsidiary characters being necessarily provisional: - Splachnidiacea. - Algæ olivaceæ, per fulcrum discoideum e fibris radicalibus coalescentibus formatum, substrato affixæ, frondibus ramosis, externe e cellulis parenchymatibus interne e filis inter stratum mucosum currentibus compositis. Sporæ in sporangiis clavatis inclusæ inter paranemata simplicia articulata in scaphidiis infra superficiem excavatis, per totam frondem dispersis, collectæ.

Finally we wish to record our thanks to Mr. George Murray for pointing out this research to us, and for his help and criticism during the progress of our work.

\author{
MARGARET O. Mitchell \\ (Former Bathurst Student, Nezonham College, Cambridge). \\ Frances G. WhitTing \\ (Former Student of Newonham College, Cambridge).
}

\title{
EXPLANATION OF PLATES.
}

\section{Plate I.}

Fig. I. Mature plant of Splachnidium rugosum. Natural size.

Fig. 2. a. b. c. Mode of junction of some of the large filaments ( $\times 235$ ).

Fig. 3. $a . b . c . d$. Large filaments not far from the apex, giving rise to small lateral branches $(\times 235)$.

\section{Plate II.}

Fig. I. Transverse section of Thallus $(\times 235) \cdot a$. Epidermal layers. $b$. Cortical layers. c. Filament.

Fig. 2. Section of developing branch with its apical cell $(\times 55)$.

Fig. 3. Young filaments from near the apex $(\times 235)$.

Fig. 4. Section through the apex showing the apical cell with its basal process and mucilaginous layers being shed externally, the apical hairs and the large filaments in process of formation $(\times 235)$. 
Fig. 5. Section across a branch showing the relative arrangement of tissues in the thallus and position of conceptacles.

Fig. 6. Section of part of the disc showing interwoven filaments with free apices $(\times 235)$.

Fig. 7. Four stages in the development of a conceptacle $(\times 235)$. $a$. The youngest stage hardly to be distinguished from an epidermal cell. b.c.d. Older stages $(\times 235)$.

\section{Plate III.}

Fig. 1. Older conceptacles with young hairs in process of formation. a. Point of contact of basal process with a large filament $(\times 235)$.

Figs. 2 and 3. Further stages of Fig. I $(\times 235)$.

Fig. 4. Conceptacle with developing sporangia. $a$. Initial cell. $b$. Young sporangium.

Fig. 5. Mature conceptacle.

Fig. 6. a.b.c.d. Successive stages in the development of a sporangium ( $\times 235)$. e. Empty sporangium ( $\times 235)$.

Fig. 7. Spores $(\times 440)$.

Fig. 8. Sporangia of Sacchoriza bulbosa, after Thuret. Recherches sur les Zoospores des Algues. Ann. Sci. Nat., sér. 3, tom. xiv., plate xxx., fig. 6 ( $\times 330)$. 


\section{ON A FOSSIL ALGA BELONGING TO THE GENUS CAULERPA FROM THE OOLITE.}

ANY trustworthy evidence of the occurrence of Algæ as fossil remains is welcome, for the two reasons that the undoubted records of the preservation of such organisms are scanty, and that every one placed beyond doubt enables us the better to deal with numerous cases hitherto uncertain, and to judge of their claims to recognition. A large number of supposed Algæ have been described by Brongniart and other older writers under the names of Chondrites, Confervites, Caulerpites, etc., and the validity of their position has been disputed, as I believe, with success by botanists, who have pointed out that such markings as are represented by these names may well be the result of trails of animals and other casual impressions, or the remains of other organisms, both plants and animals. Of the rights of this discussion, which has been carried on mainly by Nathorst* and Saporta, $\uparrow I$ have no claim to judge other than that given by a working knowledge of the forms of living Algæ, but a recent examination of fossil forms in the Geological Department of the British Museum has inclined me to the point of view of Nathorst and those who with him reject the validity of numerous recorded fossil Algæ. No more eloquent testimony could be sought against the views of Saporta than the plates of his own memoir just cited. It is scarcely conceivable that a scientific inquirer should not only accept such forms as many of those figured by Saporta, but even use them in answer to a challenge.

* Mémoire sur quelques traces d'animaux sans vertèbres, etc., et de leur portée palaontologique, Kongl. Svensk. Vetenskaps-Akad. Handl., Bd. 18, No. 7, 1881, contains bibliography ; Nouvelles observations sur des traces animaux; Ibid, Bd. 21, No. 14, I886.

+ A Propos des Algues fossiles par le Marquis de Saporta. Paris, G. Masson, I882. 
If we take as trustworthy only such cases as exhibit microscopic evidence of minute structure, we have before us a scanty record of forms. The earliest of all is the Nematophycus of Carruthers* from the Devonian, which exhibits its structure so plainly that there need be no hesitation in accepting the position assigned it by its author in the Udotea, a sub-order of Siphonea. In the same beds there is found another organism, Pachytheca, described by Sir Joseph Hooker, $\dagger$ and others; but its claims to rank with the Algæ need a more cautious examination. Mr. Barber + has recently described it in two papers. In the former he obviously and confessedly mistook the microscopic evidence, and in the second giving a detailed and accurate description of its structure, while avoiding 'theoretical considerations concerning the systematic relations of the plant,' he assigns it a place near Cladophora. I have recently examined the beautiful slides of Pachytheca prepared by Mr. John Storrie, who most kindly placed them at my service, with some hope that it might prove to be an encrusting algal growth surrounding some spherical Alga, such as a Valonia, and pushing its rhizoids within the sphere; but this view, which at one time appeared to me a highly probable explanation, was abandoned after repeated examinations and comparisons with living forms. I confess to feeling as little attached to this view as to Mr. Barber's determination of it (near Cladophora), which it would be hard to get a phycologist to accept.

Its claims even to be reckoned an Alga may be regarded as still doubtful. There is then a long break until we come to the Tertiary rocks, in which besides the fossil Diatomacee we have a series of Algæ belonging to the Dasycladece and other Siphonee described by Munier Chalmas, $\S$ and forms of Lithothamnion (Floridee), and several Characee. These are those which rest on the solid ground of structure, and the record is bare enough.

It would be going too far, however, to restrict our view absolutely to fossil Algæ exhibiting such structure, or even to those possessing a rind of coal, which Nathorst considers indispensable evidence. With regard to the latter view it has been pointed out that coal 'may entirely disappear in the course of time from remains that are undoubtedly organic, if they are deposited in a porous rock.' $\|$ There are many fossil plants the determination of which is unquestionably correct, affording no other characters than those given by impressions of outward form, and I may cite as a

* Monthly Micr. Journ., I872, vol. viii., p. I60; and 1873, vol. x., p. 208.

+ Journ. Geol. Soc., 1853, p. I2 ; and Annals of Botany, vol. iii., No. x., 1889.

$\ddagger$ Annals of Botany, vol. iii., No. x.; also ibid., vol. v., No. xviii.

$\S$ Comptes Rendus de lAcad. des Sc, vol. lxxxv. (1877), pp. 814-817. See also Bull. Soc. Geol. de France, 3 sér., vol. vii., p. $66 \mathrm{I}$.

I| Graf zu Solms-Laubach. Fossil Botany, p. 47. 
familiar example the case of many ferns in which, owing to the characteristic outward forms on the one hand, and the excellence of the impressions on the other, safe determinations of genera have been made. An objection to the application of this method to the Algæ might be made at the outset, that it would only lead us back again along the old path encumbered with the débris of Chondrites and the like. I venture to think, however, while agreeing with Nathorst in the main, that he goes too far in denying that this method may be employed with proper safeguards, such as a consideration of the nature of the bed as obtained from other remains, the perfection of the remains themselves, and the degree of their correspondence with the bodies of living Algæ, especially if the group in question be one of steadfast outward form. This latter character is one unfortunately rarely to be met with among Algæ. Their extremely plastic bodies are readily moulded by their immediate environment, and systematic literature is loaded with records of growth-forms erroneously described as independent species.

Of all genera of Algæ, one might almost say of plants, there is none which varies through a wider range of outward forms than Caulerpa; but the species themselves are, on the other hand, remarkably constant in their characters. It is only here and there that we find one species run into another, as the saying is. The variation is of a noteworthy character, since the outward forms are astonishingly like those of the higher plants, as their names cactoides, taxifolia, Abies marina, ericifolia, cupressoides, thujoides, juniperoides, fontinaloides, Selago, Lycopodium, hypnoides frequently show, while their internal structure is one characteristic of the genus in a remarkable degree. The whole body of the plant consists of a single multinucleate cell, and the walls are sustained by an interwoven system of trabeculæ or cross beams and struts traversing the interior in all directions, forming a great plexus, but at no point interrupting the continuity of the cell. The Caulerpe form a group of Siphonece, the same order to which belong those other Algæ alluded to above, described by Munier Chalmas, and Nematophycus as well. Nature seems to have shown in this genus the utmost possibilities of the siphoneous thallus in an exhibition of the outward forms of the higher plants-a prophecy, as it were, of what was otherwise accomplished by the building up of cellular and vascular tissues. Small wonder, then, if Caulerpa has been chosen by palæontologists as a convenient limbo for placing all imperfect sorts and conditions of so-called fossil Algæ. I have examined nearly every species known to science of those at present existing, and have seen a considerable number of them alive in West Indian waters, and with this aid to judgment I may say that of all the described fossil Caulerpe and 
Caulerpites of which I have seen specimens and figures, there is not one which might not with equal propriety be assigned a place elsewhere within or without the vegetable kingdom.

With due consideration of all these facts, I yet propose to submit reasons for believing that we have a veritable fossil Caulerpa represented by specimens from the Kimmeridge clay. This fossil was discovered by Mr. Damon, of Weymouth, and described * by him as an Equisetaceous plant. He sent specimens to Mr. Carruthers, who very kindly placed them in my hands for description, with the remark that they might prove to be a true Caulerpa. I have examined other specimens of this fossil in the Geological Department of the British Museum, and am much indebted to the Director-General of the Geological Survey for the permission to use and figure here (plate V., fig. I) an excellent specimen in the Museum of Practical Geology, first pointed out to me by Mr. E. T. Newton. These specimens represent a cast in the round (not a flattened impression) of a verticillate organism. We are, therefore, on much safer ground in describing it than we should be in dealing with a mere impression. In some specimens the hollow interior of the axis is now filled in places with a solid substance crystallised from the minerals dissolved in the water. The specimens come from a bed of marine origin, and we may assume, without absolutely excluding other possibilities, that the remains represent a sea-weed, if a plant at all. No zoologist has been forthcoming who will claim it as an animal, and on the other hand there are strong positive reasons for believing it to be an Alga. In the first place, the stature, habit, and mode of branching favour this view, and the correspondence with existing species of Caulerpa is so close, that, were such a specimen clothed with cellulose walls and endued with living contents to be placed before a phycologist, he would have little hesitation in assigning it a place near Caulerpa cactoides, Ag. From this species, in point of fact, the specimens in question differ in one single respect of outward structure, viz., in the fossil we have verticillate ramenta in place of the opposite pairs-or, as it may be said, whorls reduced to two members-of the living species. In the lower whorls of the fossil (plate IV., fig. 2) there are thirteen ramenta in each whorl, and the number diminishes towards the apex. In plate IV., fig. $1 a$, there is a whorl which must be near the apex of a specimen exhibiting only six. The ramenta are constricted at their insertion, and are club-shaped in form, as in C.cactoides. Unfortunately we do not have the creeping surculus. The following may be taken as a description of the species, with which I have much pleasure

* Supplement to the Geology of Weymouth, Portland, and Coast of Dorset, 1888. Plate XIx., figs. 12, 12a. 
in associating Mr. Carruthers' name:-Caulerpa Carruthersii, n. sp.: frondibus erectis, annulato-constrictis, simplicibus, ramentaceis, ramentis verticillatis, clavato-obovatis, strictura conspicua a rachide sejunctis, quasi articulatis; surculus nondum inventus.

The species of Caulerpa at present existing are mostly tropical, a few of them reaching as far north as the Mediterranean and as far south as the Cape of Good Hope. We may say approximately that they are confined within the fortieth* parallels of north and south latitude, but occur more plentifully as we reach the equator from either hand. If we may judge by the marine fauna of the Kimmeridge clay, it is such as would favour the view of the climate being suitable to the occurrence of Caulerpa.

Though I do not venture to claim for this determination the certainty which would be yielded by tissues preserved in a state fit for microscopic examination, yet I would point out that we are dealing here with no mere flattened impression, but with a cast exhibiting in the round all the details of external conformation in great perfection, that these characters agree closely with living representatives, that the deposit is a marine one, and the conditions of climate fitting. Taking all this evidence pointing in one direction, I would therefore venture to urge the recognition of my contention that we have here evidence of the existence of an Alga in the secondary rocks of far greater weight than has hitherto been brought forward. The fact that it, like the other fossil Algæ, certainly known to us as such (except the diatoms and Lithothamnion), is a siphoneous Alga may have a certain significance. Owing to the plentiful lack of material, I do not choose to draw any inference from such facts, though others may have a taste for the pastime.

GEorge MurRay.

\section{EXPLANATION OF PLATES.}

Plate IV.

Fig. r. Caulerpa Carruthersii, G. Murr. Nat. size. a. Section near apex.

Fig. 2. a. b. c. Sections seen in cross fracture. Nat. size.

Fig. 3. Ideal figure of $C$. Carruthersii.

Plate V.

Fig. 1. Specimen of C. Carruthersii in Museum of Practical Geology, Jermyn Street. Nat. size.

Fig. 2. a. Caulerpa cactoides Ag. var. gracilis. Nat. size. b. Cross section of C. cactoides ( $\times 15)$. c. Longit. section ( $\times$ I5), after figures by the author in Linn. Soc. Trans. Bot., vol. iii., pt. 4 , plate LII.

- They come slightly to the north of $40^{\circ}$ in the Mediterranean. 


\section{III.}

\section{ON THE STRUCTURE OF DICTYOSPHAEIA $D E C N E$.}

THE genus Dictyospharia, not to be mistaken for the widely different Dictyospharium Naegeli,* was founded by Decaisne, $\dagger$ who took Valonia favulosa, Ag, for the type of it. The commonly accepted view of its systematic position has remained very much the same as that indicated by Decaisne, viz., near Valonia and Anadyomene, and I do not now propose to assign to it any other affinities, but rather to show how strongly this original opinion is confirmed by an investigation of its minute structure and the disclosure of an arrangement of its parts hitherto undescribed.

To the typical species of the genus, Harvey $\ddagger$ added another, $D$. sericea, an exceedingly well-marked species, as will presently be shown, though Harvey himself subsequently seems to have doubted it, $\$$ from an imperfect understanding of its structure. MM. Millardet and Montagne $\|$ added another species, D. Enteromorpha. I have not seen a specimen of this species, and it is very difficult to say from the illustration whether it is to be regarded as a true Dictyospharia or not. Finally, Zanardini added a fourth species, which I have no hesitation in excluding from the genus-on the ground that it is plainly an imperfect Valonia.**

* Einzellige Algen, p. 72.

+ Class. des Algues, Ann. Sci. Nat., 2 sér., vol. xvii., 1842, p. 328.

I Trans. R. Irish Acad., xxii., p. 565, and Fl. Tasm., ii., p. 339, tab. 196 A.

\$ Phycologia Australica, vol. v., Synopsis, p. lix.

II In Maillard, Notes sur l'ile de la Reunion-Algues, p. 4, plate xxv.

T Iconogr. Phycol. Adriat., p. 73, tab. xviii.

** Dr. Schmitz of Greifswald writes in confirmation of this view : ' $D$. valonioides Zan. ist (wie ich durch eigene Untersuchung von Material aus Neapel feststellen konnte) nichts anderes als ein unregelmässiges Regenerationsprodukt eines alten halbzerstörten Exemplares von Valonia macrophysa.' 
The best description known to me of $D$. favulosa is that furnished by Harvey*:-

'Fronds at first globose, like tubers, heaped together, hollow and empty or filled with sea water, attached to the rock and to each other by a few short, rooting processes; at length irregularly torn, and then forming expanded cartilaginous or skinlike, coarsely reticulated membranes. The membrane is wholly composed of a single layer of large globose, or by mutual compression hexagonal cells, which closely adhere by their sides, leaving the convex ends of the cells free, and these form the surface of the membrane, which when dry resembles a piece of fish skin, or a miniature honeycomb. When the cells have been separated, each is seen to be marked at the line of junction by a double row of circular discs. In full-grown cells the primordial utricle is easily separable from the outer cell-wall, and contains a green granular endochrome, from which by cell division four new cells are formed, and thus the frond extends by repeated quadrisection of its component cells. . . . I I have seen hairlike processes issue from it internally, analogous perhaps to the fibrous processes of the membrane of Caulerpa.'

Prof. J. G. Agardh $\dagger$ discusses the structure of Dictyospharia at considerable length, with the general result that he does not carry us much farther than Harvey. I should have said that Kützing $\ddagger$ figures $D$. favulosa, and attributes to the rows of circular discs (noted above) the character of Keimzellen. There was, no doubt, considerable temptation to take this view, having regard to the affinity of Dictyospharia with Valonia. Agardh deals at some length with these discs, pronouncing against the Kützingian view, and, while leaving the matter doubtful, suggesting, 'Forsan credere liceret eadem potissimum analoga esse organis, quæ in membrana aliarum Siphonearum (Espera, Penicillus) conspiciantur, in quibus deposita calcarea magis normaliter coacervantur.' He also discusses the minute processes projecting into the interior of the cells, while also leaving their nature in doubt. With regard to Harvey's idea, he says : 'Vix cum fibris introrsum prominulis Caulerparum eosdem comparare auderem.'

D. favulosa occurs in all tropical seas. I have examined material from Ceylon (Harvey and Ferguson), Mauritius (Pike), Red Sea (Hohenacker), Philippines (Challenger Exp.), Barbadoes (Sir R. Rawson and Miss Watts), St. Thomas (Challenger Exp.), Guadeloupe (Mazé), and Grenada, collected by myself. The specimens of MM. Mazé and Schramm from Guadeloupe called $D$. valonioides $Z a n$. are $D$. favulos $a$. The material principally used is a series of young specimens collected by Ferguson in Ceylon, and my

\footnotetext{
* Nereis Bor. Amt, iii., p. 50, tab. xliv. B.

+ Till. Alg. Syst., viii. (Siphoneæ), p. I13, tab. 2, figs. I-3.

$\ddagger$ Tab. Phyc., Bd. vii., p. Io, tab. xxv.
} 
own specimens preserved in spirit from Grenada. The Ceylon material corresponds with the descriptions of Harvey and Agardh in respect of the hollow interior, while my material shows a solid mass of cells in the young state, the interior cells being less firmly united than the peripheral cells, but ultimately becoming hollow in the older specimens. The first observation was directed to discover the nature of the mysterious discs. These proved to be tenacula emitted from and attached to the cells, and binding the mass together. An inspection of figs. $2 b, c, 3$, will show that these tenacula differ in no essential respect from those already described by Mr. Boodle and myself in Struvea, ${ }^{*}$ Spongocladia, $\dagger$ Microdictyon, $\ddagger$ Boodlea, $\S$ \&c. Where the attachment of the cells is intimate, as in the peripheral cells, the tenacula are short, and in the internal cells, which are more loosely compacted, the tenacula are produced at the ends of filaments (fig. 3) in the familiar manner. The figures exhibit the mode of attachment so well, that a detailed description is unnecessary. After reaching a certain stage of development the tuberous bodies of $D$. favulosa burst, and the lobes appear to go on growing irregularly, giving the mature plant a very different appearance from what it presented in its earlier stages.

With regard to the cell division into four, some of the Ferguson specimens (fig. I $c$, upper part) show what I take to be an appearance of the kind described by Harvey and Agardh, but I am not altogether convinced that the explanation of the matter is so simple. On this point I hesitate to put forward an alternative view for the present. The processes projecting into the interior of the cells (fig. 4) are accurately described by Agardh, and, like him, I fail entirely to apprehend their significance.

We have here, then, in Dictyospharia favulosa one of the simplest forms of valonioid organism, and one, moreover, of some interest from the wider point of view of thallus-formation. Struvea, Boodlea, and Microdictyon present to us examples of a branching reticulate thallus of this type, the component members of which are held together by tenacula; other Siphonocladacea, like Spongocladia and Udotea, show us cases of strands of filaments or fronds similarly connected. Valonia itself, the simplest of these forms, branches, though unpossessed of tenacula for the junction of its members. In Dictyospharia favulosa we have simply an aggregate of similar cells not forming a definite frond, but cohering in an unbranched mass, this colony of units being held together solely by tenacula. It is certainly an extraordinary form of tissue-formation, and represents, it appears to me, the most reduced form of the siphoneous thallus, using the term in the wide Agardhian sense.

* Annals of Botany, vol. ii., No. vii.

‡ Journ. Linn. Soc. Bot., vol. xxv., p. 243.

† Ibid., vol. ii., No. vi.

\$ Ibid. 
Dr. Schmitz, of Greifswald, having heard of my examination of this species, has been good enough to write me the following letter, giving a brief account of his observations on $D$. favulosa. It will be seen that they confirm the above description in certain particulars :-

' Die jungeren Pflanzen von $D$. favulosa sind massive Zellkörper von unregelmässig kugeliger Gestalt, oberseits mehr oder weniger abgeflacht, unterseits etwas verdickt und mit schmaler Insertionsfläche angewachsen. Diese massiven Zellkörper sind grosszellig; die grossen Zellen aber sind angeordnet in unregelmässige verzweigte Zellreihen, die von der Insertionsstelle aus aufwärts fächerförmig auseinanderlaufen. Der ganze Zellkörper aber stellt ein congenital verwachsenes Verzweigungssystem einer grosszelligen Cladophora (z.B. Cl. prolifera) oder einer kleinzelligen Valonia (z.B. V. Cladophora Kütz.) dar, ein Verzweigungssystem, dessen Gliederzellen vielfach secundär querverkettet sind durch ganz kleine HafterZellchen (wie solche ja bei Siphonocladaceen vielfach vorkommen). Nachträglich erfolgt dann in dem stärker verbreiterten Pflanzenkörper unterhalb der obersten Zellenlage der Oberseite die Bildung eines mehr oder minder ausgedehnten horizontalen Spalte, wodurch eine Deckschicht von dem Thallus-körper sich abhebt. Dann reisst die abgehobene Deckschicht in der Mitte unregelmässig auf und reisst von hier aus in wechselnder Weise ein, während sie gleichzeitig unter flächen-Wachstum sich ausdehnt und in verschiedenartigster Weise sich ausbreitet. Eine "Viertheilung" der Zellen erfolgt bei diesem flächen-Wachstum der aufgerissenen Deckschicht aber nicht. Die Lappen der aufgerissenen Deckschicht können dann in mannigfaltigster Weise weitersprossen, häufig auch proliferirenden Sprossungen den Ursprung geben. Fortpflanzungsorgane habe ich nicht beobachtet.'

In Dictyospharia sericea, of which I have examined the material collected by Harvey and Clifton in Australia, we have a more complicated structure. In surface view the thallus presents (fig. 5) a remarkable appearance, not indicated by Harvey either in his figure or description. As figured by Harvey, the thallus is represented simply by a frond consisting of hexagonal cells fitting into each other without intercellular spaces. A minute examination of this view of the thallus discloses the fact, however, that the borders of these cells are everywhere lined with rows of smaller cells-sometimes single, sometimes double rows-running along the tops of the hexagonal walls, and these are discovered to be attached by tenacula (fig. 6 ) alternately on either side. The crosssection (fig. 7) shows the thallus to be several cells thick, with a stratum of large cells in the middle, and two or three above and below it. The bordering cells with tenacula are right over the surfaces of junction, as would be expected, and are here seen to be several in depth above and below, penetrating wedge-fashion between the large cells of the middle stratum. I have said that the thallus is several cells thick, but the view is 
probably equally tenable that the cells immediately overlying and underlying the cells of the middle layer are merely spaces enclosed by membranes separated from the wall of the middle layer by the growth of the bordering cells, and now suspended, as it were, from one border to the other. In favour of this latter view, I should state that I have never seen any cell contents in these overlying and underlying spaces, while those are plentiful, but disorganized, in the cells of the middle layer. Where the section has run along a row of bordering cells, the appearance seen at $a$ (fig. 7) is presented. I account for the appearance at $b$ by supposing that it is an intrusion from the bordering cells, or more probably a cut-off angle from an adjoining cell of the middle layer. Owing to the condition of the material, which required very careful treatment to enable me to obtain this much information, I have been unable to carry the investigation of this species farther. It suffices to show us a form differing very strikingly from the simple $D$. favulosa, and probably confirming the view taken of the affinity of the genus with Anadyomene -a view much shaken by the examination of $D$. favulosa. I have to thank Miss Mitchell for sketches of tenacula in the accompanying plate, and for the interest she has taken in Dictyospharia.

George MurRay.

\section{EXPLANATION OF PLATE VI.}

Fig. I. D. faz'ulosa in various stages of development; $a, c, d, e(\times 2) ; b(\times 8)$; $f$, nat. size; $g$, in section $(\times 3) ; a$ and $b$ represent a plant consisting of a single cell; in $b$, tenacula have already been developed.

Fig. 2. " Cells joined by tenacula, diagrammatic view.

(a) alternate tenacula joining two cell-walls; (b) tenacula seen from below; $(c)$ seen from above $\left(\times \mathrm{r}_{50}\right)$.

Fig. 3. " Tenacula from internal cells-side view ( $x \mathrm{I}_{50} \mathrm{O}$ ).

Fig. 4. " $\quad$ Internal projections from cell-wall $\left(x_{15}{ }^{\circ}\right)$.

Fig. 5. D. sericea, surface view $(\times 66)$.

Fig. 6. $" \quad$ Bordering cells with tenacula $(\times 375)$.

Fig. 7. " $\quad$ Section of thallus $(\times 66)$.

Fig. 8. , Nat. size. 


\section{ON MALFORMATIONS OF ASCOPHYLLUM AND DESMARESTIA.}

IN a short account of the galls in Rhodymenia palmata Grev., published in the Journal of Botany for March, I89I, I referred to malformations found in Ascophyllum nodosum which were shown me by Mr. George Murray, having been collected by him at Stonehaven. During a visit to Cumbræ last summer I found a number of Ascoplyyllum plants bearing similar growths, and in one instance almost every branch of the thallus was more or less affected. I collected specimens both from this plant and from others near it, and preserved them for investigation in London and for comparison with those I had already seen.

The malformations are almost invariably confined to the part of the thallus immediately above or below the air-vesicles, and in many cases the thallus is broken away across the middle of a vesicle, the remaining half being transformed into a solid mass of diseased tissue. On the younger vesicles the swellings are considerably smaller than on those nearer the base of the thallus, probably from having been more recently attacked. The thallus in the affected parts is much swollen and covered with small, round swellings or lumps, forming a corrugated surface (plate vir., figs. I and 2); and a transverse section through this part shows that each lump is a more or less hollow space containing numerous nematode worms (plate vir., fig. 3). In the younger stages of the disease the central part of the tissue is not affected, and the cavities are not in communication with one another; but in the older stages the whole of the tissue of the affected part becomes diseased, and the partitions between the cavities are broken down, both cavity and passage being bordered by a thick wall of disorganized tissue closely pressed together. The cavities are flask-shaped and have a small narrow opening at the top, by which the nematodes appear to make their way in or out. In the youngest stages of malformations that I have found, a slight rupture of 
the epidermal layer and a forcing asunder of the tissue beneath is observed (plate vir., fig. 4), caused probably by the entrance of the nematode from without; and the space thus made is filled with a granular substance, in which I believe I have found parts of the animal cut through. It is difficult, however, to find the nematode in the young galls, as the cross sections of the cells of the thallus bear much superficial resemblance in outline to similar sections of the animals. The effect of this forcible entrance of the nematode appears to be that the thallus swells up all round the spot inhabited by the animal, probably caused, like gall structures in general, by the stimulation of some animal secretion. I have in no case found any communication between the galls along the interior of the thallus, and I am therefore forced to believe that the nematode attacks each affected spot separately and from outside.

The material of Ascophyllum nodosum collected at Stonehaven shows the same hollows filled with nematodes, and, as these growths appear to be rather common, I imagine that Ascophyllum is a favourite resort of this species of worm. I have in no instance found these malformations inhabited by any other sort of animal, and only by nematodes in a fully grown condition.

As regards the nematode itself, I have sent specimens of it to Dr. de Man, of Middelburg, who has very kindly examined them, and pronounces the species to be new to science. We have therefore called it Tylenchus fucicolus, $n . s p$, and a detailed description of it with plates will shortly be published by Dr. de Man, to whom I here offer my best thanks for the interest he has taken in this investigation.

I also wish to express my indebtedness to Professor King for the trouble he has taken in sending me fresh material from time to time, and for the interest he has shown in the work.

Through the kindness of Mr. Batters, I have been enabled to examine malformations on Desmarcstia aculeata, Lam., found by him on the island of Cumbræ in September of last year. The malformations in this Alga are small round bodies, sometimes growing singly on a young part of the thallus, sometimes grouped together on the thick stem, forming a slightly raised ridge about a quarter of an inch long. In other places a lump is formed in the angle of the branches, in shape somewhat like the young malformations on Ascophyllum nodosum, described above; and it is in these lumps that there is the greatest likelihood of finding the animal which causes this growth, viz., a copepod.

A vertical section through one of these swellings, transverse to the thallus, shows that the hypertrophied tissue is composed of very closely interwoven anastomosing hyphæ, which somewhat resemble the ordinary 
pseudo-cortex of Desmarestia, as seen in longitudinal section (fig. 5). The walls are generally thinner, however, and the cells much smaller than the normal tissue. The cells are very full of contents, and the dark yellow mucilage, as well as the granular substance, which I found in Rhodymenia palmata, are here in abundance. The Rhodymenia galls, it may be remembered, were also caused by a copepod, Harpacticus chelifer. In some cases the tissue is torn, and an opening communicates with the outside, looking as if some animal had forced its way through the cells into the open. The space is always half filled with the fine granular matter mentioned above, and the cells bordering it are very small and thin-walled, showing that some reparative process has been going on around the torn cells. In cutting open some of the larger swellings, a quantity of oblong brown cells pour out, sometimes separate, sometimes adhering together; and, in nearly every case where these brown cells are, there may be found a specimen of the copepod which causes the outgrowths. I cannot in any way account for the fact that, notwithstanding the large number of outgrowths examined, I have found so few copepoda-indeed, in the whole investigation, I have only succeeded in teasing out one fully developed specimen, the others being all rolled up in a more or less immature condition.

In the case of Rhodymenia palmata, I took the view that the copepod went through its various stages of development in the thallus of the Alga, and on reaching maturity it forced its way out into the open. This view was strongly opposed by an authority on Crustacea, and, until the eggs of the animal are found in the youngest outgrowths, it is impossible that this idea can be more than a theory; but, if it is incorrect, I cannot understand how the animal comes to be found in the outgrowths before it is fully developed and while still in the nauplius state.

In Rhodymenia palmata, the small galls in which the tissue was quite undisturbed were probably caused by irritation, which had spread over the adjoining area round the invaded spot of the Alga, and in the case of Desmarestia I account for the presence of the small outgrowths of undisturbed tissue near the nidus of the copepod in the same way. The isolated swellings, however, on the young branches of the thallus must be formed singly by a puncture or other invasion, as they are too far away in many cases from the scene of disturbance to be accounted for on the score of irritation. Their structure is the same as that of the larger swellings (plate viI., fig. 6), and many of the cells contain darkly coloured matter.

I have sent specimens of the copepoda, teased out from the mature outgrowths, to Dr. G. S. Brady, who was so kind as to interest himself in 
my former investigation; but, unfortunately, he has not been able to decide the name of the species, through want of a sufficient number of complete specimens, most of those I sent to him being immature. I hope, therefore, when I shall have the opportunity of collecting fresh material, to send more specimens to Dr. Brady, that the question as to the species of copepod may be settled.

Finally, I must express my gratitude to him for the very kind help and encouragement he always gives me.

Ethel S. BARTon.

\section{EXPLANATION OF PLATE VII.}

Ascophyllum nodosum.

x. Malformation. Natural size.

2. ", Trans. sect. $(\times 4)$.

3. " Mature $(\times 66)$.

4. $\quad$ Young $(\times 66)$.

Desmarestia nculeata Lam.

5. Vertical section of malformation ( $\left.x_{143}\right)$.

6 . " " small outgrowth $(\times 37)$. 


\section{V. \\ ON CONCHOCELIS, A NEW GENUS OF PERFORATING ALGAE.}

IN their interesting account of the plants living in the calcareous shells of molluscs, MM. Bornet and Flahault* mention eight genera of Algæ which may be met with in this strange situation. All of these genera are members either of the Cyanophycee or Chlorophycee, and are either bluish or purplish green or grass-green in colour. It was therefore with both surprise and pleasure that I detected among some perforating Algæ, extracted from shells which I had gathered near Cumbræ, in the Clyde sea area, some filaments of a beautiful carmine-coloured Alga belonging apparently to the Porphyracee. As Dr. Bornet had devoted so much time and attention to the subject of the perforating Algæ, I sent the specimen to him, requesting him to let me know if, during his researches, he had met with anything similar. He at once replied that he had not previously seen anything resembling my plant, which he believed to be a new Alga related to Erythrotrichia. I propose in the present paper to give a short account of this interesting addition to our marine flora.

The shells from which this Alga was first obtained were dredged from 6-8 fathoms water off the Tan buoy, between the islands of Great and Little Cumbræ. The best specimens were got in the empty shells of Mya truncata and Solen vagina (the common razor-shell). I have, however, subsequently found the same plant, though in poor condition, in many other shells left on the sandy beach by the receding tide.

To the naked eye the presence of the Alga is betrayed by a pink stain, which cannot be removed by rubbing, on the inner surface of the shells. If a flake, sufficiently thin to be semi-transparent, be broken from

* 'Sur quelques plants vivant dans le test calcaire des mollusques, par MM. Ed. Bornet et Ch. Flahault.'-Bulletin de la Société botanique de France, vol. xxxvi. 
a shell which contains Conchocelis, it is an easy matter, even with a pocket lens, to see the delicate pink radiating filaments of the Alga. It is not however, till the plant has been freed from the calcareous substance in which it grows that its characters can be made out in a satisfactory way. I have found that the best decalcifying agent is the 'liquide de Pérényi'the formula for which is given by MM. Bornet and Flahault, which, though it acts slowly, is much more satisfactory in its results than any other solution I have tried. At first the Alga appears in the form of roundish spots, which finally become confluent, their pink colour sharply distinguishing them from the spots formed by any of the other perforating Algæ which always, or at least very frequently, accompany them.

On removing the Alga from the shell by means of the 'liquide de Pérényi,' one at once perceives that these spots are formed of a network of interlaced branching filaments, the central portion of the patch being so closely felted together that it is impossible to make out the ramifications of the filaments; but at the edges the filaments are not so closely interlaced, and it is easy to trace any particular thread for a considerable portion of its length.

The thallus is formed of articulated branched filaments, which in the young plants (figs. I and 2) radiate more or less from a central point. Later, by the confluence of several groups, and the consequent interlacing of their filaments, a more or less compact, continuous, horizontal network (fig. 3), which finally covers a considerable portion of the shell, is formed in the superficial layer of the shell. These filaments are of very various widths; the most slender that I have measured was only $I \cdot 5 \mu$ in diameter, while the most robust was $7 \cdot 5 \mu$, the usual width being about $4 \mu$. The cells of which the horizontal filaments are composed are of very various shapes - straight or curved, clavate or triangular, or so irregular as to defy description. Below the horizontal layer the filaments swell out here and there into irregularly shaped, septate, simple, or slightly branched inflations (fig. 5), which are, of course, much more robust than the ordinary filaments; they are often $20-30 \mu$ in diameter, though they seldom reach more than from 70-I IO $\mu$ in length. The branching of the ordinary filaments is very irregular; sometimes for a considerable space a filament is quite simple, and then suddenly, by the outgrowth of lateral shoots, becomes densely branched. The lateral branches are either opposite or alternate, and are either simple or more frequently rebranched, their lateral shoots sometimes anastomosing. The cells of these filaments and those of the inflations are always more or less constricted at the joints.

The inflations (Fig. 5), which usually consist of from two to ten 
cells, varying in length from $\mathrm{I} 5-30 \mu$, are either quite simple or more or less branched. In the centre of each cell of the inflations there is a star-shaped chromatophore, the rays of which often reach to the edges of the cell. I have been unable to detect with any degree of certainty the manner in which the colouring matter is disposed in the ordinary filaments, but it appears to be applied in a continuous layer to the walls of the tubes, which are always, so far as I have observed, of a uniform, or nearly uniform, carmine colour. The inflations often become detached from the horizontal filaments, and are then capable of an independent existence. I have frequently found these inflations of all sizes and shapes, growing in company with Gomontia and other perforating Algæ, but without any trace of the horizontal filaments of the Conchocelis from which they have originated.

The plant appears to be reproduced by means of spores formed in the cells of the inflations, one spore in each cell. I have seen globular bodies which appear to be spores escape from the cells, and not unfrequently one sees them lying free among the filaments of other perforating Algæ.

The shape and colour of the chromatophores, and the manner in which the spores are formed, point to a strong relationship between Erythrotrichia and the present genus; but the branched frond and curious inflations sharply separate the genera. In some respects, e.g., the inflations and the branching, Conchocelis resembles Ostreobium, from which it is at once distinguishable by its pink colour and articulated filaments.

Conchocelis nov. gen.-Thallus minutus e filis ramosis articulatis hic illic in utriculos septatos, forma irregulari dilatantibus, compositus. Propagatio fit per sporas in cellulis utriculorum evolutas. Unica spora in singulis cellulis. Genus ad Porphyraceas referendum.

Conchocelis rosea, n. sp., thallo immerso, roseo, maculas orbiculares demum confluentes et ambitu indefinitas efficiente; filis primariis in stratum pannosum implicatis, ex cellulis cylindraceis, tortuosis aut forma irregulari, 7 usque ad $75 \mu$ et ultra longis $I^{\cdot} 5-7$, sæpius $4-5 \mu$ crassis constantibus. Utriculis simplicibus aut ramosis usque ad I I $\mu$ longis ad $30 \mu$ latis. Sporis globosis $\mathrm{I} 3-15 \mu$ crassis.

Hab. in conchis vetustis sæpe in consortio Gomontice ad oras Scotiæ prope Millport in insula Cumbræ.

Edw. A. Batters. 


\section{EXPLANATION OF PLATE VIII.}

Prepared from specimens decalcified by Pérényi's solution.

Figs. I and 2. Young plants taken from a part of the shell very little attacked by the Alga ( $\times 250$ ).

Fig. 3. Portion of the horizontal network at a more advanced period $(\times 250)$.

Fig. 4. Portion of the vertical filaments $(\times 250)$.

Fig. 5. Various stages in the development of the inflations, showing the chromatophores.

Fig. 6. Portion of an inflation with spores. 


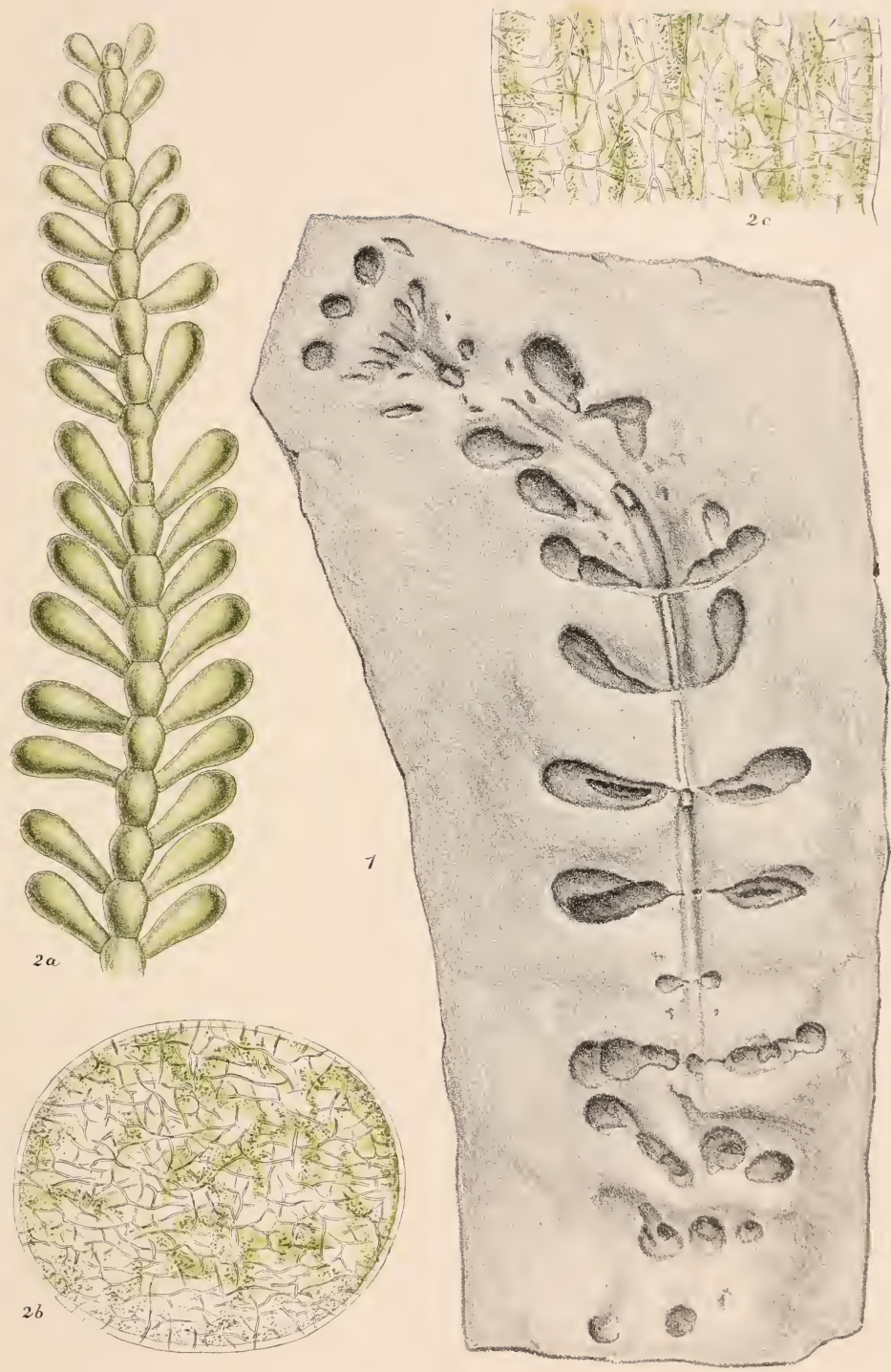




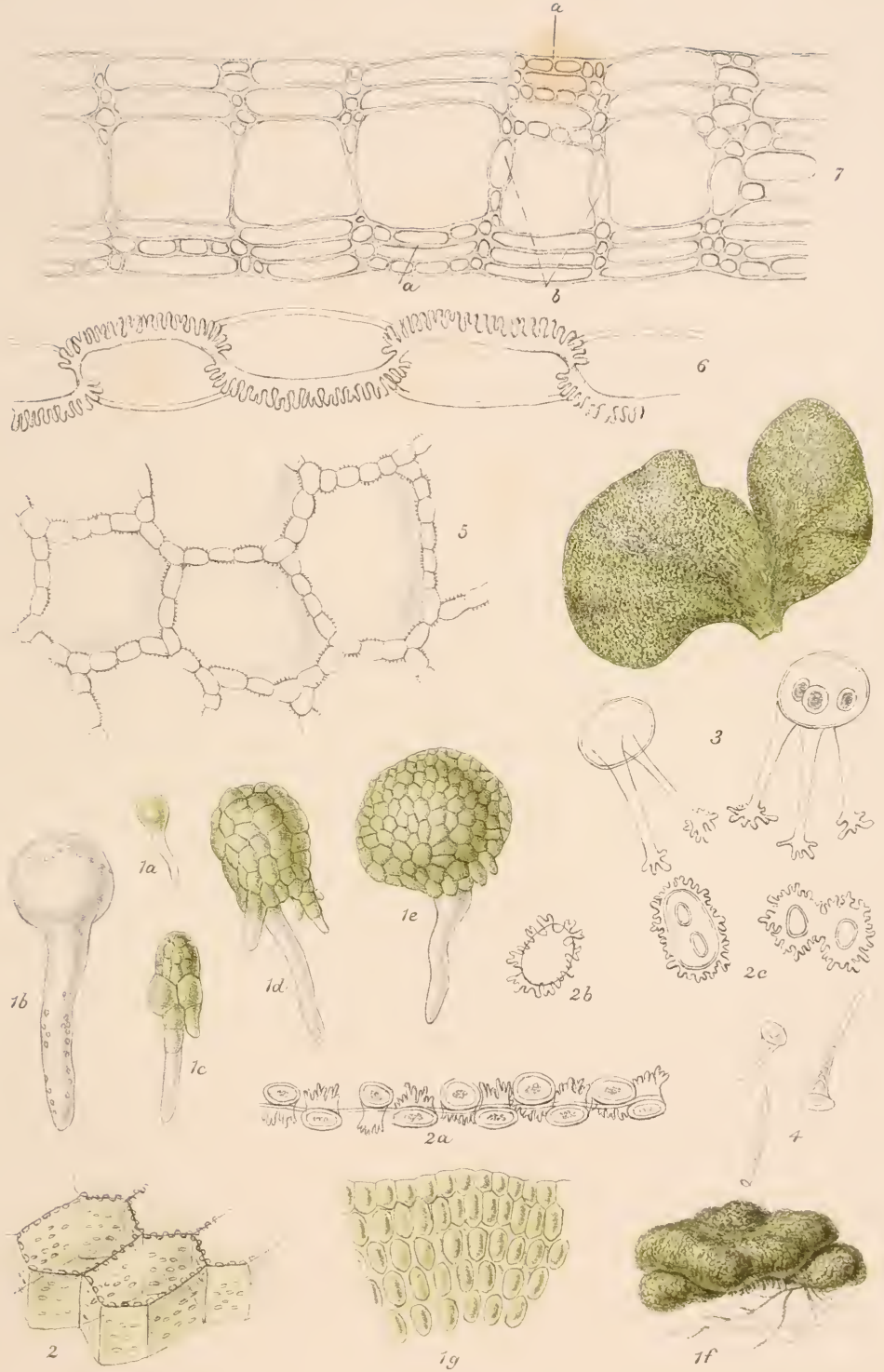


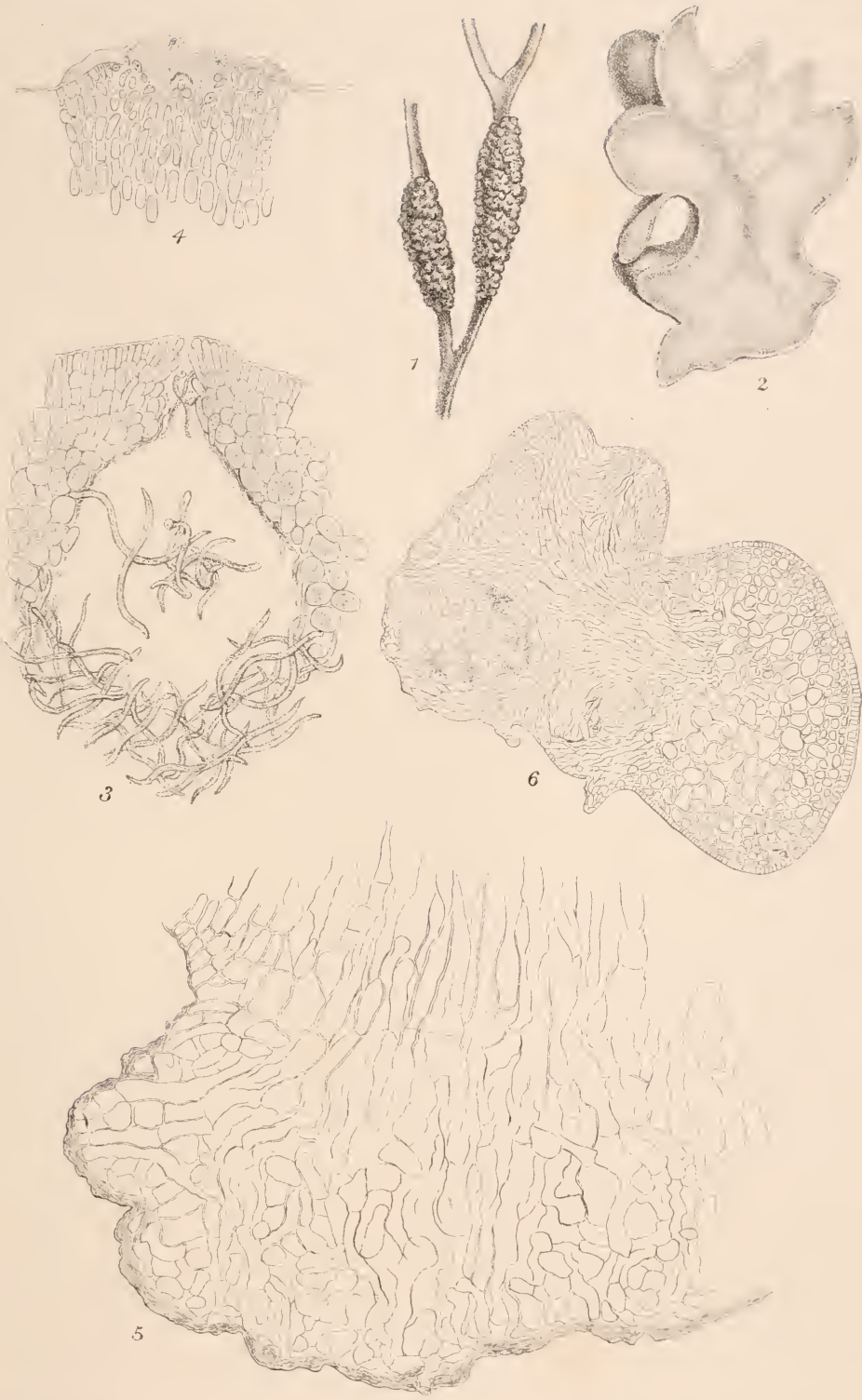

Fhyc Mem Ela: :
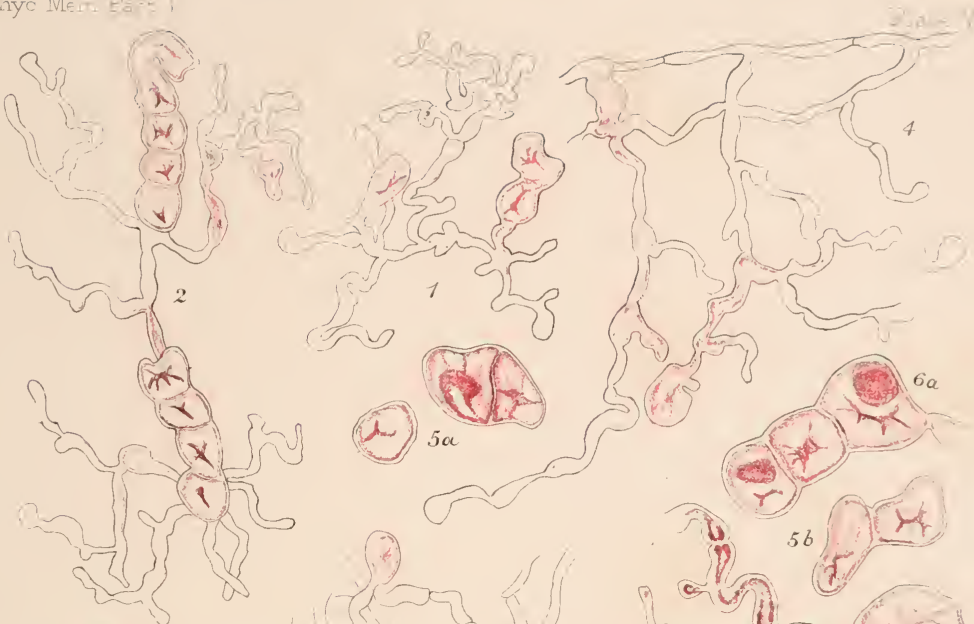

in

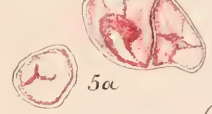

(7)
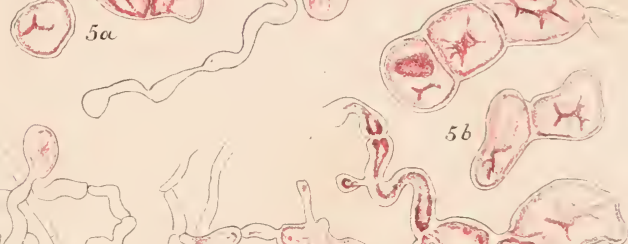

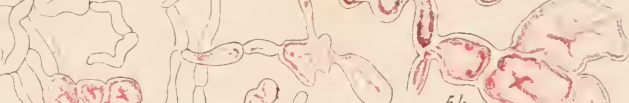
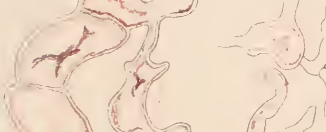

d)
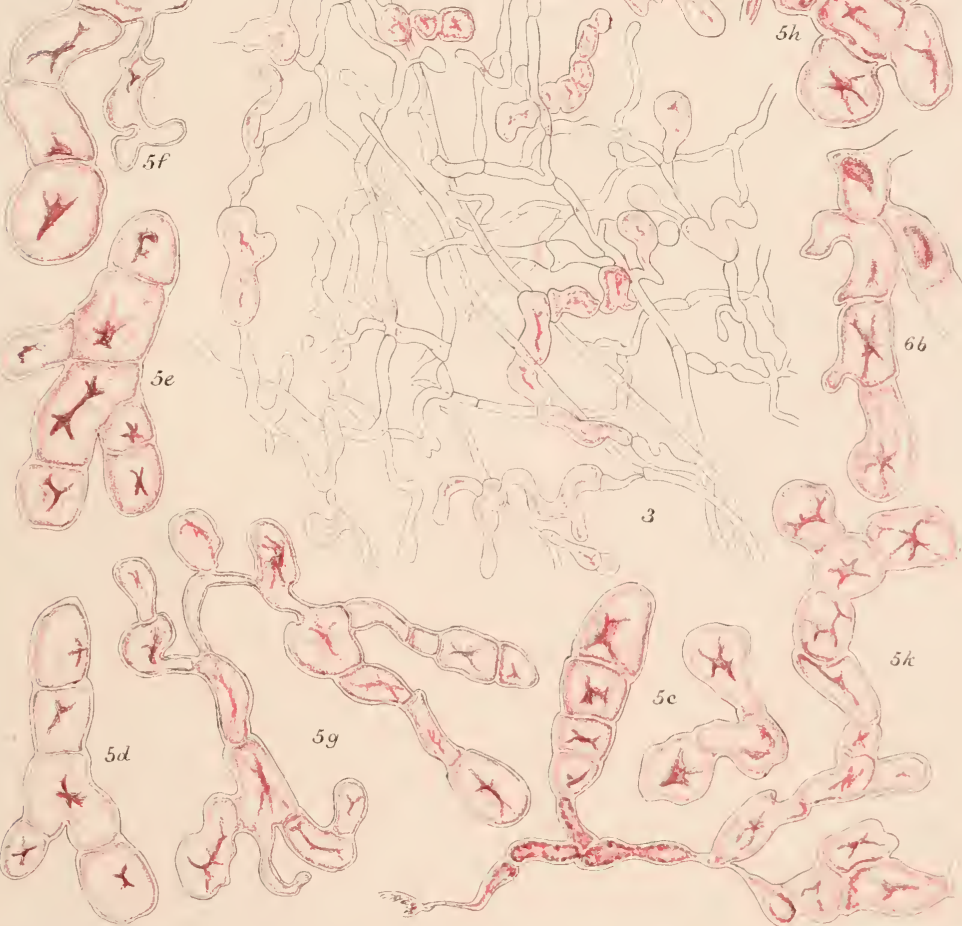

(*)
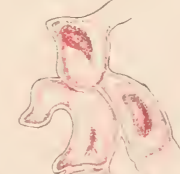

1 Sont?

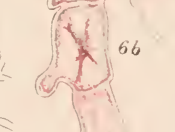





\section{NOTES ON THE MORPHOLOGY OF THE FUCACEA.}

THE object of these notes is to supply deficiencies in the account of the Fucacee given by Oltmanns,* by a study of those types which he was unable to examine or of which he had imperfect material. In his grouping of the genera marks of uncertainty are attached to Coccophora, Xiphophora, Sarcophycus, Myriodesma, Ecklonia, Scaberia, Hormosira, and Splachnidium. The first three of these genera are dealt with below, together with Seirococcus and Notheia, which I thought worth more minute examination. Myriodesina has been examined, with the result that the position assigned to it by Oltmanns is confirmed, and his query may be removed. Of Ecklonia and Scaberia satisfactory material did not arrive in time for inclusion in this research, and an account of them will appear later. Hormosira had already been dealt with by Mr. Mollet $\dagger$ (overlooked by Oltmanns) and Splachnidium was accounted for in the first part of these Memoirs. With regard to this last genus, now excluded from the Fucacee, it is gratifying to receive the following confirmation in an essential point of the interpretation of the structure, by Mr. R. M. Laing, whose previous work at Splachnidium has been referred to. He writes to the authors from Christchurch, New Zealand, on the 15 th February of this year: 'I am glad to say that I am able to bear out the conclusions you arrived at as to the nature of the supposed oogonia, as several years ago I saw zoospores in active motion escape from some that $I$ had been examining,

* Bibliothecar Botanica, Heft 14, 1889.

$\dagger$ On the Structure of Hormosira Labillardicri (Trans. New Zcaland Institute, vol. xiii., I880). 
confirming your conclusions as to their real nature. I have written a note on the subject for the Transactions of the New Zealand Institute,' etc.

With regard to the other genera named, excepting the two reserved for the present, the general result is that, with regard to Seirococcus and Coccophora, Oltmanns' expectations are confirmed as to their oogonia and the number of their oospores. Xipleophora, on the other hand, yields four oospores in each oogonium instead of one, as conjectured by Oltmanns. It had better, therefore, be removed from his section Loriformes and be placed in the Fncece with Ascophyllmm, though its receptacle bears a remarkable likeness to Himanthalia, the type of Loriformes. Notheia was not included in Oltmanns' review of genera. The result of this examination would point to its true position in the section Fucee as a very degenerate member. Hormosira is also in the same section, judging by Mr. Mollet's observations (confirmed by Miss Smith).

Sarcophycus, which has four oospores in each oogonium, is so plainly the ally of Durvillea that it may remain with it and Ecklonia pending the further investigation of these genera. It may be noted that, though the four oospores suggest affinity with the Fncee in this respect, yet the different form of their segmentation described by Miss Whitting, and the frequent situation of the oogonia on branching hairs afford characters that may be looked for in its companion genera.

Oltmanns appears to me to attach undue weight, in estimating those characters on which he rests his sections, to that afforded by the growth of the plants, viz., the occurrence of three or four-sided apical cells. My reason for depreciating the value of such a character is its proved inconstancy, not only among Algx, but even in the much less plastic forms of the Vascular Cryptogams.

Hearty thanks for material of Seirococcns, Iiphophora, Hormosira, Notheia, and Sarcophycus are due to Mr. Bracebridge Wilson, of Geelong, Australia.

\section{COCCOPHORA LANGSDORFII GREV.}

DAWSON TURNER gives us the first account of this beautiful and uncommon sea-weed in his Finci, vol. iii., p. 76, tab. 165.

It was brought to him from Japan, as a dried specimen, by Dr. Langsdorff, the 'natural Philosopher' attached to a Russian expedition round the world. 
Dr. Langsdorff gave him at the same time a drawing of the plant in its natural condition by Prof. Mertens, which Turner incorporated along with the description of the new plant, and named it Fucus Langsdorfii in honour of its finder.

Tilesius, a companion of Dr. Langsdorff on this expedition, also gathered and brought home a specimen which he gave to C. Agardh. A preliminary description of it under the name of Fucus Tilesii, was published by Agardh in I8I2. (Alg. Dec. I.)

In his Species Algarmm, p. 78 (I 823), he described the plant more fully and transferred it to the genus Cystoscira.

Finally, in I830, Greville founded for it a new genus, Coccophora (Synopsis, p. 34), retaining Turner's specific name Langsdorfii.

The specimen in the British Museum is from the Shuttleworth Herbarium, dated 1830 . The plant bears out the description given by Turner, being of a dull black colour in the dry condition.

Coccophora Langsdorfii is one of the most highly organized of the Fuci, recalling Sargassum with its leaves and berries. It has a central axis or stem from which lateral members are given off, according to Turner: 'alternate and separated by intervals of an inch, or standing close together, and not uncommonly two or three rising together from the same point, about half a foot long, and each swollen at its base into a small bulb.' This latter statement I have been unable to verify.

These branches from the main stem (plate IX., fig. I) are spirally clothed with short, sessile, entire, tapering leaves, which, towards the apex, are replaced by a raceme of berry-like hollow receptacles, each borne on a short stalk. This transformation of leaves into special organs for fruit-bearing divides Coccophora from the Cystoseira, and places it in another group between Cystophora and Scaberia.

The vegetative tissue is very simple. There is a central cylinder of long empty cells, with very small lumen, owing to the great thickness of the cell-wall. Towards the outside the cells are shorter and broader with thinner walls, thus forming a sort of cortex, and the epidermis is of brick-shaped cells. This layer and the outer cortical cells are filled with dark brown contents (plate IX., figs. 3 and 4).

The tissue of the leaves is continuous with that of the main axis; there is a middle strand of long thick-walled cells and wings of large rectangular or polygonal cells, clothed with an epidermis similar to that of the stem.

The hollow receptacles have an uniform tissue of comparatively thick. walled cortical cells, which are richer in contents than those of the vegetative tissue. The conceptacles are numerous and crowded, and are 
separated from each other by a narrow strand of tissue (plate IX., fig. 2).

The plants examined by me are dicecious. The male conceptacles do not differ from those of other Fuci; the female conceptacles are full of oogonia, with multicellular hairs interspersed among them.

The oogonium rises on a broad base from the wall of the conceptacle, one division cutting off the large solitary oosphere from the pedicel which is buried in the wall of the conceptacle, and probably therefore resembles that of Pelvetia, where the pedicel cell is short, and does not elongate to form a stalk.

\section{A. Lorrain Smith.}

\section{EXPLANATION OF PLATE IX.}

Fig. I. Coccophora Langsdnrfii. Natural size.

Fig. 2. Receptacle enlarged $(\times 5)$.

Fig. 3. Longitudinal section of branch and base of leaf $\left(x_{15} \mathrm{c}\right)$.

Fig. 4. Transverse section of stem $\left(x_{1} 5^{\circ}\right)$.

Fig. 5. Male conceptacle $\left(\times \mathrm{I}_{50}\right.$ )

Fig. 6. Antheridia $\left(\times 45^{\circ}\right)$.

Fig. 7. Female conceptacle ( $x_{150}$ ).

\section{SEIROCOCCUS AXILI.ARIS GREV.}

This Alga was found at Port Dalrymple by Robert Brown during his expedition to New Holland at the beginning of the century. $\mathrm{He}$ named it Fucus axillaris, and under that name placed it in the Herb. Brit. Mus. In his MS. it is thus described: 'Fucus fronde plana ramosissima ramis ramulisque alternis, integris, coriaceus aveneis siliquis marginalibus confertis pedicellatis torulosis. Inter rejectimenta maris, Port Dalrymple.'

He communicated specimens to Dawson Turner, who, in his Fuci, vol. iii., p. 28, tab. 146, figured and described it under Brown's name. Turner referred Mertens' Fucus scorteus (Mertens MS. fide D. T.) to this species as Var. $\beta$; but, from an examination of the series in the 
British Museum, I am satisfied that it does not deserve to be separated from the species even as a variety.

Agardh, in his Systema, p. 29I, places this Alga among the Cystoseirae, and in his Species Algarum he repeats this determination, and names it Cystoseira axillaris.

The genus Seirococcus was created by Greville for this plant, of which it is the only known species. (Symopsis, p. 34.)

Montagne, in Dumont D'Urville's Voy'age au Pole Sud (Botanique, vol. i., p. 86, I845), discussing the systematic position of Seirococcus, refuses to accept it as a separate genus, and insists on its resemblance to Scytothalia, under which he places it. The receptacular branch he allowed was different, but did not think it of importance.

Kützing records it as Scytothalia axillaris (Species Algarum, p. 592), and Oltmanns* seems doubtfully to follow him.

I have adhered to Greville's classification for the following reasons. There is an undoubted resemblance between the two plants in their structure and mode of growth which makes them very closely allied, but the receptacular branches differ from each other in a marked degree. Harvey, who agrees with the Grevillean classification, adds another slight distinction (Phycologia Australica, plate IV.), 'Scytothalia when steeped in fresh water throws out, like Fucus, an immense quantity of slimy gelatine ; but this is not the case with Seirococcus.' On examination I find the cells of Scytothalia have very much swollen mucilaginous walls. The conceptacles of Seirococcus are borne on special branches, not on metamorphosed organs like those of Coccophora and some other Fuci. It is this rather striking peculiarity which separates it from the Cystoseirae, the affinity with which Turner had already questioned, and places it near the Sargassea. Oltmanns, in his arrangement of the Fucacea, places it under that group, and the following details of its structure confirm his judgment.

The plant has a flat stem from which side branches are given off irregularly (plate x., fig. J.) These branches bear the flat sinuous fronds which rise alternately at an acute angle. On the opposite edge from the leaf insertion there is a narrow wing, which in turn broadens out to form a frond. The fronds are simple and entire, flat and rather sinuous; there is no midrib, and they vary in width, tapering to a blunt tip, simple or bifid.

The plant has much the same structure throughout, in stem and frond. There is a central portion in the stem of long cells with very much thickened walls; a cortex of larger looser cells, and an epidermis several 
layers deep of small brick-shaped cells very rich in contents. In the frond the same structure is repeated (plate X., figs. 3 and 4), but the central thick strand has been flattened out and stretches across the frond, giving it a leathery consistence. The cortex and epidermis are not so strongly developed.

The fruit-branches or receptacles are erect and torulose (plate $\mathrm{x}$., figs. I and 2); they occur along the axils formed by the frond and the wing of the stem. They vary in size and are crowded together, some rising directly from the leaf margin; others are borne on a flat or round pedicel, and branch irregularly. Each swelling of the receptacular branch encloses a diclinous conceptacle. The male conceptacles as a rule are at the base of the fruit-branch, the female nearer the top, and both occur on the same branch.

The antheridia in the male conceptacles are much branched, and are accompanied by the usual branching paraphyses (plate X., figs. 5 and 6.) The female conceptacles are crowded with oogonia. There is only one oosphere cut off from the base of the oogonium (plate x., fig. 8), and the pedicel cell, if present, is obscure. The paraphyses are large with irregular cells rich in protoplasm and having a marked tendency to branch (plate X., fig. 9). Harvey states that Seirococcus occurs only at Tasmania and on the south coast of Australia, and not further west than Cape Northumberland. I find a record of it in the Herb. Mus. Brit. as far north as Cape York in Torres Straits, well within the tropics.

The specimen I have examined was collected last year at Geelong, by Mr. Bracebridge Wilson.

A. Lorrain Smith.

\section{EXPLANATION OF PLATE X.}

Fig. I. Seirococcus axillaris, part of plant. Natural size.

Fig. 2. Part of frond with receptacular branch. Slightly enlarged.

Fig. 3. Transverse section of frond $\left(x_{15} 0\right)$.

Fig. 4. Longitudinal section of frond $\left(x \mathrm{I}_{50}\right)$.

Fig. 5. Section through male conceptacle $\left(x \mathrm{I}_{50} \mathrm{O}\right)$.

Fig. 6. Antheridial branch $\left(\times 45^{\circ}\right)$.

Fig. 7. Section through female conceptacle $\left(x_{150}\right)$.

Fig. 8. Oogonium (225).

Fig. 9. Paraphyses of female conceptacle $(\times 225)$. 


\section{XIPHOPHORA BILLARDIERII MONT.}

THE earliest description of Yiphophora Billardierii is by Labillardière under the name of Fucus gladiatus (Pl. Nov. Holl., ii., p. III, t. 256), but neither here nor in the description of the plant in Turner's Fuci (vol. iv., p. IO2) is there any definite account of the structure. The first detailed examination of the fruits was made by Montagne and described by him in the Annales des Sciences naturelles, sér. 2, vol. xviii., p. 200 , where he founds the genus Xiphophora. In the same place he dwells at some length on his theory that the antheridia of the Fucacece are possibly homologous with the tetraspores of the Floridea, a theory which other botanists of the time seemed to favour.

In I860, Harvey added to the genus Yiphophora the Fincus cliondropliyllus of $\mathrm{R}$. Brown, the type specimen of which, preserved in the British Museum, bears on the label 'cf. Fucus gladiatns,' in R. Brown's handwriting, showing that he recognised the relationship of the two species. Since an authentic specimen of Fucus gladiatus named by Labillardière himself is also in the British Museum, I have been able to compare the other specimens in the Herbarium with the types of both species; there are, however, many intermediate forms, showing Fucus gladiatus with comparatively short receptacles, approaching more nearly to the short, dichotomous branches of Fucus chondrophyllus. Agardh in his Spec. gen. et ord. Alg., vol. i., amalgamates the genera Xiphophora, Pycuophycus, Ozothallia and Pelvetia, and forms of them all a new genus Fucodium, merely reserving the former generic names for sections in that genus. I have, however, followed the example of Oltmanns and others, and retained Montagne's generic name of Xiphophor .

This genus is confined to the southern hemisphere, where it is found on the shores of Australia, Tasmania, New Zealand and the Auckland Islands; both species appear to be common.

I have examined material of Yiphophora Billardierii preserved in the British Museum Herbarium from Lyall's Bay, New Zealand, collected by Dr. Lyall ; from New Zealand, collected by the Antarctic Expedition ; and a plant, preserved in spirit, sent from Geelong, by Mr. Bracebridge Wilson.

Xiphophora Billardierii Mont. is, as its generic name implies, a plant bearing long, sword-like branches, and these constitute the receptacles, while the vegetative part of the thallus is shortly dichotomous. But, although the generic name characterises the species which the genus was originally 
formed to receive, the same cannot be said of $X$. chondrophyllus Harv. Its main point of difference from $X$. Billardierii consists in the entire absence of the long strap-shaped laciniæ, all the branches of the thallus ending in short dichotomous forks, which form the receptacles. It will therefore be necessary to modify Montagne's generic description of the receptacles if $X$. chondrophyllus is to be retained in the genus. Oltmanns (Beiträge zur Kenntniss der Fucaceen, p. 69) points out an external likeness between Xiphophora and Himanthalia, which, however, only extends to both plants having the long receptacles; and even these, as mentioned above, are often in Xiphophora very much reduced.

The thallus is composed of three layers of cells : the cortex, consisting of one row of narrow radiating cells, the parenchyma below the cortex, and a central strand of long, narrow cells with thick longitudinal and very delicate transverse walls. The thick longitudinal walls are marked at intervals by thin places resembling pits, as in the central strand of Turbinaria; but, the material at my command not being fresh, I have been unable to detect continuity of protoplasm. Oltmanns (loc. cit., p. 70) queries the number of oospores in an oogonium as $\mathrm{I}$; but, on examining a large number of conceptacles, I find each oogonium contains four oospores divided tetrahedrally as in Ascophyllum. So far as I can see, in dried material the oogonia have no pedicel cell, but grow directly from the cells at the base of the conceptacle. Both species of this genus are monœcious.

E. S. BARTON.

$$
\text { (For explanation of figures see p. 37.) }
$$

NOTHEIA ANOMOLA BAIL. and HARV.

EXCEPT a short account of it in the Transactions of the New Zealand Institute (vol. xviii., I885), by Mr. R. M. Laing, I know of no adequate description of Notheic anomola. The remarkable structure of the plant led me to make a further examination of it. This so far has shown that there are points of great interest waiting solution, but with the material at my command I have been unable to make a detailed investigation of the plant, and can only therefore give a preliminary note on the subject at the present time.

The points which appear to me of interest, and worthy of further investigation, are :- 
I. The parasitic habit of the plant.- $U p$ to the present time but few truly parasitic Algæ have been recorded. Notheia anomola grows vigorously on Hormosira and Fucodium.

A longitudinal section of the junction of the Notheia and Hormosira, when stained with methylene blue, shows that the cells of the thallus of Hormosira stain a deep blue, as also do the outer layers of cells of Notheia, but that the central cells of Notheia, and a wedge-shaped mass of tissue, which penetrates the thallus of the host, remain unstained. The appearance of the cell-contents and the cell-walls in the neighbourhood of the wedge is suggestive of tissue in a state of degeneration; but it is impossible to say anything decisive on this point unless fresh tissues are examined.

2. The production of the lateral branches.-Each branch rises from the base of a conceptacle, even though this be filled with hairs and reproductive organs.

3. The presence of one kind of sexual reproductive organ.-The reproductive organs are developed in well-formed conceptacles. In the latter, hairs are present at a very young stage; they appear to grow only from the base at first, and stand up parallel to one another and perpendicularly to the base; other hairs appear later, growing from the sides, among which the reproductive organs are developed.

The reproductive organs have every appearance of oogonia, but no antheridia have ever been recorded, and I have examined many plants for them in vain. The accounts of the number of the oospheres have differed in various records, but I have invariably found eight present, generally arranged in the same manner, that is, one oosphere at either end of the oogonium, the remaining six in the centre in two groups of three oospheres each.

MARGaReT O. Mitchell.

\section{EXPLANATION OF PLATE XI.}

Fig. I. Male conceptacle of Xiphophora Billardierii Mont. ( $\times 66)$.

Fig. 2. Antheridia ( $x 375)$.

Fig. 3. Female conceptacle $(x 66)$.

Fig. 4. Oogonium ( $x$ I 90 ).

Fig. 5. Notheia growing on Hormosira (a), and Fucodium (b). Nat. size.

Fig. 6. " Diagrammatic section of the thallus to show the origin of a lateral branch from a conceptacle containing oogonia $(\times 250)$.

Fig. 7. " Oogonium $\left(\times 25^{\circ}\right)$.

Fig. 8. " " Section of the junction of Homosira and Notheia: the cells with darker contents represent those stained with methylene blue; the other cells are unstained $\left(\times 25^{\circ}\right)$. 


\section{SARCOPHYCUS POTATORUM KÜTZ.}

THE earliest record of this plant is a description and figure of Fucus potatorum in 1806 by Labillardière, ${ }^{*}$ who assigned to it the specific name potatorum in consequence of having observed the natives of the woods round Van Diemen's Land use portions of its great fronds, folded in the form of a pouch, for the purpose of keeping fresh water. Dawson Turnert also describes it, and gives a figure of the whole plant drawn from a specimen in the Herbarium of the Jardin des Plantes at Paris. The next record is that of Lamouroux, $\neq$ who, in 1813 , mentions this plant under the name Laminaria potatorum. The genus Sarcophycus was subsequently founded for its reception by Kützing. $\$ \mathrm{He}$, was, however, under a misapprehension as to the nature of the oogonia, since he regarded these as tetrasporangia, and, believing the plant to be one of the Floridce placed it in the order Chatangiea. Its systematic position was, however, clearly recognised by Hooker, for in his Flora Australica, p. 456, after describing Durvillea Harveyi, he mentions this plant under the name Laminaria potatomu, and observes that it probably belongs to the genus Durvillea. Lastly, Areschoug,\| in I 847, gives a description of the plant under its name of Sarcophycus potatorum.

The genus founded, as has been noted, as the result of a misapprehension. has been retained, for, although the genera Sarcophycus and Durvillaca are very closely allied, they differ in the fact that, while the frond of Sarcophycus is solid to the centre, that of Durvillae is, beneath the cortex, lacunar in structure, the lacunæ being separated by strands of anastomosing filaments. I am indebted to Mr. Bracebridge Wilson of Geelong, Australia, for collecting the material on which I have worked.

The mature plant of Sarcophycus potatorum consists of a disk, a stipe, and a frond portion. From the flat and more or less circular disk there rises a stipe, which is cylindrical below and flattened above. The stipe bears a huge segmented frond, the segments of which are of tough, leatherlike consistency, and reach an enormous length and considerable thickness.

A section through the frond shows that it is composed of a cortical

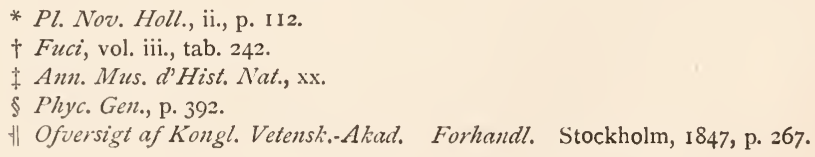


and of a medullary portion. The cortical portion is made up of parallel filaments running perpendicularly to the surface of the thallus. These filaments are very closely packed and regularly septate, causing the cortical portion to present the appearance of a compact mass of parallel rows of cells. As the filaments pass down to the medullary portion, they cease to run parallel to each other, and branch out irregularly in all directions, anastomosing more freely, while the individual cells expand in diameter, and the septa are further apart. Thus the medullary portion is made up of a mass of branching and anastomosing filaments running in every direction, forming a tissue which is looser than that of the cortical portion. The conceptacles extend to the same depth as the cortical portion, their bases being surrounded by filaments of the medullary portion. The material at my disposal consisting only of mature parts of the fronds, I have been unable to investigate either the mode of apical growth or the mode of development of the conceptacles.

The male conceptacles are of the ordinary Fucaceous type, and contain antheridia borne on branching filaments (plate XII., fig. I).

The female conceptacles (plate XII., fig. 2) contain oogonia, the contents of which divide into four oospheres in the following manner:-the protoplasm of the immature oogonium divides into three transversely, and the middle portion then divides again into two longitudinally. This mode of division was first observed by Kützing, who, as has been already noted, regarded the four resulting oospheres as tetraspores. A peculiarity about the oogonia is that, while many of them are developed in the usual manner from the lining cells of the wall of the conceptacle, others are borne laterally on branching filaments (plate xiI., fig. 3). These filamunts are longer, and their component cells are larger, than in the case of the antheridia-bearing filaments. There are only a very few sterile filaments on either the male or the female conceptacles, and these occur chiefly at the mouth of the ostiole.

Frances G. Whitting.

(For explanation of figures on plate xiI. see p. 46.) 



\section{VII.}

\section{ON CHLOROCYSTIS SARCOPHYCI.-A NEW}

\section{ENDOPHYTIC ALGA.}

When Mr. Bracebridge Wilson was collecting Sarcophycus, he observed the occurrence of raised circular patches, forming gall-like structures on certain of the fronds. He collected and sent to the British Museum, for the purpose of investigation, material on which such patches occurred, saying that he found them to be caused by what he took to be an unicellular Protococcaceous Alga. An examination of this material, which was put into my hands, has proved that this is indeed the case, and I will proceed to a description of these peculiar patches and the endophyte producing them.

The patches (plate XII., figs. 4, 5, 6) vary in size from a quarter of an inch to one inch in diameter, and are generally circular, but sometimes rather oval in form. They are accompanied by a bulging of the frond causing malformations, of which, while one surface is raised above, the other is somewhat depressed below the surrounding portion of the frond. The surface generally presents either a smooth or a corrugated, rough, and decomposed appearance, sometimes only one, and sometimes both surfaces being thus affected.

These malformations are caused by the growth of an unicellular endophytic Alga in greater or less abundance between the filaments of the cortical portion of the thallus.

The endophytic cells (plate XII., fig. I0) are thin-walled, chlorophyllaceous, various in size, and irregular in shape. They appear to vary in shape according to the pressure exerted upon them by the surrounding portions of the thallus. The cell when young contains homogeneous protoplasm (plate XII., fig. IOa), which at first, completely filling the cell-cavity, often shrinks away later from the cell-wall. Later, by the process of free-cell-formation, the protoplasmic contents become differentiated into a very large number of small spores, which 
gencrally completely fill the cell-cavity (plate XII., fig. II). I have found the number of spores in many cases to exceed one hundred, the number, however, varying according to the size of the cell containing them. Even in the spirit material on which I have worked there often remains a decided green colouration of the contents of a cell before sporeformation; on the other hand, there is always a marked diminution of colour after spore-formation has occurred. Besides these two prevailing conditions of the contents of an endophytic cell, there remains yet a third condition, the meaning of which I shall have to discuss later. In this the protoplasm is segmented into portions of considerably larger size than the small spores which I have described (plate XII., fig. IO). The segmentation appears to proceed simultaneously throughout the whole protoplasm, and the resulting segments, though fairly regular in size, are not very uniform in shape; the green colouration is as well marked as it is before such segmentation has occurred.

Of the endophytic and unicellular Algæ hitherto described, the species to which I believe this endophyte of Sarcophycus to be the most nearly allied is Chlorochytrium inclusum, described by Kjellman*, in the fronds of the Floridean Sarcophyllis arctica. The spore-containing cells which I have described, though considerably smaller in size, yet bear a most striking resemblance to those figured by Kjellman. Kjellman refers his species to the genus Chlorochytrizm, but it seems probable that it, together with other marine forms, should be placed in the genus Chlorocystis of Reinhard, and I venture to think that, so far as can be judged without knowing the whole life-history, the species occurring in Sarcophycus belongs to the same genus, and I have therefore named it Chlorocystis Sarcophyci.

The genus Chlorocystis was founded by Reinhard $\dagger$ on Chlorochytrium Cohnii, described by Dr. Wright $\ddagger$ as occurring in several species of Schizonema, in Polysiphonia urceolata and other marine Algx.

The chief point of distinction between the two genera is that in Chlorochytrium spore-formation occurs by repeated division of the protoplasm into two, the resulting portions being separated from each other by a cell-membrane, while in Chlorocystis the spores arise by free-cell-formation.

The characteristics of the genus Chlorocystis are given as follows in De Toni's Sylloge Algarum (vol. i., p. 637) :-'Cellulæ sphæricæ, tuberculo laterali (ut in Chlorochytrio) instructæ, chlorophora perforata varie

* Algce of the Arctic Sea, p. 320, tab. $3 \mathrm{I}$.

+ Proc. New Russian Society of Naturalists, vol. ix., p. 214.

† Trans. of Royal Irish Academy, vol. xxvi., p. 355. 
lacerata ... pyrenoide unico instructa. Propagatio zoogonidiis e plasmatis divisione simultanea ortis et sine copulatione e membrana cellulæ matricalis examinantibus.'

Chlorocystis Sarcophyci departs from the generic character in the absence of any cellulose protuberance or neck-like portion. This, however, would not appear to be a very important point, for Dr. Perceval IVright, to whom I am indebted for very kindly examining some of my slides, informs me that, when he has found Ch. Cohnii developed in the interior of a celltissue, the cells are sometimes quite globular. (See also Kjellman, loc. cit., figs. I0, I7.)

There is difficulty in explaining the division of the protoplasm into the larger segments I have described above. I thought at first that, in some cases at least, the protoplasm might become thus segmented before the final differentiation into spores. Since, however, I have never found any of the segments in question differentiated into small spores, which always arise, on the other hand, by differentiation of the original homogeneous protoplasm, this interpretation is not tenable. A somewhat similar segmentation of the protoplasm was observed by Cohn* in the cells of Chlorochytrium Lemne and was regarded by him as a stage in the formation of the spores. This observation was, however, not confirmed by Klebst, who found the spores to be formed by repeated division of the protoplasm into two.

Another possible interpretation of the segments is that they are larger spores, in which case this would present a parallel with the small and large spores of Chlorocystis Cohnii. Since, however, in the material I have examined I have found these segments, though fairly regular in size, to lack uniformity of shape and in many cases the definitely rounded-off appearance of the small spores, I should not be justified in offering this explanation with any degree of certainty. The nature of these segments must therefore be left open to be decided by the result of future investigation. An examination of fresh material would probably offer an immediate solution of the difficulty.

There remains only to be described the mode in which the endophytic cells produce the malformations, and the manner of their escape from the tissue.

The malformations exhibiting considerable variations in external appearance and minute structure, it will be convenient to describe them at three arbitrarily chosen stages.

There are, in the first place, those which, while presenting the usual bulging of the frond, have their surfaces smooth and not decomposed.

* Beiträge, bd. i., heft 2 . + Bot. Zeit., vol. xxxix. 
These, when cut across perpendicularly to the surface, show a very slight amount of swelling in the cortical tissue of one or both surfaces, the whole thickness of the tissue in the diseased portion being slightly greater than that of the surrounding portions of the frond. A section of the raised surface of such a malformation (plate XII., fig. 7) will show the endophytic cells between the somewhat swollen filaments of the cortex, thus diverting these from their perpendicular course. Although cells containing spores may occur, yet the contents are for the most part of homogeneous protoplasm.

Secondly, there are those of which one surface at least is rough and disintegrated, and when cut across show increased swelling in the cortical tissue, the whole thickness of the tissue being considerably greater than that of the surrounding portion of the frond. A section (plate XII., fig. 8) shows endophytic cells in the greater number of which spore-formation has taken place among the cortical filaments which are in this case swollen and becoming separated from each other. In parts the individual cells have become rounded off from each other, forming a loose tissue which at the surface is completely broken down into a discoloured mass of disorganized cells. It is by this decomposition of the filaments surrounding them that the endophytic cells are set free. As the decomposition proceeds, the endophytic cells in deeper portions of the cortex are enabled to escape; in some cases this escape is facilitated by the exfoliation of large portions of the diseased cortical tissue.

Thirdly, there are those which when cut across show that the thickness of the thallus is considerably less than in the surrounding portions of the frond, owing to the destruction of a portion of the cortical tissue. A section (plate XII., fig. 9) shows the loose tissue described above broken down at the surface into a disorganized mass without any remaining endophytic cells. These, in fact, have all escaped from the tissue.

It appears, then, that the cells of Chlorocystis Sarcophyci are able, in some manner (and perhaps especially during the process of spore-formation), to exert an influence upon the surrounding tissue, causing at first swelling and loosening of the tissue, and finally complete disintegration of the cells. In this point it differs from the species that have been hitherto described, for these inflict no injury on the plant in which they live. The three stages described above may, however, occur in one and the same malformation, for the disintegration proceeds centrifugally, and in many cases a gradation occurs from a peripheral portion, of which the cortex is almost uninjured, to a central portion, in which it is completely disintegrated.

The disintegration of the tissue may proceed still further, for $\mathrm{Mr}$. 
Bracebridge Wilson describes these malformations as resulting in the formation of circular holes. I had only one instance of a malformation with a central hole, but I think that in this case the destruction of tissue was certainly due to the action of the endophytic cells, for these were extremely abundant in the very thin tissue surrounding the hole. It is easy to suppose that, when once the denser cortical portions of both surfaces had disappeared, the looser medullary portion would soon be destroyed.

The endophyte may or may not occur among the filaments of the depressed surface of the malformation, and when it is present the injury to the tissue is not generally so far advanced as that of the raised surface.

The presence of the endophyte among the cortical filaments of both surfaces of the thick mature frond would seem to imply that the infection occurs when the frond is quite young and very thin. This perhaps would also explain the bulging of the frond in the diseased portions, for an infected surface becoming raised and swollen might, as it were, carry up with it the whole tissue of a thin and delicate thallus. This, however, is merely hypothesis for the mode of entry of the endophyte into the plant, and the first stages of its life-history within the tissue are entirely unknown to me. I have been unable to find any trace of the endophyte in any younger stage than those I have described, probably because I have had no young material to examine.

Briefly to sum up the results of this investigation, there exists among the cortical filaments of the frond of Sarcophycus potatorum an unicellular Protococcaceous Alga, which, so far as I am able to judge from the lifehistory known to me, belongs to the genus Chlorocystis, and I have named it as follows :-

Chlorocystis Sarcophyci n. sp., cellulis globosis oblongis vel irregularibus, Iо- $40 \mu$ diam., in statu vegetativo viridibus, in matrice omnino inclusis, collo destituto, zoogonidia emittentibus.

Hab. in Sarcophyci frondibus ad oras Novæ Hollandiæ prope Geelong. -coll. J. Bracebridge Wilson.

It differs from the species hitherto described, in that, while these inflict no injury on the tissue of the plant in which they live, $C$. Sarcophyci produces conspicuous malformations, and, in consequence of the disintegration which it in some way induces, its spores are enabled to escape from the tissue. A study of fresh material might determine whether the endophyte derives any nutritious benefit from the disintegration of the cells of which it is the cause; whether, in fact, this is a case not merely of 'Raumparasitismus,' but of true parasitism.

FRANCES G. WHitTING. 


\section{EXPLANATION OF PLATE XII.}

Fig. I. Sarophycus potatorum. Male conceptacle ( $\times$ I05).

Fig. 2. ",

Fig. 3.

Female conceptacle ( $\times$ 105).

Oogonia developed on branching filaments : $a, b, c$, being stages in the formation of oospheres $(\times 440)$.

Figs. 4, 5, 6. Chlorocystis Sarcoplyci. Malformations on frond of Sarcophycus potatorum. Nat. size.

Fig. 7 .

Section of malformations, first stage, showing endophytic cells ( $\times$ I05).

Fig. 8 .

Fig. 9.

Fig. so.

,

Fig. I I.

Section showing the endophytic cells escaping by the decomposition of the cortical filaments ( $\times$ 105).

Section of the disorganized tissue after the escape of the endophyte $\left(\times 10_{5}\right)$.

Group of endophytic cells : $a$, contents undivided ; $b$, larger segments ; $c$, spores $(\times 440)$.

Group of spore-containing cells $(\times 440)$. 


\section{VIII.}

\section{ON HALICYSTIS AND VALONIA.}

While dredging in the Clyde Sea area, last August, with Dr. Schmitz of Greifswald, we were so fortunate as to find, both on the bar at the entrance to Loch Goil and in the Kyles of Bute near Inchmarnock, an Alga of a generic type new to British seas. It was growing in 8-I I fathoms water, attached to sheils and to Lithothamnion. Our discovery was the Alga at present known as Halicystis ovalis, Aresch. (=Valonia ovalis, Ag. Spec. Alg., i. p. 43I, and Gastridium ovale, Lyngbye, Tent. Hydrophyt. Dan., p. 72, tab. I8b), and its nearest occurrence to our shores previously recorded was Molde, Norway (Areschoug), and the Faroe Islands (Lyngbye). Bornet has recorded it also from Biarritz (Alg. Schousb., p. 50).

H. ovalis has the appearance of a small round or oval bladder (plate XIII., fig. I), of the colour of a green grape, attached to its substratum by a very short, delicate, cylindrical stalk, terminating downwards in a minute disk. The cavity of this relatively thick-walled stalk communicates upwards directly with the interior of the bladder. There is no formation of rhizoids such as are found in Valonia.

Dr. Schmitz and I have both independently examined the minute structure of this plant, and our observations are in exact agreement. He has been good enough to send me in his own words an account of his examination, and I have translated it for convenience sake, as follows :The somewhat thick membrane of the unicellular bladder appears outwardly quite smooth, and shows none of the striation to be seen easily for the most part in Valonia cells. The stratification of this membrane is exceedingly fine and barely recognisable, and has no appearance of exfoliation (plate xiII., fig. 4). This membrane in the living plant is coated with a thin layer of protoplasm, in which very numerous small chlorophyll-grains and nuclei are embedded. The great lumen is filled 
with cell-sap. The small, green chromatophores (plate XIII., figs. 2 \& 3) lie almost everywhere in a single more or less dense layer in the protoplasmic coat. At the upper arched portion of the bladder this layer becomes very dense, and in places so much so, that the granules no longer lie flat, but become partly tilted over on each other. Below this the press of granules is less, and on the sides where they lie flat, spaces appear free from granules. The chlorophyll-grains themselves are small, flat roundish or oval disks of somewhat varying size and rounded outline, and I have never seen sharply angular or lobed forms. These disks are whoily without pyrenoids, and I could not discover in the minutely examined specimen of this Alga any amylum in the whole protoplasmic layer, rich in chromatophores as it is.

Very numerous minute nuclei are distributed among the chromatophores, or lie on the inner surface of the chromatophore layer. They are flattened disks, round or oval in outline, and contain each a minute nucleolus. The nuclei are to be detected only here and there in specimens hardened without staining; but after this process they may be easily recognised. Without staining, the minute glistening nucleoli may be recognised in the spaces free from chlorophyll-grains. The nuclei are scattered irregularly throughout the whole protoplasmic layer, now singly, now in pairs, or in groups of several near each other. In the living plant they probably wander in the protoplasmic layer, as for example those of Codium* do.'

Dr. Schmitz then proceeds to point out the characters which distinguish Halicystis from Valonia, to some species of which it bears, as will be seen later, a very striking resemblance. The nuclei of Valonia, as he has pointed out, $\uparrow$ are much more compact and more evenly distributed at fairly regular distances in the protoplasm. The chromatophores exhibit an irregularity of shape, being roundish, but angular, some of them with sharp angles, and of varying size; moreover, some of them are provided with pyrenoids, and these are of regular occurrence among the others, which have no pyrenoids. He comes to the conclusion that the above differences of characters in combination with the non-development of rhizoids and a cell-membrane so little stratified as to exhibit no exfoliation completely justify the separation of Halicystis from Valonia, as Areschoug has done. Dr. Schmitz goes further, and insists on the removal of the

* Berthold, Zur Kenntniss der Siphoneen und Bangiaceen (Mittheil. d. Zoolog. Station zu Neapel, ii., p. 76).

+ Beobachtungen über die vielkernigen Zellen der Siphonocladiaceen. Halle, I879.

$\ddagger$ Phyc. Scandinav., p. 446 . Upsala, I850. 
genus from the Siphonocladacea, to which Valonia undoubtedly belongs, to the Siphoneae, with which group it agrees in the characteristic chlorophyll layer, and the arrangement of its nuclei. Although I am most strongly inclined to agree with this determination of the position of Halicystis, I confess to a preference for the more cautious attitude of awaiting the story of its reproduction before committing myself to full agreement. I have observed all the details described above by Dr. Schmitz, working quite independently and simultaneously at the material we collected, but such histological details appear to me to be by themselves insufficient support for this step. Since I may fairly claim, however, to have given in several papers unqualified support to Dr. Schmitz's admirable work in establishing the group of Siphonocladacee, ${ }^{*}$ I may take this opportunity of expressing surprise at the small extent to which it has been adopted, and to my conviction that students who cling to the old system will, after due study, discover the Siphonocladacee to be one of the most natural orders of the green Algx. With regard to the present case I must be understood to express not dissent, but merely hesitation. If we grant the point, the question of its position among the Siphonea becomes interesting, and on this point Dr. Schmitz's remarks, which I translate, are of great value :-

'The genus Halicystis stands in a somewhat isolated position among the Siphoner, but its vegetative structure, which is all we know of it, recalls that of Botrydium. $\dagger$ This genus, apart from its occurrence in fresh water, is mainly distinguished from Halicystis by its branching filamentous rhizoids. In its simple bladder-like thallus Halicystis is further removed from such genera as Vaucheria, Derbesia and Bryopsis, which possess a more or less branched filamentous thallus. A more exact determination of its position among the Siphoneae can only be made when the whole life-history and reproduction of Halicys is has been ascertained.'

Since Reinke has recently ${ }_{+}^{+}$mentioned the discovery of $H$. ovalis in Heligoland, it may be mentioned that Dr. Schmitz found it there so long ago as September, I88I, while dredging in the Nordhafen, and he even then came to the conclusion that it belonged to the Siphonee rather than the Siphonocladacce. During the winter of I879-80, Dr. Berthold called his attention to another form obtained also by dredging in the Gulf of Naples on stony ground, rich in corallines. On comparing the preparations

* Sitzber d. Naturf. Gesellsch. zu Halle, Nov. 30, 1878.

$\dagger$ Botrydium possesses in the upper portion of its bladder-shaped thallus numerous small disk-shaped chromatophores, free from pyrenoids, as Halicystis does. The assertion of Wille (Engler \& Prantl. Pflanzenfamilien, i., p. 123), that in the Botrydiaceae only a single much-lobed chromatophore is present, is not correct for Botrydium; Codiolum, which Wille (loc. cit.) places in the Botrydiacea, does not belong to the Siphonece at all; the unicellular thallus of $C$. gregarium possesses a single much-lobed chromatophore with numerous pyrenoids and a single nucleus.

$\ddagger$ Berichte der deutschen botan. Gesellsch. 1889, p. 369 . 
he then made of this form with $\mathrm{H}$. ovalis, he has come to the conclusion that the Neapolitan plant is another species apparently identical with the form described by Zanardini* in the Adriatic as Valonia ovalis. This form, though smaller, much resembles $H$. ovalis externally, but differs in having a shorter and more blunt stalk, a more uneven outer surface, but mainly in having larger chromatophores of different shape (plate xIII., fig. 5). These occur in great numbers, and are of a rather long spindle shape, and are provided in the centre with a single clear pyrenoid, very like the chromatophores of Bryopsis. Its nuclei, however, resemble generally those of $H$. ovalis. Dr. Schmitz proposes to retain this form under Halicystis, under the name of $H$.paroula, and calls attention to the fact that similar differences in the chromatophores of different species in the same genus are to be found in Derbesia and Vaucheria. I may be excused for pointing to such a circumstance in justification of my caution in attaching what may be undue weight to evidence based on these characters.

The collection and examination of Halicystis ovalis recalled to me certain observations I made in 1886 in Grenada on Valonia ventricosa, of which I then obtained magnificent specimens. This remarkable plant, consisting of a cell as large as a hen's egg, and of much the same shape, varying to the shape of a pear (plate xIII., fig. 6a) I found growing in fairly shallow water (I to 2 fathoms) attached to Galaxaura lapidescens, and in 5 fathoms water on the rhizoids of Avrainvillea longicaulis (plate XIII., fig. $6 \mathrm{~b}$ ), the latter being much smaller specimens. It resembles Halicystis in consisting of a single great, unbranched cell, and differs from other species of Valonia (except $V$. Forbesii probably) in this respect. It possesses no stalk like Halicystis, but agrees with Valonia in the production of rhizoids terminating in tenacula (plate xilI., fig. 7). Its cell-wall is stratified and exfoliates readily (plate xilI., fig. Io) on cutting it in section, and exhibits faint striation. The chromatophores possess a pyrenoid (plate XIII., fig. 9). In its protoplasmic layer there are both single starch-grains and masses of amylum, as in other species of Valonia. In these respects it shows distinct differences from Halicystis.

The remarkable point, however, in these specimens (as also in others collected in Bermuda by Mrs. Whelpdale) is the occurrence in them of reproductive organs. Since such organs have been hitherto unknown in Valonia (the so-called 'germ-cells,' figured by Nägcli, Kützing, and others, being concerned in branching, but possibly also in reproduction) their occurrence deserves detailed description. The cells in question (plate XIII., fig. $8 a, b, c, d$ ) have plainly arisen by free cell-formation within 
the great mother-cell, and in this process I have discovered various stages in different specimens. It evidently proceeds slowly, and is not a simultaneous act, since in some specimens comparatively few cells are to be found, while a considerable amount of free protoplasm remains, and in others the cells are very numerous, while mere traces of free protoplasm are left over. They are, moreover, of various sizes, and, while generally round, odd forms are to be met with (plate XIII., fig. $8, b, c, d$ ), dumb-bell shaped in varying degree, and others suggesting a process of sprouting in yeast fashion. Their membranes vary slightly in thickness. They occur, not only within the great mother-cell cavity, but even in the rhizoids and the small marginal cells from which these spring.

I observed these bodies not only alive in Grenada, but have frequently studied them since in the preserved material. Dr. Schmitz, to whom I sent specimens in spirit, has been good enough to confirm my observations in every detail, and to suggest that possibly they are abnormal reproductive bodies produced by slight accident to the plant in being gathered, as he has observed a similar case in Siphonocladus IVilbergi (V zelkernige Zellen der Siphonoclad., p. 33), or it may be by too strong illumination, as in the formation of aplanospores in Botrydium. My own view of the matter is simply that they are the normal reproductive organs of Valonia (a possibility not excluded by any means by Dr. Schmitz also) for the reason that I could find no support for the view that they are abnormal. Not only do they occur in all the specimens I have examined, both from Grenada (several localities) and from Bermuda, but I have seen them in the condition described shortly after their removal from the water, before accident, if it had occurred, could well have had time to operate in this fashion. That they are not the result of strong illumination is plain from the fact that they occur in specimens buried among the rhizoids of Avrainvillea in coral-sand under five fathoms water. On the other hand, their irregularity in size and shape favours the view of their abnormality, but their variation in size may be accounted for by their gradual formation, as mentioned above, and the exceptional forms in point of shape may be explained by the slight abnormality of unequal division of the protoplasm in the process of their formation.

Attempts to cultivate them were unsuccessful under the circumstances of my position in Grenada, though in one instance I observed the same cells unchanged for several successive days. As the plant is not a rare one in the West Indies, and its condition as described frequent, further inquiry into the development of these reproductive bodies ought not to present serious difficulty.

George Murray. 


\section{EXPLANATION OF PLATE XIII.}

Fig. I. Halicystis ovalis. Natural size.

Fig. 2. " " Chromatophores and nuclei. Drawn by Ir. Schmitz.

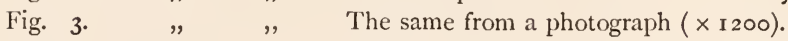

Fig. 4. " $\quad " \quad$ Section of membrane with layer of contents $\left(x_{150}\right)$.

Fig. 5. Halicystis parvula. Chromatophores and nuclei. Drawn by Dr. Schmitz.

Fig. 6. $a$ and $b$, Valonia ventricasa. Natural size.

Fig. 7 .

Fig. 8. $a, b, c, d$. ,

Fig. 9 .

Rhizoids ( $\times 66$ ).

Fig. Iо.

,

,

,
Reproductive bodies $(\times 375)$.

Chromatophores $(\times 750)$.

Section of wall, showing exfoliation ( $x_{15}$ ). 
Phyc. Mem. Part II.

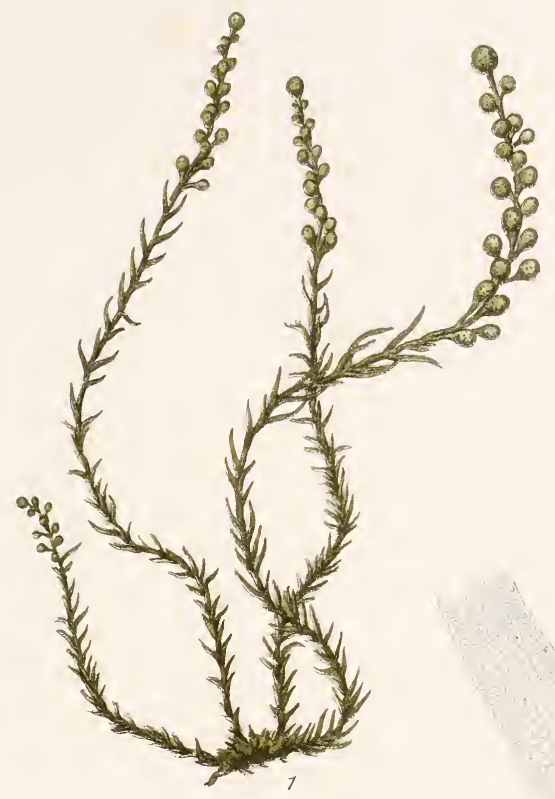

2

3

Berjeau \& Highley lith.

A. $L$ is de.

COCCOPHORA I.ANGDBQPF II R:? 



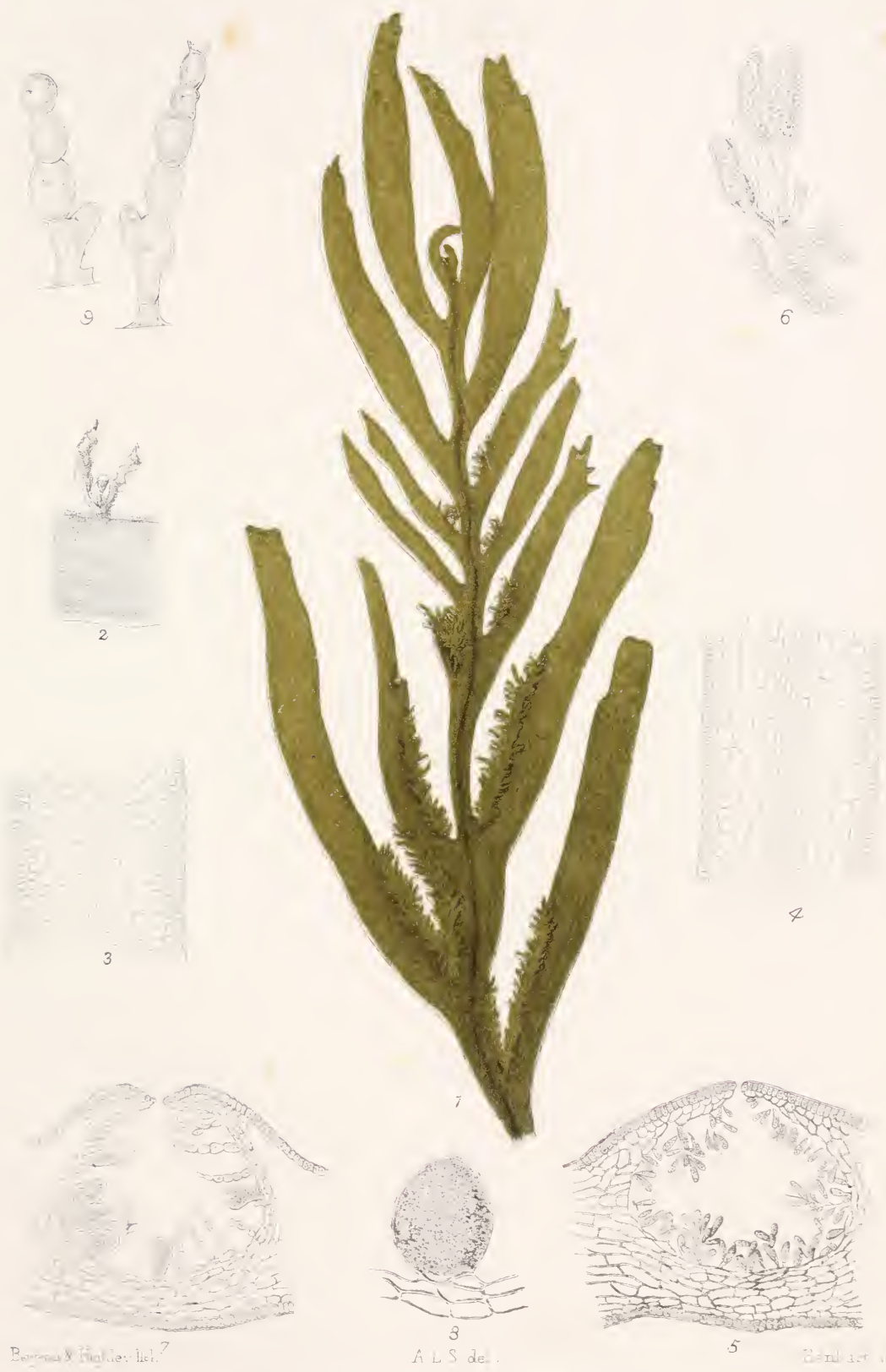





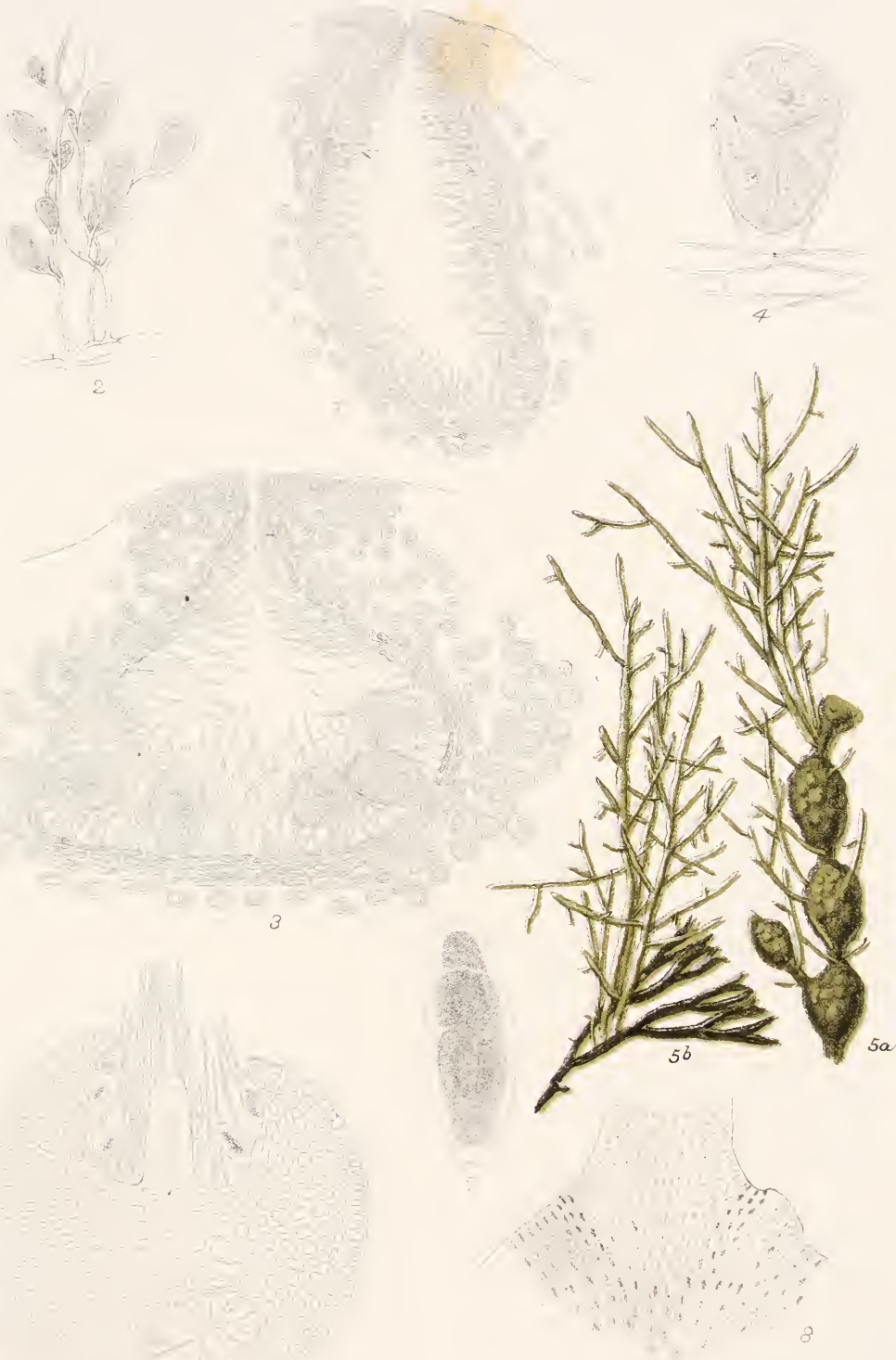




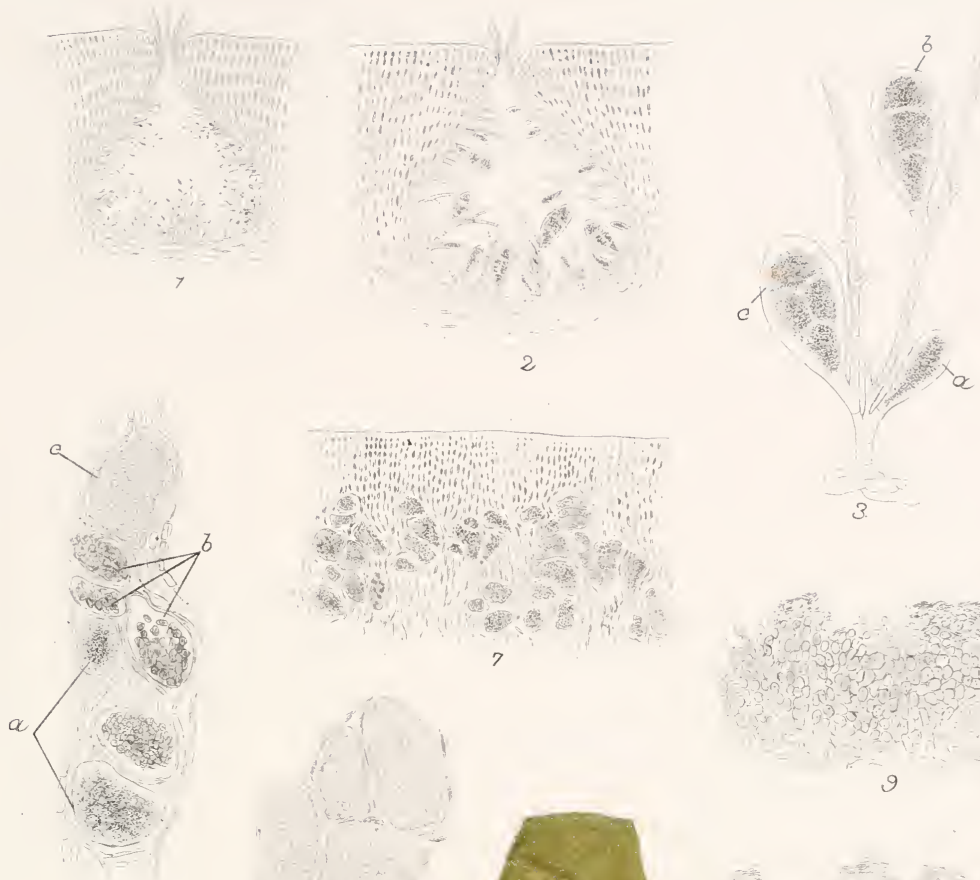

70
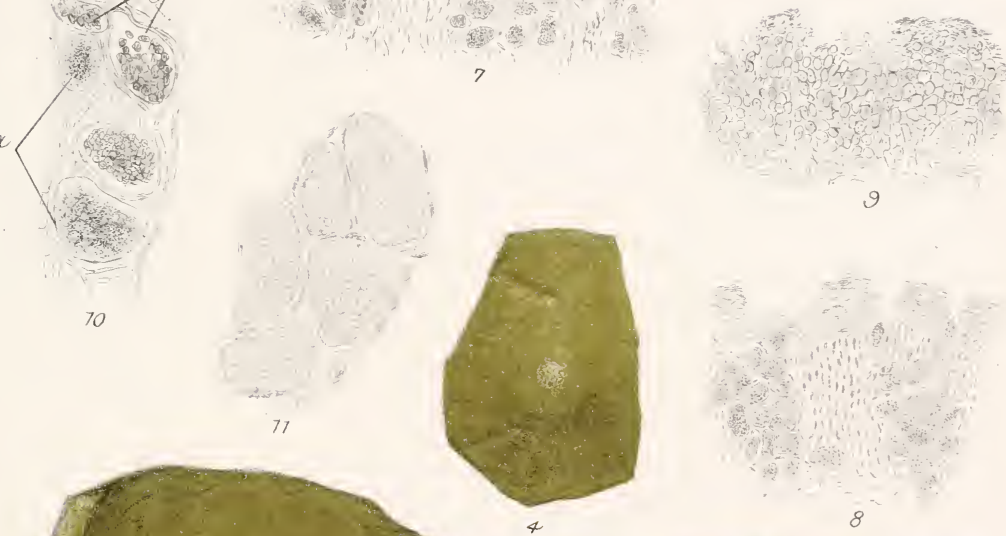

9
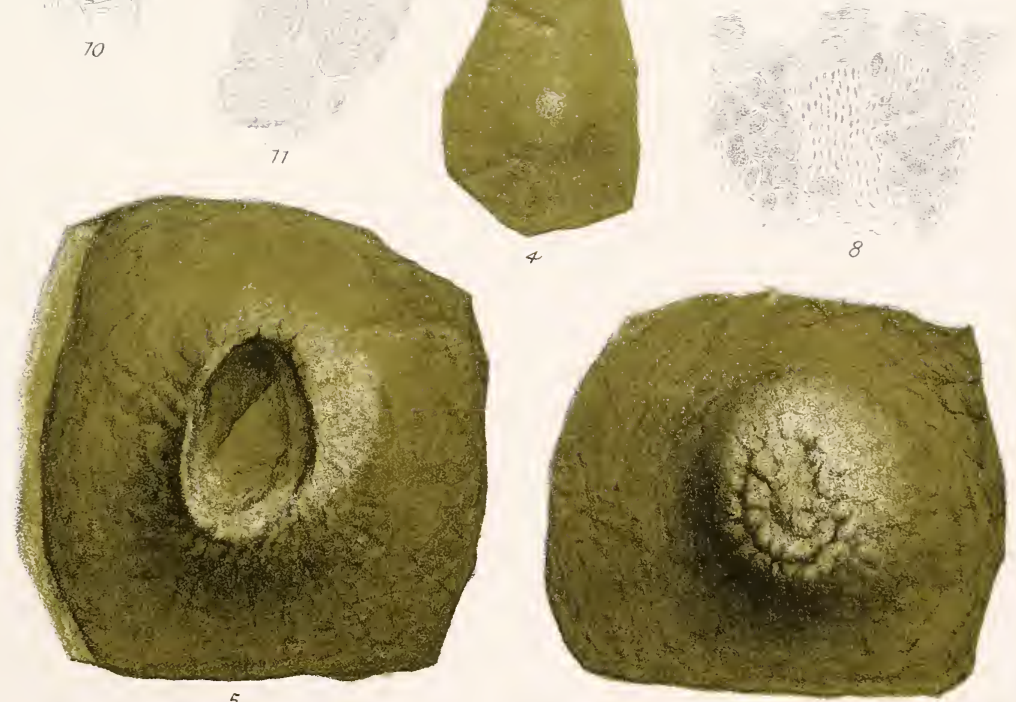

5

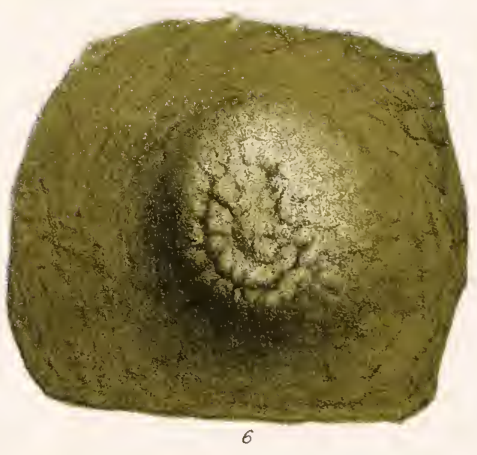

F.G.W. del

Hanhart 2mp

Berjeau \& Highley lith.

SARCOPHYCUS POTATORUM Kütz.(1-3) CHLOROCYSTIS SARCOPHYCI Whrt. (4-: 


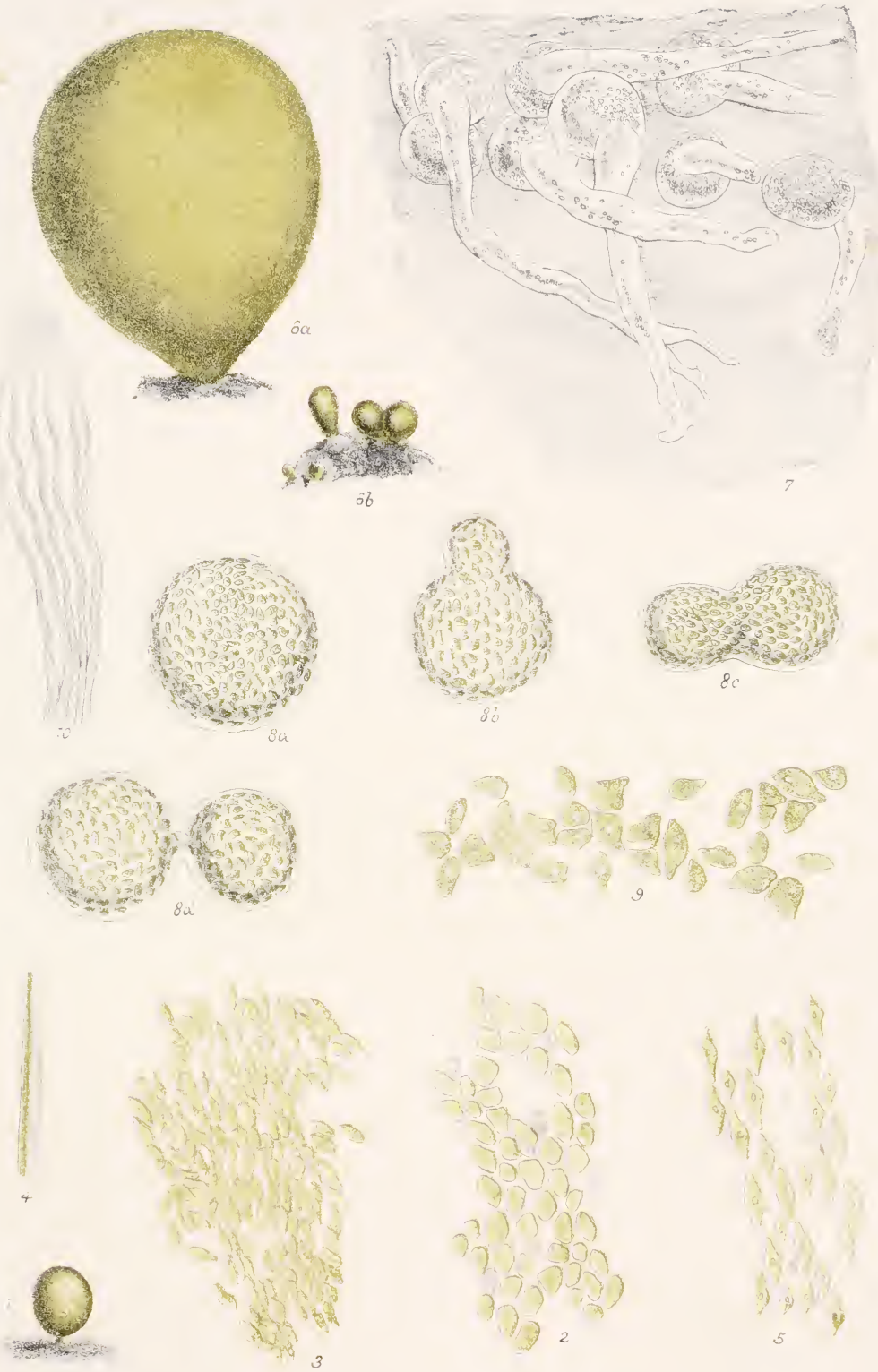



\section{IX.}

\section{ON THE STRUCTURE OF HYDROCLATHRUS BORY.}

HYDROCLATHRUS SINUOSUS Zanard. and H. cancellatus Bory have by recent authors been separated from the group of the Asperococcoidea in which they were formerly placed, partly on account of the structure of their thallus, and partly because they have not yet been shown to possess any other than plurilocular sporangia, while all those plants now placed in the group of the Aspcrococcoidea have, with one exception,* welldefined unilocular sporangia only.

I examined the plants because I have been unable to find any detailed description of them, and also with a view to determining the method of development of certain groups of hairs scattered abundantly over the surface. These are, apparently, analogous to the so-called 'fasergrübchen' $\dagger$ or 'cryptostomata' of the higher Fucacee, and it seemed possible that the development of such simple forms might throw light on the origin of structures which occur so generally throughout this group.

The plants examined were collected at Anguilla by Mr. W. R. Elliott, and in the Gulf of Manaar by Mr. Thurston; I have only, therefore, been able to describe specimens preserved in alcohol.

* J. H. Buffham, Journal of Botany. I 891

+ Throughout this and the succeeding paper, 'cryptostomata' will be used in place of 'fasergrubchen.' Though there are objections to the term, these do not outweigh the advantage of using an adopted term of classical derivation in place of a German word. (ED.) 
The form of Hydroclathrus sinuosus is that of a hollow sphere, with a slightly corrugated surface, the largest specimens examined having a diameter varying from two and a half to three inches. The plant adheres to stones and to other Algæ, but has no special organ of attachment. At first it probably consists of a solid mass of cells, but this condition is only transitory, since the youngest plants examined have always been found to be hollow, while the cells of the layer which borders the hollow interior generally present a ragged appearance, as if they had been torn apart from each other.

A section of the thallus (plate XIV., fig. 2) shows that it is made up of from five to six layers of cells ; those forming the outermost or epidermal layer are small closely packed polygonal cells, each with a well-developed nucleus and dense protoplasmic contents. Below them come one or two layers of cells larger than those of the epidermis and with thinner walls. The innermost cells of all resemble those above them, excepting that they show a marked increase in size, and take on a more spherical form owing to the absence of pressure. When they have reached their limit of growth the walls become torn, either on account of the constant tension exerted by the growing thallus or by degeneration of the substance of their cellwalls.

The peripheral walls of the epidermal cells increase slightly in thickness, thus forming a kind of cuticle which covers the whole plant, and is ultimately pushed off as a result of the outward growth of the epidermal cells below it during the formation of sporangia (plate XIV., fig. 3).

$H$. simuosus has neither an apical cell nor any area of special growth, and increase in size takes place by division of the epidermal cells.

While the plant is still quite young, there is no indication of the formation either of cryptostomata or sporangia, and the epidermal layer has everywhere an uniform appearance; but, as the thallus increases, a surface view of the epidermis (plate XV., fig. I) shows that localised changes are taking place simultaneously; an isolated cell or several cells in a group become separated off from the surrounding epidermis, each loses its polygonal shape and becomes cylindrical. This change in appearance denotes the first stage in the formation of a cryptostoma. In a radial section of such a group each cell is seen to be divided by a transverse wall, but there is no indication of such longitudinal division as occurs in neighbouring epidermal cells. The lower of the two cells again divides transversely, and this method of division continues till a long row of cells has been formed, making in fact a hair. Simultaneously with the formation of these hairs, the cells immediately surrounding them undergo similar changes, and thus the cryptostoma enlarges radially. Meanwhile 
the thallus continues its growth, so that the basal cells of the hairs which were originally in the same plane as the epidermis have now come to lie below it, and the whole structure is suggestive of a conceptacle.

$H$. simuosus is reproduced by spores contained in plurilocular sporangia. So soon as a cryptostoma is fully formed the epidermal cells immediately surrounding it begin to elongate, pushing up the overlying cuticle, which is finally ruptured (plate XIV., fig. 3), and peels off as the growth of the cells spreads centrifugally. From the appearance of many sporangia at different stages of development it may be seen that each epidermal cell becomes divided, as in the case of the hairs, by a transverse wall; the lower of the two cells, which represents the basal cell, remains unchanged, while the upper one divides transversely. Of the two cells thus formed the lower one divides longitudinally into two, the protoplasm of each half going to form a spore, while the upper half again divides transversely, and the same process of division takes place, with the formation of two more spores. Growth continues until from twelve to sixteen spores have been produced (plate XIV., fig. 4). Of the sporangia forming a sorus, those immediately surrounding the cryptostoma come to maturity first, and the spores are liberated; what becomes of them afterwards it is impossible to determine unless growing plants can be examined. After the liberation of the spores the sporangial walls gradually disappear, and the basal cells originate a new growth. They again elongate, and each is divided into two parts by a transverse wall; the lower half remains unchanged, and the upper one grows into a long, club-shaped paraphysis (plate XIV., fig. 5), the contents of which, in spirit material, are entirely concealed by a dark-brown colouring substance. In a young paraphysis this is distributed evenly all over the cell; in older ones it appears to be collected into small globules, but how much of this appearance is due to the method of preservation it is impossible to say. While the basal cells nearest the cryptostomata are giving rise to paraphyses, those farthest away are still producing sporangia, and, as the growth of the sporangia spreads radially from the cryptostomata, so also does that of the paraphyses, until finally all the sporangia have disappeared, and there are scattered over the thallus in the place of the sori groups of dark-coloured paraphyses, each having a central cryptostoma. The hairs of the latter are shrunken, and the cells have lost their contents, but they, together with the paraphyses, appear to persist throughout the remaining life of the plant. It is of interest to note here slight differences in the structure and appearance of the plants coming from different localities (cp. plate XIV., figs. 3 and 6). Thus the form of the inner cells of the thallus is round in the plants coming from Madras, and more elongated in those from Anguilla. Again, in the plants coming from Anguilla the crypto- 
stomata and paraphyses are sunk in slight depressions, whereas in the plants collected at Madras the surface is uniformly even.

Hydroclathrus cancellatus.- $H$. cancellatus, in outward appearance, offers an entire contrast to $H$. simuosus; the thallus consists of branches which anastomose to form a network with large or small intervening meshes. The whole plant is usually more or less spherical or ovate, and it is found sometimes growing together with and adhering to $H$. simusus or by itself, and attached to some other Alga.

While one region of the thallus is fully formed and capable of producing sporangia, another may be still in a state of growth. Some of the branches are flattened, others are almost cylindrical. Along the inner side of the latter, i.e., the side which is towards the interior of the whole net, the continuity of the epidermal layer is destroyed, and the underlying tissue appears to be ruptured almost as far as the central line of the branch (plate XV., fig. 3); the epidermal layers on either side of the line of division bend towards each other, and a section of such a branch is reniform rather than cylindrical. On all the branches cryptostomata and sporangia are present in various stages of development. Their growth, as far as I have been able to observe it, follows closely that of H. simusus, the material to which I had access being too young to show whether vegetative growth takes place from the basal cell of the sporangia, giving rise to paraphyses.

The point of interest about these plants is the very elementary method of development of the cryptostomata; and although no true conceptacle is formed with special lining cells, such as occurs in the higher Fucacea, yet the growth, both of the hairs and reproductive organs is initiated by the alteration in form and by the division of one of the epidermal cells, which might with truth be called an 'initial cell.'*

To leave this statement without a qualification would not, however, be exact, since my observations do not exclude the possibility of the initiative being taken by a small group of initial cells dividing simultaneously, instead of a single one. Whether the decision of this point may ultimately prove to have a bearing on the affinities of such organs with the cryptostomata of the Fucacea is one that at present I am unable to determine.

Margaret O. Mitchell. 


\section{EXPLANATION OF PLATES.}

Plate XIV.

Fig. I. Hydroclathrus sinuosus. Nat. size.

Fig. 2. ",

Fig. 3. "

Fig. 4. ,

Fig. 5 .

Fig. 6.
,

Section of thallus with young cryptostoma $(\times 250)$

a. Epidermal layer.

$b$ Inner cells of thallus.

c. Young cryptostoma.

" $\quad$ Mature cryptostoma with young sporangia $(\times 250)$

" Part of sorus to show adult plurilocular sporangia $(\times 250)$.

, Section of part of sorus, paraphyses having taken the place of sporangia $(\times 250)$.

Section of thallus of specimen from Anguilla, cryptostoma and paraphyses sunk in a slight depression $(\times 250)$.

\section{Plate XV.}

Fig. r. H. sinuosus. Surface view of epidermis of young plant to show first appearance of cryptostoma $(\times 250)$.

Fig. 2. Hydroclathrus cancellatus. Natural size.

Fig. 3.

Fig. 4 .

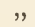

,
Section of thallus $\left(\times 25^{\circ}\right)$.

Cryptostoma $(\times 250)$. 



\section{$\mathrm{X}$.}

\section{ON THE CRYPTOSTOMATA OF ADENO- CYSTIS, ALARIA AND SACCORHIZA.}

THE bodies called 'fasergrübchen,' 'cryptostomata,' 'cryptes pilifères,' 'sterile,' 'neutral,' and 'vegetative conceptacles' which occur somewhat capriciously among the Phaophycea have been the subject of so much speculation that any new attempt to explain their nature and significance must be made on fresh evidence to have any claim on attention. While submitting such evidence, I do not now propose to set forth any conclusive argument, but to arrange old and new facts in such a fashion as to suggest a way out of the difficulties.

The development of cryptostomata in the Fucacea has been lucidly described, first, by Prof. Bower* in his paper on the development of the conceptacle in Fucacee. Valiante $†$ and Oltmanns $\ddagger$ have both extended his observations; and I find in a paper by Miss Barton $\S$ on Turbinaria an additional contribution to the subject. Prof. Bower regards them as incomplete sexual conceptacles, a view which has the advantage of definiteness, and one it would be hard to controvert; Oltmanns thinks that the fertile conceptacles are cryptostomata which have in time come to bear organs of reproduction; while Miss Barton puts

\footnotetext{
* Quart. Journ. Micr. Sci., xx.

$\dagger$ Fauna und Flora des Golfes v. Neapel. Leipzig, $188_{3}$.

$\ddagger$ Bibliotheca Botanica, heft 14 .

\$ Trans. Linn. Soc., vol. iii., part 5.
} 
forward a third view, which is just as likely to be true as the others, and certainly is very ingenious. She says: 'My own view of the matter is that the two forms of conceptacle are of equal antiquity, and were a later development in the ancestors of the Fucacee than the reproductive organs; therefore I consider neither form a development of the other, and the fact that one conceptacle contains reproductive organs, the other nothing but paraphyses, is an interesting point, but does not bear on the phylogenetic history of the conceptacles themselves.' I know so little about the ancestors of the Fucacee, that I must be content with a respectful attitude towards this statement.

As Prof. Bower has pointed out, the development of both conceptacles and cryptostomata is the same. To quote his words, it 'is preceded by the decay of one or more cells which occupy a central position with regard to the changes which follow. .... The cell or cells which decay are in all cases members of a linear series.' These words appear to me to be the true guide of those who investigate the development of such bodies.

When one comes, however, to compare the process as it takes place in Splacluidium - the process of making a conceptacular body for the development, not of oogonia and antheridia, but of zoosporangia-we find a slight but noteworthy modification. The process is so nearly allied, and the result achieved so similar, as to furnish material for direct comparison. Prof. Bower (loc. cit., p. 47) acknowledges the impossibility of finding a parallel instance while speaking of the destruction of initial cells. There is in Splachuidium not a parallel instance, but a closely comparable one. The peculiarly modified initial cell of Splacluidium is homologous with the initial cell of the Fucacea-but it persists. 'The epidermal cells' (page 5, ante) "lying around it undergo division, and the neighbouring cortical cells increase in size. These causes combine to place the initial cell in a depression (plate II., fig. 7). Hairs arise from the youngest epidermal cells, while others which were formed earlier surround the mouth.' In Fucus, it will be remembered that hairs are not produced until the formation of a young conceptacle with an ostiole, while the initial cell has decayed. The hairs in the conceptacle of Splachnidium are long, septate, and unbranched, increasing in length by successive divisions at the base, and giving the young conceptacle the appearance of the cryptostomata of the Fucacee. The sporangia are developed later. We have in fact in this type a sorus of sporangia and paraphyses comparable with those of Laminaria, rolled up and definitely limited in a conceptacular body, produced, not exactly in the same manner as the Fucaceous conceptacle, but after another manner directly comparable with it. 
The study of the structure and development of bodies of this character among the Phaophycea is, therefore, one of interest, so far as such may throw light on the origin of conceptacles. In connexion with the above comparison of the Laminarian with the Splachnidian sorus, it will be remembered with interest that cryptostomata occur in the Laminariaceae. Through the kindness of Mr. George Brebner, whom I asked to look out for them at Cumbrae, I have been so fortunate as to obtain good examples of their occurrence in Saccorhiza bulbosa and Alaria esculenta. Alaria has been frequently described as possessing cryptostomata. Greville* definitely refers to them as 'minute pores from which issue minute tufts of filaments' and Prof. Bower (loc. cit., p. 36) refers to them also in passing. I have not placed myself in antagonism to these authorities on this minute point, without arming myself with certainty. On plate XVI., figs. 4, 5, and 6, there will be seen a surface view of the Alaria cryptostomata, a transverse section of the frond showing them in a very early stage, and another in an advanced stage. It will be seen that so far no pits or conceptacles are formed, and in a very old Alaria frond which I have examined there was at most a depression one cell deep. The Alaria cryptostomata, if I may call them so, are tufts of hairs with basal growth, the cell at the apex of the hair being first cut off from the epidermal layer.

On plate XVI., fig. 7, I have illustrated the mature cryptostoma of Saccorhiza bulbosa. So far as I am aware, the mature stage of these bodies in Saccorhiza has not been figured before, and the reader who compares this figure with that of the young conceptacle of Splachnidium (plate III., fig. 3), while it yet bears hairs only, cannot fail to be struck by the resemblance in all respects except the persistent initial cell of Splachnidium. We have here, then, a body which has every claim to rank as a cryptostoma.

Mr. Setchell,* in his admirable paper on the life-history of Saccorhiza dermatodea has figured (loc. cit., plate II., fig. 22) an early stage in the development of the cryptostomata of $S$. dermatodea, which bears the most close resemblance possible to this early stage of Alaria. He says (p. 202): 'The first indication that a cryptostoma is forming is the appearance of a shallow, saucer-shaped depression. This will be seen to be due to the fact that the cells of the limiting layer in the region of this depression cease to divide as actively in a tangential direction as they have been doing, or as actively as their neighbours are doing. Furthermore, the cells of the outer cortex immediately below this point do not increase in size either so rapidly or to so great an extent as their neighbours do,' \&c. This is so like what happens in Splachnidium (without the persistent initial cell) as to be

$$
\text { * Alg. Brit., p. } 25 . \quad+\text { Proc. Amer. Acad. of Arts and Scicnces, vol. xxvi. }
$$


specially noteworthy. His description of the old cryptostomata, of which he does not give a figure, as saucer or shallow bowl-shaped depressions, with a large number of hairs projecting from the bottom, and with a rim projecting in over the edge of the depression, is sufficiently like my figure of those of S. bulbosa (plate XVI., fig. 7).

It appears to me to be a very probable explanation of the arrested development of the cryptostomata in Alaria (if I may put it in that way) that the frond of Alaria remains thin and easily lacerated-so thin as to give no room for the development of pits on either side-and I am confirmed in this view by Mr. Setchell's observation (loc. cit.) that 'the cryptostomata are present on the one layered portion of the blade (of Saccorhiza dermatodea) as clusters of hairs upon the flat surface.'

Kjellman,* in his paper on the forms of Adenocystis, has figured the cryptostoma of $A$. Lessonii Hook. et Harv. Mr. R. M. Laingt has also figured this body, and mentions and illustrates 'oval sacs containing zoogonidia' in the cryptostoma of Adenocystis. These sacs do not appear to belong to the species of Streblonema, which commonly invests the cryptostomata of this plant, and their presence may or may not be accidental. This plant has so many points of structure in common with Splachnidium that an occurrence of such sporangia would possess a particular interest. On examining the original material of Adenocystis collected during the Antarctic voyage, and also some New Zealand specimens, kindly lent me by Mr. Harvey Gibson, I was not satisfied with the accuracy of either Kjellman's or Laing's figures, and have therefore given another rendering of this structure (plate XVI., fig. 2), from which it will be seen that it bears a resemblance, both to the cryptostoma of its ally, Saccorhiza, and to those of Hydroclathrus (plate xIV.), illustrated by Miss Mitchell. Though I have examined a very young plant, I was unable to secure sufficiently early stages to ascertain the development of the cryptostoma. The result, however, is sufficiently remarkable. These cryptostomata occur in the middle of sori of unilocular sporangia, and the paraphyses and sporangia will be seen in the figure (plate XVI., fig. 2) on the very border of the depression. The sporangia and paraphyses are truly Laminarian, as would be expected. In the other Laminarice examined, the sorus occurs separately from the cryptostomata, but, in this form, in the middle of the sporangia and paraphyses, as if in a nascent effort (or a dying one, as the case may be), to form a conceptacle like that of Splachnidium. It will be remembered that a young conceptacle of Splachnidium bears hairs only at first and sporangia later on.

- Bihangtill K. Svenska Vet. Akad. Handlingar, bd. xv., afd. iii., No. I.

† Trans. New Zealand Institute, vol. xviii., p. 306, plate X., fig 2. 
In Hydroclathrus (plate XIV.) the cryptostomata occur also among the sporangia, which, in its case, are, of course, plurilocular.

In speaking of the conceptacular hairs of the Fucacea, Prof. Bower (loc. cit., p. 47, foot-note), in quoting Reinke on the 'sprossfaden' of the Dictyotacea, which are the precursors of the reproductive cells (conf. Splachnidium), makes what $I$ venture to think a prophetic remark of great weight, 'How far these may be compared with the initial cell or hair of the Fucacee it remains for closer observation to decide.' I anticipate with a measure of confidence, so far justified by facts, that this remark will eventually be borne out in many ways not then foreseen, otherwise than dimly, by its author.

It has been pointed out (conf. Falkenberg in Schenk's Handbuch der Botanik, vol. ii., p. 227), that in Scytosiphon single epidermal cells within a sorus remain sterile and grow out in the form of club-shaped unicellular paraphyses; and in Asperococcus and other allied forms, similar cells grow out in the form of long, branching filaments, of which the upper cells are very long, while the basal ones remain short, and probably act as the growing point of the hair. These hairs resemble those in the conceptacles and cryptostomata of the Fucacee, Splachnidium, Saccorhiza and Adenocystis, and those in the sorus of Cutleriacee and Dictyotacee. Interest is certainly quickened when we add to these cases that of Hydroclathrus, with its cryptostomata situated among the sporangia.

A comparison of the Fucaceous conceptacle and cryptostoma, the Splachnidian conceptacle with its persistent initial cell and the formation of its hairs yielding place to sporangia, the development of the Adenocystis cryptostoma in the heart of its sorus, the other Laminarian cryptostomata (Saccorhiza and Alaria) apart from the sorus, the cryptostoma of Hydroclathrus among its plurilocular sporangia, and finally the cases of the hairs in Asperococcus and the Cutleriacee and Dictyotacee-a comparison of these cases, and of the evidence plainly furnished by them, points very significantly to a possible origin of cryptostomata. I anticipate, from further research into the development of these bodies, evidence that may enable us to dispense with 'the ancestors of the Fucacee,' of which, however, I would speak with respect. I am aware that the hairs of the cryptostomata are regarded by many as adapted to absorptive and other nutritive functions. This may or may not be ; there is no proof of the matter, and probably more reasons to be cited against than in favour of such an opinion-but their function has nothing directly to do with the points in question, which are purely morphological. Moreover, in seeking for a solution of the difficulties surrounding the origin of these bodies, I do not intend to make the mistake of looking at cryptostomata only. 


\section{EXPLANATION OF PLATE XVI.}

Fig. I. Adenocystis Lessonii. Nat. size.

Fig. 2. ", $"$ Cryptostoma $(\times 375)$.

Fig. 3. Alaria esculenta. Young state, bearing so-called cryptostomata. Nat. size.

Fig. 4. " " $\quad$ Surface view of so-called cryptostomata ( $\times \mathrm{I}_{5} \mathrm{O}$ ).

Fig. 5. " " $\quad$ Transverse section of frond, showing very early stage of same $(\times 375)$.

Fig. 6. " " $\quad$ Advanced stage of same $(\times 375)$.

Fig. 7. Saccorhiza bulbosa. Mature cryptostoma $(\times 375)$. 
A COMPARISON OF THE MARINE FLORAS OF THE WARM ATLANTIC, INDIAN OCEAN, AND THE CAPE OF GOOD HOPE.*

IN delimiting the above regions I have been guided by what may fairly be taken to be their natural boundaries. The warm Atlantic is the tropical Atlantic, with a slight northward extension, to include Florida, the Bahamas, and Bermuda in the track of the Gulf Stream, and also Madeira and the Canary Islands, washed by that branch of the same stream which trends off backward to the south, the north equatorial current. I have not included the Azores, since they are not sufficiently under this influence, and their marine flora, so far as we know it, appears to be more akin to that of the north temperate Atlantic. On its southern boundary on the African coast the Cape region is permitted to come slightly within the tropics, so far as Walfisch Bay, on account of this coast being swept by a cold current from the south, bringing with it up to this point at all events such temperate forms as Laminaria, recently recorded from that place. The Indian Ocean similarly is the tropical Indian Ocean, but including the whole of the Red Sea, and extending to the south slightly outside the tropics down the coast of Africa, and including the whole of Madagascar. I am justified in this by the course of the warm Mozambique current. I do not include on the east Sumatra, which appears to belong to another

* A paper on this subject was read by me at the British Association at Edinburgh, 1892, and a table appears in the Report. The Cape totals in that table were much smaller, since the present table embodies the results obtained since then by Miss Barton, alluded to in this paper. 
region, though I have included a few forms from the Andaman Islands and Mergui. The Cape of Good Hope region has already been indirectly described, and, as has been said, extends for the reasons given slightly into the tropics on the west coast, and recedes slightly from that boundary on the east coast.

The accompanying table speaks for itself so far as the results of the comparison go, but a few remarks on what I take to be the meaning of the figures may be thought not too venturesome. If we look first at the last line of the table where the aggregates are set forth, it will be seen that the warm Atlantic has the largest recorded flora, viz., 859 species in 162 genera. I may explain that, out of this total, no less than 788 species in I 50 genera occur in the West India region, and that the rest of the warm Atlantic furnishes only $7 \mathrm{I}$ species in 12 genera not occurring in the West Indies out of a much smaller total flora. Allowing for the undoubted fact that a large number of West Indian species are bad species, there still remains a large balance in its favour. It has been better examined than any other part of the warm Atlantic, but still we may attribute this preponderance mostly to the favourable natural conditions, principally the coral formation of large portions of its island shores. On the coast of Africa there is not only no coral, but league after league of muddy shore, making a marine desert so far as Algæ are concerned. The Indian Ocean comes next, with $5 \mathbf{I} 4$ species in $\mathbf{I} 39$ genera. It possesses an enormous coast line, to a considerable extent favourable to the growth of Algæ (though including long desert stretches); but the bulk of the records are from Ceylon, Mauritius, and the Red Sea, while a very large proportion of the region is unexamined. As in "the West Indies, there is also here a considerable proportion of bad species, principally Sargassa, from the Red Sea. From the Cape we have 429 species in I4I genera. This remarkable total, from so short a coast line, is obtained from Miss Barton's list in the Journal of Botany, I 893. The flora previously recorded in books amounted only to 242 species in 99 genera, and this addition to its flora has resulted from her examination of the British Museum Herbarium, and her naming of the admirable collection made by Mr. Boodle, and also those made by Mr. Scott Elliot and Mr. Tyson. The most noteworthy observation on these aggregates is the proportion of species to genera. In the warm Atlantic the genus averages well over 5 species; in the Indian Ocean the proportion is nearer 4 than 3 species to the genus; while at the Cape it is almost exactly 3. This is instructive when we remember, as I have elsewhere pointed out,* that while the Arctic Algæ average slightly more

* Trans. Biol. Soc. Liverpool, vol. v., p. I77. 
than 2 species only to the genus, the West Indies and Australia average rather more than 5 and less than 5 respectively. I estimate that the north temperate Atlantic yields an average of about $4 \frac{1}{2}$ species to the genus, and the difference between this and 3 species per genus found at the Cape is to be attributed primarily to the short coast line of the Cape, and in a less degree to its Algæ being less known. The calculation of such averages and proportions appears to me to be justified only when applied to the whole flora, and becomes more dangerous and apt to mislead when applied to portions of it, since particular groups in all the floras have been subjected to unequal treatment by collectors and describers, and we may perhaps trust to these personal errors neutralising each other when the complete totals are compared.

The warm Atlantic and Cape have 85 genera and 114 species in common, while the Indian Ocean and Cape have 86 genera and 89 species in common. That the number of genera in common should be so nearly exactly similar is interesting, and to discover whether they are the same genera in many cases it is only necessary to turn to the last table, where the Algæ common to all three regions are given to find that 72 genera are are common to all three. Some years ago I hazarded the speculation that, while the genera of the tropical Atlantic and those of the Indian Ocean were largely the same, the species were, in a high proportion, different.* We can now see that they have no less than 103 genera in common out of a total of 139 occurring in the Indian Ocean and 162 in the warm Atlantic. They have certainly more species in common, viz., I73, but these must be considered relatively to the two totals of 514 in the Indian Ocean and 859 in the warm Atlantic, when my expectation will appear to be fairly borne out. Nevertheless, I confess to having anticipated an even greater diversity of species. That the absolute number of genera occurring at the Cape should be by two greater than those of the Indian Ocean completely puzzles me. I cannot fully account for it on any theory. While the number of species in common between any two of the floras is greater than the number of genera (though in one case only three more), the number of species, as might be expected, in common to all three-vi7., 59-is less than the genera-viz., 72. Again I should have expected to find relatively fewer species in common.

When one comes to analyse these totals, the process must be carried on in a more guarded fashion. One expects, as shown above, to find fewer species to the genus at the Cape than in the tropical floras, but one hardly expects to find that the genera of Floridece at the Cape are by five 
more numerous than in the warm Atlantic, and by 15 more than in the Indian Ocean. There no less than 95 genera of Floridea at the Cape, with 295 species, while the 90 of the warm Atlantic contain nearly 200 more species! Matters are much the same in the case of the Phaophycea, and we have to come to the Chlorophycece to redress the balance in the case of the warm Atlantic. They just fail to bring it level in the case of the Indian Ocean. It has been remarked above that the genera which the two tropical floras have in common with the Cape are almost identical in number. The analysis shows that the figures are very steady, viz., 58 each of Floridee, I4 and I 5 of Pheopliycee, I I each of Chlorophycee, and 2 each of Protoplycee. The table shows the tropical character of such a group as the Siphonee very markedly. There are 99 species in 23 genera in the warm Atlantic, 72 species in 16 genera in the Indian Ocean, and only 20 species in 7 genera at the Cape. It is interesting to observe that the whole of the I6 genera of Siphonece in the Indian Ocean are represented in the warm Atlantic. It has no peculiar generic type of its own in this tropical group. While the genera of this tropical order are thus practically identical, the species are in a very high proportion different. Only 29 are possessed in common out of the two totals of 99 and 72 . In the comparison of the two tropical floras there is the coincidence that the genera and species of Siphonee agree exactly in numbers, viz., I6 and 29, with the total of all the Phaophycee-a thing without significance, however. But I need not go farther into the details of the table.

The interest that is attached to the above comparison is mainly this. We have here two tropical marine floras cut off from each other by a permanent continental area, and communicating only viâ the Cape. That these floras have been periodically mingled at the epochs of warmer climate at the Cape seems a reasonable conclusion with regard to a group of such antiquity as the Algæ, and the proportions of species in common and genera in common between the different regions, and among all three may have a significance in this respect to students of distribution ( $c f$. the totals of Siphonea, a peculiarly tropical order). I have elsewhere* commented on the fact that, 'while in the Arctic and Australian regions the Phaoplyyee far outnumber the Chlorophycea, in the tropical West Indian flora the proportion is very markedly reversed, and the green Algx outnumber the olive-brown. One is tempted to put this down to the strong illumination of the tropical sea, but another reason is to be found in the fact that a number of the Antilles richest as regards Algx are subject to irruptions of fresh and brackish water

* Trans. Biol. Soc. Liverpool, vol. v., p. 178. 
from the Orinoco floods-a condition that would operate in the same direction.' We can now check this speculation by a comparison with the figures for the Indian Ocean, mainly derived from such localities as the Red Sea, Ceylon, Mauritius, \&c., in no case affected by the question of fresh-water floods. The figures for the Indian Ocean are very nearly the same for both groups-24 genera and II 7 species of Phcooplyycere, and 26 genera and I2I species of Chloroplycee - thus showing indirectly that the irruptions of fresh water are, in all probability, potent in the case of the West Indian Algæ. One is much struck by the strength of illumination of the bottom in a shallow coral sea, but the filtering action by sea water of the rays of light, and the interception first of those rays that are most efficient in the work of assimilation-conditions modifying the pigments of Algæ-are the same in all seas.* The practically tideless character of the Antilles would also make for a preponderance of green over olive-brown forms.

George Murray.

* Recent research on other pigments by Prof. Marshall Ward makes it appear to me more probable that, in the case of the marine Algæ, the pigments are rather shields against the excess of blue rays than adaptations to heighten the succeptibility of chlorophyll to the diminished supply of the others. 


\begin{tabular}{|c|c|c|c|c|c|c|c|c|c|c|c|c|c|c|}
\hline \multirow{3}{*}{$\begin{array}{l}\text { Algie. } \\
\text { Floridice. }\end{array}$} & \multicolumn{6}{|c|}{ TOTALS. } & \multicolumn{8}{|c|}{ ALGÆ COMMON TO } \\
\hline & \multicolumn{2}{|c|}{$\begin{array}{c}\text { Warm } \\
\text { Atlantic. }\end{array}$} & \multicolumn{2}{|c|}{$\begin{array}{l}\text { Cape of } \\
\text { Good } \\
\text { Hope. }\end{array}$} & \multicolumn{2}{|c|}{$\begin{array}{l}\text { Indian } \\
\text { Ocean. }\end{array}$} & \multicolumn{2}{|c|}{$\begin{array}{c}\text { Warm } \\
\text { Atlantic } \\
\text { and Cape. }\end{array}$} & \multicolumn{2}{|c|}{$\begin{array}{c}\text { Indian } \\
\text { Ocean } \\
\text { and Cape. }\end{array}$} & \multicolumn{2}{|c|}{$\begin{array}{l}\text { Warm } \\
\text { Atlantic } \\
\text { and Indian } \\
\text { Ocean. }\end{array}$} & \multicolumn{2}{|c|}{$\begin{array}{l}\text { Warm } \\
\text { Atlantic, } \\
\text { Indian } \\
\text { Ocean, } \\
\text { and Cape. }\end{array}$} \\
\hline & Gen. & Spec. & Gen. & Spec. & Gen. & Spec. & Gen. & Spec. & Gen. & Spec. & - Gen. & Spec. & Gen. & Spec. \\
\hline Ceramieæ ............ & 6 & 47 & I I & 33 & 7 & 21 & 4 & 7 & 8 & 7 & 5 & IO & 5 & 5 \\
\hline Cryptonemiaceæ ... & 9 & 30 & 6 & I I & 5 & I6 & 3 & I & 3 & 2 & 5 & 4 & 3 & I \\
\hline Gigartineæ............ & IO & 28 & 7 & 42 & 6 & I 8 & 7 & 8 & 6 & 8 & 6 & 6 & 6 & 4 \\
\hline Spyridiex ........... & I & 6 & I & 4 & I & 3 & I & 2 & I & 2 & I & 3 & I & 2 \\
\hline Dumontiaceæ $\ldots . .$. & o & o & I & I & o & o & o & o & o & o & o & o & o & o \\
\hline Areschougiex ...... & I & I & o & o & o & o & 0 & o & o & o & o & o & o & o \\
\hline Champieæ ............ & 2 & 7 & I & 2 & 2 & 7 & I & o & I & I & 2 & 3 & I & o \\
\hline Rhodymeniaceæ ... & 6 & 22 & 7 & I 8 & 5 & IO & 4 & 2 & 4 & 2 & 3 & 2 & 2 & I \\
\hline Squamarieæ ......... & 2 & 3 & I & 4 & I & 2 & I & I & I & o & I & o & I & 0 \\
\hline Hildenbrandtiacex & o & 0 & I & I & 0 & o & I & o & o & o & O & o & O & o \\
\hline Porphyraceæ ......... & 2 & 6 & 2 & 6 & 2 & 6 & 2 & 2 & 2 & I & 2 & I & 2 & o \\
\hline Sphærococcoideæ... & 4 & 63 & 7 & I3 & 6 & 22 & I & 2 & 2 & 2 & 2 & 7 & I & 2 \\
\hline Delesserieæ ......... & 3 & 8 & 6 & 17 & 2 & 3 & 2 & 2 & I & 0 & 2 & I & I & 0 \\
\hline Helminthocladiaceæ & 6 & $4 \mathrm{I}$ & 3 & 5 & 6 & 24 & 3 & 4 & 2 & o & 4 & IO & 2 & 0 \\
\hline Chætangieæ ......... & 2 & 2 & 2 & 4 & 2 & 2 & I & I & 2 & I & I & I & I & I \\
\hline Gelidieæ.............. & 5 & 17 & 5 & 13 & 2 & 12 & 3 & 5 & 2 & 5 & 2 & 3 & 2 & 3 \\
\hline Hypneaceæ ......... & 2 & 22 & 2 & 8 & 2 & 12 & 2 & 4 & I & 2 & I & 9 & I & 2 \\
\hline Solierieæ $\quad . . . . . . . . .$. & 4 & I2 & 4 & 5 & 3 & 6 & 3 & 2 & 3 & I & 2 & 2 & 2 & I \\
\hline Wrangelieæ ......... & I & 2 & I & I & I & I & I & o & I & o & $\mathrm{O}$ & o & I & $\mathrm{O}$ \\
\hline Chondrieæ......... . & 2 & 25 & 2 & 15 & 2 & I6 & I & 8 & I & 6 & 2 & 8 & I & 5 \\
\hline riea......... & I & I & I & I & I & 2 & I & o & I & o & I & o & 0 & 0 \\
\hline Rhodomeleæ ......... & i 4 & 96 & I 5 & 43 & I 8 & 48 & 9 & 7 & 10 & 3 & 12 & I 2 & 8 & I \\
\hline Corallinea .............. & 7 & 43 & 9 & 48 & 6 & 24 & 7 & 16 & 6 & IO & 5 & 12 & 5 & 6 \\
\hline Total ......... & 90 & 482 & 95 & 295 & 80 & 255 & $5^{8}$ & 73 & $5^{8}$ & 53 & 59 & 94 & 46 & 34 \\
\hline
\end{tabular}

\section{Phaophycea.}

\begin{tabular}{|c|c|c|c|c|c|c|c|c|c|c|c|c|c|c|}
\hline Fucaceæ............... & 4 & 38 & 7 & $2 \mathrm{I}$ & 4 & 59 & 4 & 7 & 3 & 8 & 3 & IO & 3 & 4 \\
\hline Dictyotaceæ ......... & 7 & 45 & 4 & $2 I$ & 7 & 23 & 4 & 9 & 4 & 5 & 4 & 9 & 4 & 5 \\
\hline Splachnidiaceæ...... & o & o & I & I & o & o & o & o & o & o & O & 0 & o & O \\
\hline Ectocarpaceæ ...... & I & 15 & I & 5 & 2 & 12 & I & 2 & I & I & I & 2 & I & I \\
\hline Sphacelariaceæ...... & 2 & 4 & 3 & 6 & I & 5 & I & I & I & 2 & I & I & I & I \\
\hline Chordariaceæ $\quad . . . .$. & 6 & 9 & 4 & 6 & 5 & 7 & 2 & 2 & 3 & 3 & 3 & 2 & 2 & 2 \\
\hline Punctariaceæ......... & I & I & I & 2 & I & I & o & o & I & I & 0 & o & o & O \\
\hline Arthrocladiaceæ ... & I & 3 & o & $\mathrm{O}$ & I & 2 & O & o & o & $\mathrm{O}$ & I & 2 & 0 & O \\
\hline Sporochnacea ...... & 3 & 9 & I & 4 & 2 & 7 & I & 2 & I & I & 2 & 3 & I & I \\
\hline Laminariea .......... & 0 & 0 & 5 & 9 & $\mathrm{o}$ & 0 & 0 & 0 & 0 & 0 & 0 & 0 & 0 & $\mathrm{o}$ \\
\hline Ralfsieze............... & I & I & I & I & I & I & I & o & I & o & I & o & I & $\mathrm{O}$ \\
\hline Total............... & 26 & I 25 & 28 & 76 & 24 & I I 7 & I 4 & 23 & I 5 & 2 I & I6 & 29 & I 3 & I4 \\
\hline
\end{tabular}

Chlorophycea.

\begin{tabular}{|c|c|c|c|c|c|c|c|c|c|c|c|c|c|c|}
\hline $\begin{array}{l}\text { Siphoneæ } \ldots . . . . . . . \\
\text { Conferveæ } . . . \ldots \ldots \ldots \\
\text { Ulveæ.................. }\end{array}$ & $\begin{array}{r}23 \\
4 \\
5\end{array}$ & $\begin{array}{l}99 \\
80 \\
20\end{array}$ & $\begin{array}{l}7 \\
3 \\
4\end{array}$ & $\begin{array}{l}20 \\
23 \\
\text { I I }\end{array}$ & $\begin{array}{r}16 \\
8 \\
2\end{array}$ & $\begin{array}{l}72 \\
39 \\
10\end{array}$ & $\begin{array}{l}6 \\
3 \\
2\end{array}$ & $\begin{array}{l}7 \\
5 \\
6\end{array}$ & $\begin{array}{l}6 \\
3 \\
2\end{array}$ & $\begin{array}{l}7 \\
3 \\
5\end{array}$ & $\begin{array}{r}\text { I6 } \\
4 \\
2\end{array}$ & $\begin{array}{r}29 \\
13 \\
4\end{array}$ & $\begin{array}{l}6 \\
3 \\
2\end{array}$ & $\begin{array}{l}6 \\
2 \\
3\end{array}$ \\
\hline Total ................ & 32 & I99 & I 4 & 54 & 26 & I 2 I & I I & I 8 & I I & I 5 & 22 & 46 & I I & I I \\
\hline Protophycea. & I 4 & $5 \mathrm{I}$ & 4 & 4 & 9 & 21 & 2 & 0 & 2 & 0 & 5 & 4 & 2 & 0 \\
\hline Aggregate ............. & 162 & 859 & I 4 I & 429 & I39 & $5 \mathrm{I} 4$ & 85 & I I 4 & 86 & 89 & IO3 & 173 & 72 & 59 \\
\hline
\end{tabular}





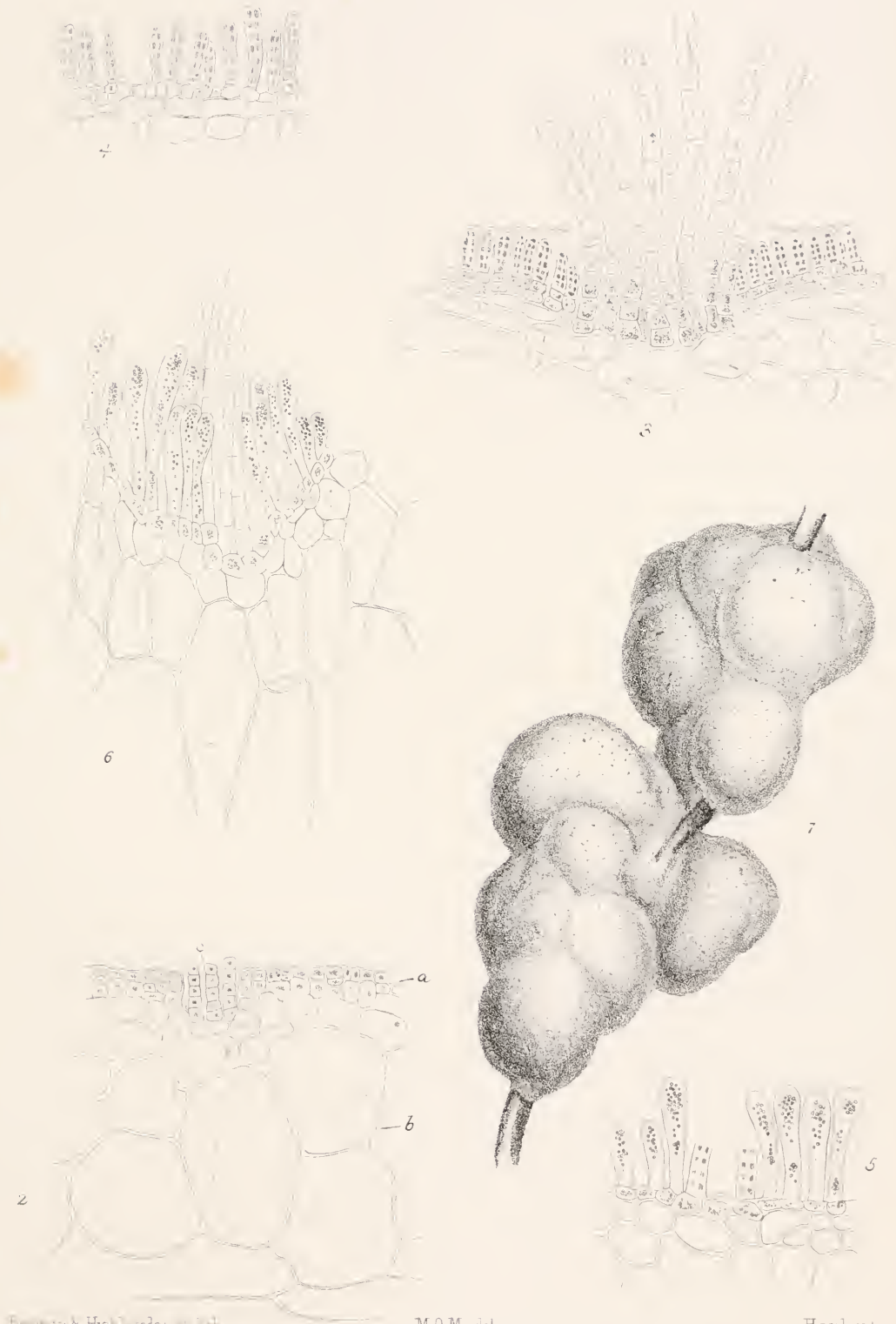


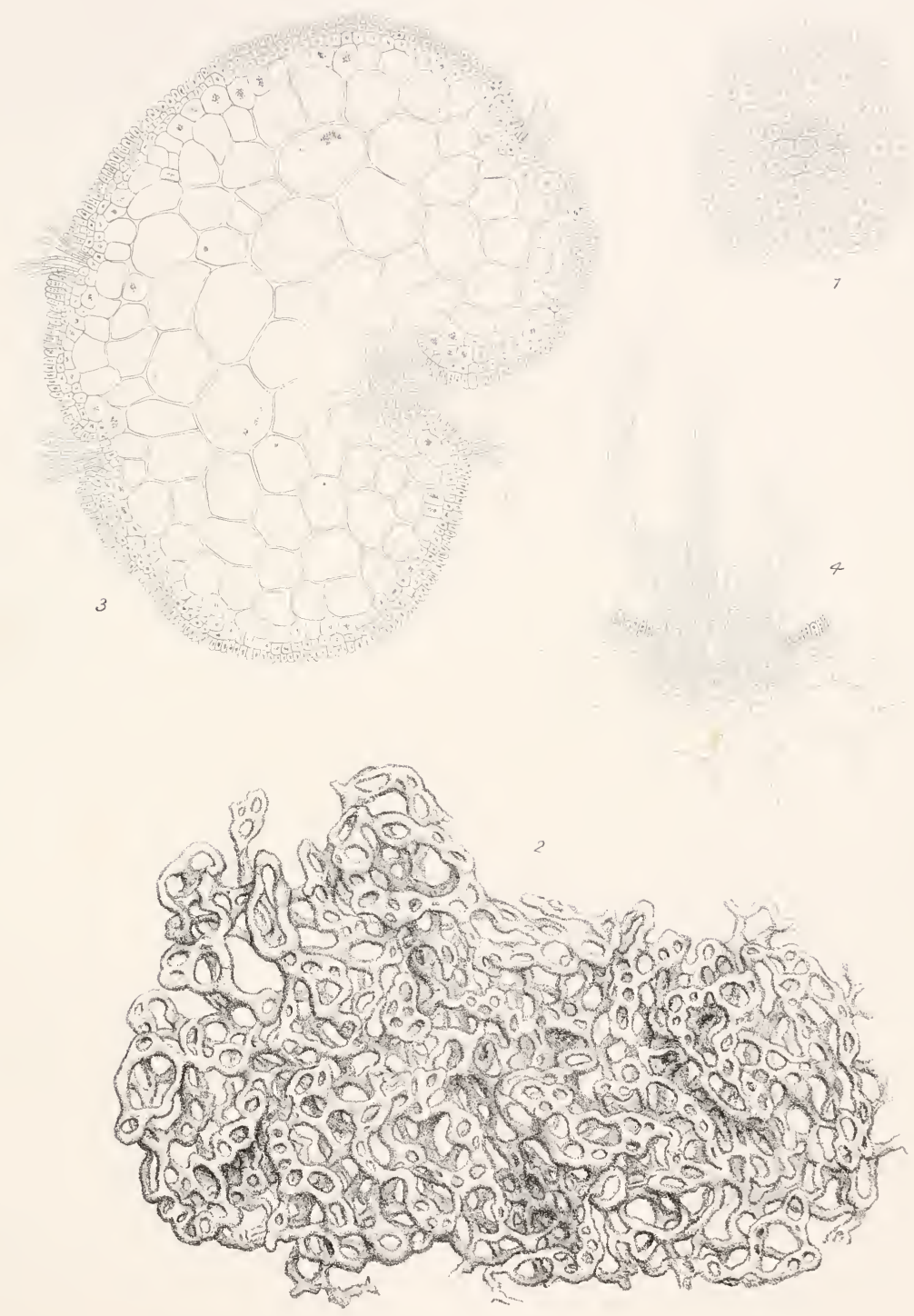

0 



\section{XII.}

\section{A NEW PART OF PACHYTHECA.}

A PAPER by Sir Joseph Hooker, in the Annals of Botany (vol. iii., I 889), gives the history of this remarkable and very puzzling fossil from the Devonian rocks, while a study of its structure by Mr. Barber will be found in two papers, one in the volume cited, the other in vol. v. A note on the subject by Mr. Thiselton-Dyer appeared also in the latter volume. The most ample discussion of the subject has not left us with any clear idea of what Pachytheca may be, and this is certainly the fault of the inadequate nature of the evidence it presents rather than any lack of ingenuity on the part of those who have sought to interpret it. The discovery of an addition to this evidence in the form of a new part of the fossil therefore raised my hopes greatly of finding some clue to its true character. I am bound to confess at the outset that, in my understanding of the matter, the discovery of this new part only adds to the perplexities of the subject, and deepens the gloom that already surrounds Pachytheca. It is, however, my duty to make this new evidence known, and I do it in this place, not out of a conviction that Pachytheca is an Alga, but because, if it be a plant at all, it is most probably an Alga, and in any case there is no evidence to justify us in placing it elsewhere.

Mr. John Storrie of Cardiff, who has done so much to further the study of Pachytheca, sent to Mr. Carruthers the cup-like structure, with a Pachytheca in it, which forms the new part about to be described. He says, in the letter with which it was forwarded, that the specimen was quite loose in its cavity, and that it 'was held in the cup like an acorn; or a growth of some arillus-like structure took place round it externally.' Mr. Storrie cut two sections of the sphere, and he describes them in his letter as follows: "The section across the ends of the outer tubes I made from a piece that I thought looked slightly different from the remainder of the outer skin, and, as I think, had been connected with the cup at one time. Part of it still 
remains in the original state ..... Please notice the shiny black external coating still remaining on one part of the Pachytheca' (plate XvIII., fig. I). Mr. Storrie thought that this shiny outer layer would repay cutting through. I may say at once that the sections cut for me of the remainder of the Pachytheca-sphere have revealed nothing new whatever, not even the section which passed through the outer coat just mentioned (plate XVIII., fig. 3). The sections (plate XVIII., figs. 2 and 3 ) have been useful only in determining beyond question the fact that it is a true Pachytheca which rested within the cup.

The cup surrounded one half of the sphere 'like an acorn,' as Mr. Storrie says, or as an egg-cup holds an egg. On the outside, the cup is clothed with hairs (plate XVII., figs. I, 3 and 4) on the lower portion, and is otherwise smooth. The broken edge (plate xviI., fig. 2) shows that the cup itself is chambered radially and these chambers appear to spring from an axial body the top of which may be seen in the bottom of the cup (plate xviI., figs. 2 and 3). My first idea was that this projecting axis would be found to correspond with the dimple found in many specimens of Pachytheca, but this portion was not among the parts sent by Mr. Storrie; probably it was the part he used in making his two sections. However likely such a view may be, I have no evidence of it. Unfortunately the structure of the interior of the cup, as seen in vertical section, has not been preserved, and a microscopical examination of it reveals only purely mineral structure. We know, however, from examining its broken edge, that the cup was radially chambered, like the sporangial rays of Acetabularia, and in fact the cup itself (without the Pachytheca-sphere) is not unlike the remains of some organism like Acetabularia, and the resemblance is heightened by the axial body in the centre. Suggestions of this kind are, however, plainly of no use, since in none of the verticillate Siphonece is there anything to correspond with the sphere of Pachytheca. There is, in fact, no alga, nor any other plant known to me, which lends itself for comparison with Pachytheca.

Since the Pachytheca-sphere was loose in the cup, there must have been a tissue, now perished, between the ends of the radiating filaments of the sphere and the chambers of the cup. My only hope of gaining farther light is in the discovery of specimens in which this tissue has been preserved, and more of the cup and axial portion-or that perhaps, in the mean time, some zoologist may recognise it, and relieve botanical literature of this standing puzzle.

I am much indebted to Mr. John Storrie, who found this unique specimen and to Mr. Carruthers for the opportunity he kindly gave me of making it known.

George Murray. 


\section{EXPLANATION OF PLATES.}

\section{Plate XVII.}

Fig. I. Side view of cup of Pachytheca $(\times 14)$.

Fig. 2. The same from above $\left(x_{14}\right)$.

Fig. 3. The same in vertical section $(\times 25)$.

Fig. 4. Hairs from the lower part of outside of $\operatorname{cup}(\times 6 r)$.

Fig. 5. $a$. The cup natural size, 5. $b$. The cup natural size, showing how the Pachytheca-sphere rested in it.

\section{Plate XVIII.}

Fig. I. Pachytheca-sphere (from cup) showing portion of shiny outer layer ( $\times$ I 4 ).

Fig. 2. Section through portion of same $(\times 55)$.

Fig. 3. Section through another (marginal) portion, including shiny outer layer $(\times 86)$.

Fig. 4. Tangential section through another Pachytheca-sphere ( $\times$ I 25$)$.

Fig 5. Portion of same $(\times 375)$.

Fig. 6. Diagrammatic section through sphere and cup.

Note. -Figs. 4 and 5 (plate XviII.) are from a section sent me by Mr. Storrie. They were cut from a Pachytheca obtained from the same bed as the one described. The section is tangential near the periphery, but a portion of the central core is shown. Fig. 5 shows both central and peripheral tissues, and the arrangement of the peripheral tubes shows inconsistencies with any known plant structure, a condition which may or may not be due to their state of preservation. For example, the tubes cut transversely sometimes appear between those cut obliquely, and sometimes within them, even under the most careful focussing. 


\section{XIII.}

\section{CALCAREOUS PEBBLES FORMED BY ALGAE.}

Mr. E. GROve has been good enough to give me several large calcareous pebbles collected by Dr. J. W. Velie, Secretary of the Chicago Academy of Sciences, who found them in a pond in Michigan. Mr. B. W. Thomas, of Chicago, had sent them to Mr. Grove with a request for his opinion as to their nature, and Mr. Grove forwarded them to me. I am indebted to Mr. Thomas for a further supply. The pebbles were found resting free on a sandy bottom under three to eight feet of clear water in a pond separated from Lake Michigan by a sand bar. The specimens vary in size from an inch to three inches and a half in diameter, are hollow in the interior and show a stratified or concentric zoned structure. On decalcifying a portion of one, I found that it was composed of a densely interwoven mass of filaments evidently not all of the same nature, but the predominating kind was clearly a species of Schizothrix, while mixed with it there were other forms, notably filaments of Stigonema and Dichothrix. I examined portions here and there from a number of the pebbles, and in all cases found the strong stout sheaths and filaments of Schizothrix composing by far the greater part of the decalcified mass. At the surface the Schizothrix filaments had been clearly alive when the pebbles were gathered, while nearer the centre older sheaths only were found. It was apparent that the Schizothrix died off internally while fresh crops were produced on the surface adding to the growth of the pebble. On comparing this Schizothrix with the figures and description in M. Gomont's admirable Monographie des Oscillaricées, I found a difficulty in identifying it, but none in placing it near certain other species. I accordingly consulted him, and he had no hesitation in identifying Schizothrix fasciculata 
Gomont in the mass I sent him. At the same time he says, 'The interior of the calcareous mass is formed of entangled filaments; they appear to belong to a Schizothrix, but which ?' It was precisely these sheaths that had puzzled me, and I had been inclined to regard them as those of an unknown Schizothrix. They do not agree very closely with the figures given of $S$. fasciculata, but M. Gomont finally says, 'I do not think one can make anything very distinctly out of this specimen, except S. fasciculata, which undoubtedly occurs in abundance.' I have figured the specimen selected by M. Gomont and others on plate XIx., figs. 5 a and $b$, and have given an indication (fig. 4) of the density with which the filaments are interwoven.

S. fasciculata is known from the countries of central Europe and forms small, stony cushion-like calcareous masses. The filaments are always entangled where they are incrusted, but on the surface, where they are more or less free, there is very little entanglement and the filaments are almost straight and parallel. The ordinary incrustation formed by this species is said to be zoned in section, and its surface is generally mammillate. It is constantly found growing in association with other Algæ of the same group, and there is a considerable colony of them in the present instance. The most striking feature, however, in this respect is the large number and variety of diatoms present in the mass. Mr. E. Grove has made an exhaustive examination of them, and has most kindly furnished me with the appended list of them, which extends to about 90 species and varieties.

A matter of particular interest is the massive occurrence of carbonate of lime in association with a kind of organism that is commonly so incrusted only in hot springs, and to some extent it raises the question of the influence of temperature on the deposition of carbonate of lime. Murray and Irvine have made a series of most interesting experiments leading to the conclusion stated by Murray (Challenger ReportsSummary of Results, p. 1456) as follows :-

'The very slight development of carbonate of lime shells and other carbonate of lime structures in the cold waters of the polar regions are instructive when recalled in connexion with the massive coral reefs constructed in the polar regions in Palæozoic and even later geological times. The waters of the ancient oceans must have had a temperature of $65^{\circ}$ or $70^{\circ} \mathrm{F}$. at the poles, for it has been shown that the deposition of carbonate of lime is due to the secretion of carbonate of ammonia, one of the effete or waste products of marine animals, which, decomposing the soluble sulphate of lime in sea-water, produces insoluble carbonate of lime to form shells, its precipitation taking place with great difficulty and very slowly in cold water, but easily and very rapidly within the organism in 
water of a high temperature; hence in the cold polar and deep sea waters of our day no massive carbonate of lime shells or other structures are secreted by organisms.' Although plainly to be otherwise accounted for, it is interesting to observe that the coralline plants of the sea are much more massively developed in the warmer seas than in the colder ones. In fresh waters it would be interesting to know how far the incrustation of Characea, for example, is affected by temperature. Certainly, in the particular case under discussion, the massive occurrence of carbonate of lime suggests a hot-spring Alga rather than one living at the temperature of a lake in Michigan. The incrustation of carbonate of lime so often found on the surface of plants is, no doubt, often due to the evaporation of water holding the salt in solution, which has been excreted by the plant; but, as Vines (Lectures on the Plyysiology of Plants, p. 22) suggests, 'in the cases of subinerged plants it is possible that the calcium carbonate may be deposited on the surface in consequence of the absorption of carbonic acid from the water by the plant.' Since a relatively high temperature would encourage this operation of dissociation, it is exceedingly probable that we have in such a process an explanation of this distribution of carbonate of lime deposits according to temperature. Gomont (loc. cit.) says of Oscillariece that, when they live in waters strongly charged with lime, the precipitation of carbonate of lime is caused by the decomposition of carbonic acid, and that this occurs only where the Alga do not find carbonic acid in sufficient quantity to meet the needs of vegetation. When it is abundant, as in certain mineral waters, the salt is precipitated only in very small quantities.

In the Aunals of Botany (vol. v., p. 225), Mr. Thiselton-Dyer refers to the occurrence of round calcareous pebbles in profusion at the bottom of Lough Belvedere, near Mullingar. He collected and examined these pebbles, and was much struck with their geological possibilities. 'An accumulation of them might easily form a rock, and the interpretation of its structure would not be easy.' The pebbles in this case (fig. 6) are not nearly so large as those from Michigan, and Mr. Thiselton-Dyer describes them as 'of all sizes up to that of a filbert.' He has most kindly placed at my service a number of these pebbles, and in his letter calls my attention to the resemblance of 'the material to pisolite $[=$ Pea grit of the Inferior Oolite, not the pisolite limestone of Eocene Age] though, of course, the structure is very different.' I have seen a specimen of this rock from the Cotteswolds, and it so exactly resembles the appearance that would be presented by a heap of these pebbles that I am in no way surprised at Mr. Thiselton-Dyer's insisting on the geological interest of these bodies. Those pebbles I have cut open are solid, though the substance is less dense at the 
centre, and they would form a more compact rock than the Michigan pebbles. Mr. Dyer, in a short examination of the algal contents, determined them to be a Rivularia with Scytonema, and Mr. Archer had also noted other Algæ casually interwoven in the mass. I have examined it with much care and have compared it with the Michigan specimens, and the predominant Alga is the same in both cases viz., Schizothrix fasciculata. As in the Michigan pebbles, there are a number of other Algæe casually present notably a species of Dichothrix ( $=$ Scytonema) as observed by Mr. Thiselton-Dyer, Nostoc cells, diatoms, \&c. I have found no trace of the Cladophora, nor of anything resembling one, mentioned by Mr. Barber in Annals of Botany (vol. iii., p. I44), and Mr. Thiselton-Dyer (loc. cit.) also has seen nothing to confirm the statement.

It is much to be wished that some of our Irish botanists would give an account of the growth of these bodies. They are in shallow water in both cases, and may be a product of the high temperature of summer; but speculation on this point is useless without further knowledge. $\mathrm{Mr}$. E. Grove has kindly examined the Lough Belvedere pebbles for diatoms, and his lists, 'allowing for the differences between the diatomaceous flora of North America and Great Britain, show much resemblance between the two gatherings.'

GEorge MurRay.

\section{EXPLANATION OF PLATE XIX.}

Fig. I. Pebbles from Michigan natural size.

Fig. 2. " " " "

Fig. 3. " in section " "

Fig. 4. Interwoven filaments of Schizothrix fasciculata $(\times 86)$, from Michigan pebbles.

Fig. 5. $a, b$. Filaments of pebbles $\left(a \times 23^{2} ; a^{1} \times 375 ; b \times 23^{2} ; b^{1} \times 375\right)$.

Fig. 6. Pebbles from Lough Belvedere, Mullingar. 
DIATOMACEOUS REMAINS OBSERVED IN PREPARATIONS OF CALCAREOUS ALGAE FROM A POND IN MICHIGAN.

Achnanthes delicatula, Grun. Scarce.

Achnanthidium flexellum, Bréb. microcephala, Grun. minutissima, $\mathrm{K}$.

" " var. cryptocephala, Grun.

Amphipleura pellucida, K. Rare.

Amphora ovalis var. affinis, K. Rare.

" veneta, K. Frequent.

Asterionella formosa, Hass. Rare.

Caloneis alpestris, $\mathrm{Cl}$.

" fasciata, Cl. Rare.

" obtusa, Cl. Rare. (= Nav. Hebes, Ralfs.)

Cocconeis Placentula, E.

Cyclotella antiqua, W. S.

var. lineata, Grun. Rare.

" comta var. radiosa, Grun.

" Kützingiana, Chauvin.

" Meneghiniana, $\mathrm{K}$.

Cymatopleura elliptica W. S. (A twisted form, perhaps the C. Cochlea, Brun.

Solea, W. S.

Cymbella amphicephala, Naeg.

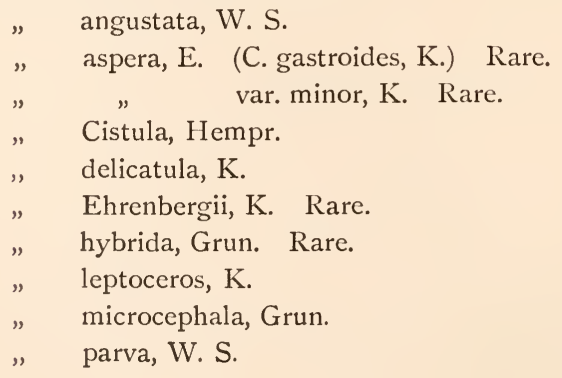


Cymbella pusilla, Grun.

, (Encyonema) Cesatii, Grun.

" $\quad$ gracilis Rab. var.? (n. sp. teste Cleve).

" $\quad$ " Triangulum, E.

" $\quad$ " turgida, Greg. Rare. " $\quad$ ventricosa, $\mathrm{K}$.

Denticula elegans, $\mathrm{K}$.

Diploneis oculata Bréb. Rare.

” ovalis, Hantzsch. Rare.

Epithemia Argus, E. Frequent.

" gibba, E.

" turgida var. granulata, Grun.

" Veliei, Thomas. Cleve notes this as E. Cistula, E. var. proboscidea, Grun., which Grunow considers the same as E. proboscidea Sm. This form is, however, much larger, and has much coarser striæ than E. proboscidea, either in Grunow's or Smith's figures.

Eunotia Arcus, E. Rare.

" prærupta, Grun.

" " var. curta, Grun. Frequent.

Fragilaria mutabilis, Grun.

" Harrisonii, Grun.

Gomphonema acuminatum, E.

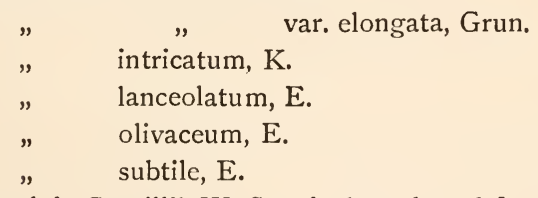

Mastogloia Grevillii, W. S. A short, broad form.

" Smithii, Thwaites var. amphicephala, Grun.

" " var, lacustris, Grun. Frequent.

Melosira crenulata var. tenuis, Grun.

Navicula bacilliformis, Grun.

brachysira, Bréb.
cincta, K.
$\quad \quad \quad$ var. Heufleri, Grun.
" $\quad$ lanceolata, K. Rare.
radiosa, K. Rare.
$\quad \quad \quad$ var. acuta, K.
" radiosa, var. tenella, Bréb.


Navicula Reinhardtii, Grun. Rare.

, vulpina, $\mathrm{K}$.

„ Zellensis, Grun. Frequent.

Nitzschia amphibia, Grun.

, angustata, Grun.

, " var. acuta, Grun.

, Denticula, Grun.

„ sinuata, var. Tabellaria, Grun.

Pinnularia major, $\mathrm{K}$.

" microstauron, E.

" Krookii, Grun. Abundant (teste Cleve).

, oblonga, K.

" viridis var. commutata, Grun.

Pleurosigma attenuatum, W. S. Rare.

Stauronis Phœnicenteron, E.

„ anceps, var. amphicephala, K. Rare.

Stephanodiscus Astræa var. spinulosa, Grun.

Synedra Chasei, Walker. minutula, Grun.

„ delicatissima, W. S.

" obtusa, W. S.

Tabellaria fenestrata, $\mathrm{K}$.

E. Grove.

DIATOMACEOUS REMAINS OBSERVED IN WASHINGS OF

CALCAREOUS ALGAE FROM LOUGH BELVIDERE, MULLINGAR, IRELAND.

Achnanthes Biasolettiana, Grun.

Clevei, Grun. Rare (teste Cleve). delicatula, Grun. Rare.

$\begin{array}{lll} & \text { delicatula, Grun. } & \text { Rare. } \\ \text { lanceolata, Grun. } & \text { Scarce. }\end{array}$

" microcephala, Grun.

" minutissima, $\mathrm{K}$.

" $\quad$ var. cryptocephala, Grun.

Achnanthidium flexellum, Bréb. 
Amphora ovalis, $\mathrm{K}$.

" $\quad$ var. affinis, Grun.

" " , Pediculus, Grun.

” salina, W. S. Rare (teste Cleve).

Caloneis alpestris, $\mathrm{Cl}$.

" bacillaris, $\mathrm{Cl}$.

" fasciata, Cl. Rare.

" Silicula, $\mathrm{Cl}$.

Cocconeis Pediculus, E. Rare.

„ Placentula, E.

" $\quad$ var. lineata, Grun.

Cyclotella comta, K.

, Kützingiana, Chauvin.

” Meneghiniana, K. (teste Cleve).

Cymatopleura Solea. Rare.

Cymbella amphicephala, Naeg.

, affinis, $\mathrm{K}$.

, aspera, E. Scarce.

" Cistula, E.

, cuspidata, K. Scarce.

" cymbiformis, E.

„ Ehrenbergii, K. Rare (teste Cleve).

„ helvetica, $\mathrm{K}$.

" , var. Balatonis, Grun.

” lanceolata, E. Scarce.

" lata, Grun.

” microcephala, Grun.

" æqualis, $\mathrm{Sm}$.

" pusilla, Grun.

” lævis, Naeg. Rare.

„ naviculiformis, Auersw. Rare (teste Cleve).

" sinuata, Grun. Rare.

" parva, Sm.

" (Encyonema) turgida, Greg. Rare.

„ ventricosa, $\mathrm{Cl}$.

" " var. ovata, $\mathrm{Cl}$.

Denticula tenuis, $\mathrm{K}$.

Diatoma lineare, $\mathrm{Sm}$. tenue, $\mathrm{K}$.

Diploneis Boldtiana, $\mathrm{Cl}$. Rare.

„ oculata, Bréb. 
Diploneis ovalis, Hantsch.

Epithemia Argus, K. Scarce.

Eunotia Arcus, E.

Fragilaria Harrisonii, Grun.

" capucina, Desm. Rare.

" intermedia, Grun.

" mutabilis, $\mathrm{Sm}$.

Gomphonema acuminatum, E.

")

"

",

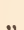

,

,

$"$

"

"

"

var. Brébissonii, Cl. Rare. angustatum K. var. Sarcophagus, Cl. Scarce. constrictum, E. Scarce. geminatum, Ag. Rare. gracile, E. Scarce. intricatum, $\mathrm{K}$.

„ var. dichotoma, Grun. olivaceum, E. subclavatum, Grun.

Mastogloia Grevillii, Sm. Scarce.

Smithii Thw. var. amphicephala, Grun. Scarce. Navicula Bacillum, E.

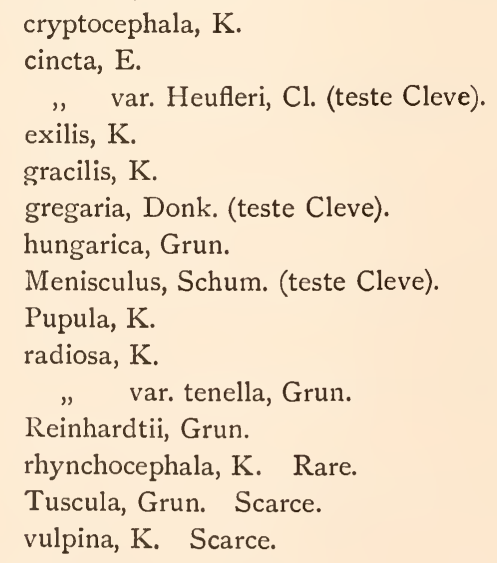

Neidium productum, $\mathrm{Cl}$. Rare.

Nitzschia amphibia, Grun.
" angustata, $\mathrm{Sm}$.
, Denticula, Grun. (Denticula obtusa, Sm.)
” dissipata, Grun. 
Nitzschia linearis, Sm.

$$
\text { " sinuata, Grun. }
$$

Pinnularia commutata, Grun.

" rupestris, Hantzsch.

" appendiculata, $\mathrm{K}$.

" subcapitata, Greg.

Rhaphoneis oregonica, E. (doubtful). Rare.

Pleurosigma attenuatum, Sm. Scarce.

Pleurostauron Smithii, Grun. One specimen seen.

Synedra delicatissima, Sm.

E. GROve 


\section{XIV.}

\section{NOTES ON THE SORI OF MACROCYSTIS AND POSTELSIA.}

THE occurrence and function of conceptacular bodies in so many genera of olive-brown Algæ is a subject that has received much attention from phycologists. Without entering on a discussion of the origin of these structures, it has seemed to us that the peculiar position of the sori in the two genera, Macrocystis and Postelsia, throws additional light on the function of conceptacles; we have found the sori in these plants confined to the furrows of the sporophyllous leaves, a position of shelter such as is afforded elsewhere by conceptacles.

The Laminariacea have been subdivided by Mr. Setchell into three groups, of which the types are Laminaria, Lessonia, and Alaria, and in that of Lessonia he has placed Postelsia and the gigantic Macrocystis. The members of the Lessonia group are characterised by the complexity of their fronds, due, in the case of Macrocystis, to unequal splitting of the growing tissue, so that, while the main growth of the thallus continues at the apex, and becomes a stem-like member, the parts that are split off develop into long narrow leaves with large air-bladders at the base. When quite young the fronds are thin and smooth, the older members become thicker and stronger, and are longitudinally wrinkled or furrowed. Along the margin spines occur, which develop after the splitting has taken place.

Rosenthal published in Flora, 1890, a detailed account of the anatomy and development of the vegetative organs of Macrocystis luxurians ( $=M$. pyrifera.) The leaves have an epidermis of one or sometimes two cells in depth. These are small, compact, and full of contents. Within this layer are the cortical cells, which become larger towards the centre of the frond, and, finally, the central tissue, which in the older leaves 
is of long thick-walled cells. Large mucilaginous canals embedded in the outer cortex occur all over the leaves.

The reproductive bodies are borne on the fertile leaves, which are produced from the base of the plant on special branches. They are much like the vegetative leaves in appearance, being long and narrow, and bordered with spines; but they are destitute of air-bladders, and are more regularly and deeply furrowed than the floating leaves.

In the various descriptions hitherto published of the fruit of Macrocystis, the sporangia have been described as occurring in irregular sori, or in patches on the lamina of the fertile leaf; but this does not seem to be an exact or adequate description. In the plant examined, $M$. pyrifera, Ag., they are confined to the depressions on either side of the furrowed leaf (plate xx., fig. I) ; they are not, however, invariably present, and the furrows may be empty for considerable spaces. The tissue of the fertile leaf resembles that of the vegetative leaf; the sporangia which arise by repeated division of the epidermal cells are stout, clubshaped bodies (plate xx., fig. 3), and are surrounded and over-topped by the dark-brown paraphyses. These also arise from the epidermal cells; they are club-shaped, but more slender than the sporangia (plate xx., fig. 3), and are full of dark-coloured contents.

The sporangia, as already stated, occur in the hollow part of the furrow in longitudinal sori. The furrows are comparatively wide at the base, and so closely pressed together that those adjacent almost touch each other (plate xx., fig. I); the outlet is further closed by a projection of the tissue of the leaf, which, from each side, bends over the sorus (plate xx., fig. 2). The cells of the epidermis and outer cortex forming the projection are elongated parallel to the surface of the leaf, and, by narrowing the entrance of the furrow, afford additional shelter and protection to the growing and ripening fruits. A section across the fertile leaf has thus the appearance of a row of conceptacles, and forcibly recalls in appearance the conceptacles of Splachnidium and other brown Algæ.

Postelsia palmaformis is, so far as is at present known, limited in its habitat to the coast of California. It is of interest to note that the Pacific Coast of North America, otherwise rich in Laminariacee, is especially characterised by the number of peculiar genera which it possesses, i.e., Dictyoneuron, Postelsia, Nereocystis, Cymathere, Pterygophora, Egregia, and Eisenia, many of them monotypic and limited to California.

The only description of Postelsia palmaformis is that given by Ruprecht (Neue oder unvollständig bekannte Pfanzen aus der nordlichen Theile des Stillen Oceans) from material collected on the shores of 
Bodega Bay, California. The plant which we have examined is in the Herbarium of the British Museum, and was collected by Dr. Anderson at Santa Cruz, California. The plant consists of a root-like member bearing an unbranched, erect, hollow stem. The stem at its apex divides into several portions, each of which bears directly, or after still further divisions, a number of stalked fronds.

The plant described and figured by Ruprecht presents some points of difference; the stem bears the stalked fronds directly from its apex without any further division, and the fronds of his plant have a toothed margin, and are larger than the smaller untoothed fronds of the specimen we have examined.

The fronds are longitudinally ribbed throughout their whole length, the ribs being most marked in the central thicker portion of the thallus, and diminishing in size towards the margins (plate xx., fig. 4.) The epidermis of the frond consists of one or sometimes two layers of small cells with coloured contents. Beneath this is the cortex, made up of roundish thick-walled cells, of only a few layers in thickness in the furrows, but forming the whole mass of the tissue of the ridges. The medullary portion consists of filaments running in an irregularly longitudinal direction forming a compact tissue.

The fronds are all sporophylls, the sporangia occurring in the following manner. At the points where the ridge bends into the furrow the epidermal cells grow out into paraphyses, and the whole furrow is lined with a dense mass of sporangia and typical Laminarian paraphyses (plate Xx., figs. 5 \& 6).

Ruprecht figures a transverse section of a frond showing the ridges and furrows into which the thallus is folded; he also describes and figures the sporangia and paraphyses, but, in mentioning their position, says only that they occur in patches near the apices of the mature leaves. He does not appear to have noticed what has seemed a point of interest to us, that, while throughout the whole frond the sporangia occur regularly in the furrows, they never occur on the ridges of the folds, a protection thus being afforded to them, by the natural structure of the thallus, almost as perfect as that of a true conceptacle.

A. Lorrain Smith.

Frances G. Whitting. 


\section{EXPLANATION OF PLATE XX.}

Fig. I. Macrocystis pyrifera. Trans. section of frond ( $x$ 10).

Fig. 2. " " Trans. section of a furrow of the fertile frond $(\times 66)$.

Fig. 3. $\quad " \quad$ Sporangia and paraphyses $(\times 450)$.

Fig. 4. Postelsia palmaformis. Trans. section of frond ( $x$ I 0 ).

Fig. 5. " " $\quad$ Trans. section of a furrow of the frond $(\times 50)$.

Fig. 6. " $" \quad$ Sporangia and paraphyses $(\times 440)$. 


\section{XV.}

\section{A COMPARISON OF THE ARCTIC AND ANTARCTIC MARINE FLORAS.}

THE general similarity, and in many cases the identity, of species of marine organisms in the Arctic and Antarctic regions have led to a very interesting analysis of the facts, and an interpretation of them by Dr. John Murray in the Summary of the Results of the Challenger Expedition. His comparison is based mainly on the marine animals, but he points out also, as confirming his argument, that the plankton Algæ are in many cases identical. 'Rhabdospheres are found only in the warmer waters of the ocean, but the Coccospheres abound in the northern and southern temperate zones; in the Arctic and Antarctic zones these calcareous unicellular Algx are replaced by species of Protococci, which are identical in the two polar regions. Many pelagic Diatoms of the Arctic and Antarctic are likewise identical.' His theoretical explanation of this remarkable fact in the distribution of organisms is of the highest interest. Speaking of carboniferous times, he holds that 'the surface temperature of the sea could not well have been less than about $70^{\circ} \mathrm{F}$., and the same temperature and the same marine fauna prevailed from equator to poles, the temperature not being higher at the equator. ..... In early Mesozoic times cooling at the poles and differentiation into zones of climate appear to have commenced, and temperature conditions did not afterwards admit of coral reefs in the polar area, but the colder, and hence denser, water that in consequence descended to the great depths of the ocean carried with it a large supply of oxygen, and life in the deep sea became possible for the first time. There have been many speculations as to how a nearly uniform temperature could have been brought about in sea-water over the whole surface of the earth in early geological ages, as well as 
to how sufficient light could have been present at the poles to permit of the luxuriant vegetation that once flourished in these regions. The explanation that appears to me the most satisfactory is the one which attributes these conditions to the very much greater size of the sun in the early stages of the earth's history-an idea first introduced into geological speculations by Blandet (Bull. Soc. Géol. de France, sér. 2, t. 25, p. $777,1867-8$ ), who likewise discussed the relations of Arctic and Antarctic faunas-together with the greater amount of aqueous vapour in the atmosphere and the greater mass of the atmosphere.' Dr. Murray holds that the pelagic Algæ, Radiolaria, and Foraminifera are probably the slightly modified descendants of a very ancient universal pelagic fauna and flora. It is quite plain that the conditions of environment of the pelagic flora are not such as to produce much variation on any theory, and accordingly, though the mass of the pelagic Algæ enormously exceeds that of the littoral Algæ, it consists, so far as we know, of few species compared with the much-varied littoral flora-in fact, the discrepancy is so great as to hardly admit of comparison at all. Similarly, zoologists have found that the mass of individuals in the pelagic fauna probably greatly exceeds that of other marine faunas, and that the species are few when compared with the organisms of the shore and shallow water. Nearly all the fossil Algæ of the early Tertiary and the Secondary rocks, and the single form known from the Devonian, are of a type found at the present time within the Tropics, and with very few exceptions confined to the warmer seas. They owe their preservation for the most part to their being calcareous, which fits into the fact of their coming from warm seas (see p. 75). Of course, we must assume that other Algæ existed, and their remains have been lost through their not being incrusted, \&c.; but yet the argument has some weight.

If, then, we test Dr. Murray's theory by an examination and comparison of the Arctic and Antarctic marine floras, we would begin by expecting a stronger agreement between the plankton floras than between the littoral floras of these regions-from the known stable character of the former, and the varied and variable character of the latter. In the following comparison there is, therefore, less agreement to be expected than from a comparison of the total plankton and littoral floras.

In order to make the comparison we have taken Kjellman's Alge of the Arctic Sea as representing the one part; and for the Antarctic we have compiled a list. The region includes Cape Horn and the Falkland Islands, Marion, Kerguelen and Heard Islands, and Lord Auckland 
and Campbell's Islands, from which we have records by Hooker and Harvey (Antarctic Voyage), by Dickie, in the Challenger and Transit of Venus (Kerguelen) Expeditions, and by Hariot in the Mission Scientifique du Cap Horn. From these sources the list has been compiled, and brought under the same system of classification as that adopted by Kjellman; and, of course, it has been tested by our knowledge of the material.

It will be seen from the totals that the number of species in the two floras is fairly even, viz., 259 in the Arctic and 269 in the Antarctic. The Arctic species are in I I genera, i.e., an average of $2 \frac{1}{3}$ species to the genus exactly. The Antarctic species are in 98 genera, i.e, very nearly an average of $2 \frac{3}{4}$ species to the genus. The average proportion of species to genera in other seas has been commented on before (p. 66). The genera common to both oceans is 56 , and the species 4I. But no less than 42 of the species here recorded as Antarctic, and not Arctic, occur in the north temperate zone. This probably means, in part, that we have drawn our Antarctic line too near the south temperate ocean. Similarly, on comparing the Arctic list with Miss Barton's Cape of Good Hope list, we find another 9 species occurring in both, but not recorded from the Antarctic. Adding these figures together, we get 92 species common to northern and southern polar and partly temperate coasts. Of these, however, 38 species occur in the intervening Tropics-are cosmopolitan, in short, and we must subtract them from the above total, yielding 54 species in common north and south of the tropical belt, and not occurring within it. Out of the two totals of 259 and 269 there are thus 54 species in common which have not been found within the Tropics. If we were to compare all the north temperate and south temperate littoral seaweeds (instead of the polar forms mixed with certain temperate forms that enter polar seas at either pole as we have done), we should run a greater risk of counting species as extra-tropical, which are probably really tropical though not recorded. Therefore it appears to us to be a more safe proceeding to deal only with polar and adjoining waters.

The tables disclose a number of interesting facts in distribution, the principal one being this, that all the genera in the list of Fucacee and Laminariacee, the largest seaweeds, are either Arctic or Antarctic-none of them are both. Some of these genera, e.g., Macrocystis, Laminaria, are found, however, on both sides of the tropical belt, and other genera not mentioned here, e.g., Pycnophycus (Fucacee) occur in both temperate belts, but all such occurrences are exceptional among the great seaweeds. Nothing, in fact, is more striking in the distribution of seaweeds than the 
change from our northern Fucacee to the Sargassa and other allied genera of the tropical belt, and then to other Fucacee again in the south temperate and Antarctic seas, these last resembling the northern forms in general facies, but yet generically distinct in most cases.

When we compare the littoral Algæ of the tropical Atlantic, viz., 859 species in 162 genera, with those of the tropical Indian Ocean, viz., 5 I 4 species in 139 genera, we get of these 173 species and 103 genera in common (see Mem. XI.)-a very considerable proportion. However, while these oceans, or rather the tropical portions of them, may have been in communication viâ the Cape by a change of climate sufficient to give a tropical or sub-tropical character to the Cape, in comparatively recent geological times, the heat barrier between the northern and southern polar seas has always been there. The cold depths of the ocean do not enter into our calculation in the case of Algæ owing to the illumination difficulty. These two polar marine floras have been separated as long as there has been climate of any sort on the globe, and out of their poor marine floras there are 54 species that occur north and south of the tropical belt, and, so far as we know, not within it. Whether this needs a new cosmical theory to account for it or not we do not pretend to say, but it appears to support Dr. Murray's other statistics, and is more significant in some respects than the agreement of the plankton Algæ, which have a more stable environment than the littoral forms.

George Murray.

ETHEL S. BARTON. 
FLORIDEAE.

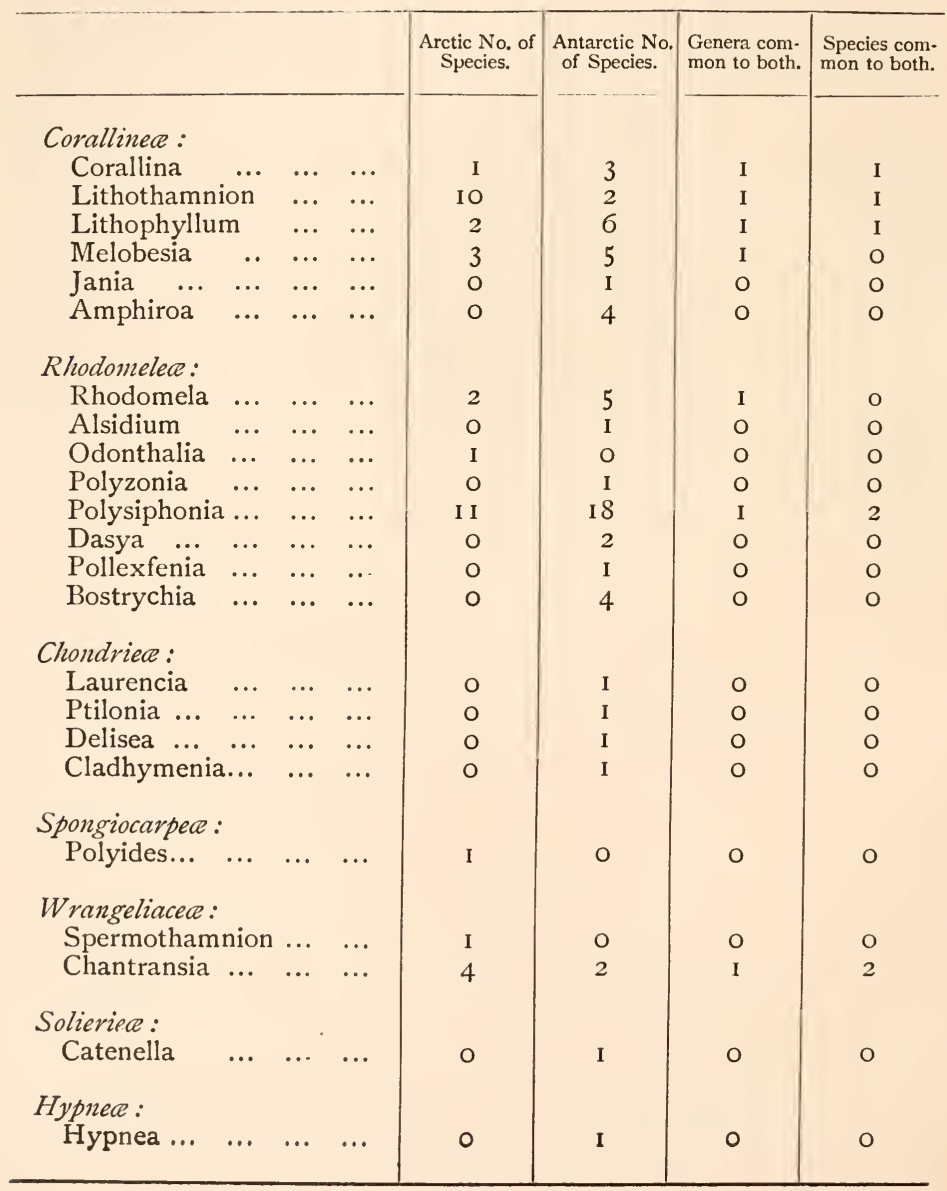




\begin{tabular}{|c|c|c|c|c|c|c|c|}
\hline & & & & $\begin{array}{l}\text { Arctic No. of } \\
\text { Species. }\end{array}$ & $\begin{array}{l}\text { Antarctic No. } \\
\text { of Species. }\end{array}$ & $\begin{array}{l}\text { Genera com- } \\
\text { mon to both. }\end{array}$ & $\begin{array}{l}\text { Species com- } \\
\text { mon to both. }\end{array}$ \\
\hline \multicolumn{8}{|l|}{ Gelidiea: } \\
\hline Choreocolax . & ... & $\cdots$ & $\cdots$ & 0 & I & O & $\mathrm{O}$ \\
\hline Gelidium & •. & $\cdots$ & $\cdots$ & 0 & $\mathbf{I}$ & 0 & 0 \\
\hline \multicolumn{8}{|l|}{ Chatangiea: } \\
\hline \multicolumn{8}{|l|}{ Delesseriea: } \\
\hline Delesseria . & & $\cdots$ & $\cdots$ & 7 & IO & $\mathbf{I}$ & O \\
\hline Nitophyllum . & $\cdots$ & $\cdots$ & $\cdots$ & I & I I & $\mathbf{I}$ & $\mathbf{I}$ \\
\hline \multicolumn{8}{|l|}{ Spharococcoidece: } \\
\hline Gracilaria & $\cdots$ & $\cdots$ & $\cdots$ & 0 & 2 & 0 & 0 \\
\hline \multicolumn{8}{|l|}{ Squamariea: } \\
\hline Hildenbrandti & & $\cdots$ & $\ldots$ & $\mathbf{I}$ & 2 & I & 0 \\
\hline Peyssonnelia . & & $\ldots$ & $\cdots$ & $\mathbf{I}$ & I & $\mathbf{I}$ & o \\
\hline Petrocelis . & & $\ldots$ & $\ldots$ & 2 & o & 0 & 0 \\
\hline Cruoria ... . & & $\cdots$ & $\ldots$ & I & 0 & 0 & 0 \\
\hline Hæmescharia & & $\cdots$ & $\ldots$ & $\mathbf{I}$ & o & o & o \\
\hline \multicolumn{8}{|c|}{ Rhodymeniee: } \\
\hline Hydrolapathu & $\mathrm{m}$ & $\cdots$ & $\cdots$ & $\mathbf{I}$ & $\mathbf{I}$ & $\mathbf{I}$ & $\mathbf{I}$ \\
\hline Rhodymenia . & & $\ldots$ & $\ldots$ & 2 & 5 & I & $\mathbf{I}$ \\
\hline Epymenia . & ... & $\ldots$ & $\ldots$ & o & 3 & 0 & 0 \\
\hline Plocamium . & ... & $\ldots$ & $\ldots$ & I & 3 & $\mathbf{I}$ & I \\
\hline Acanthococcu & & $\ldots$ & $\ldots$ & 0 & 2 & o & o \\
\hline Rhodophyllis. & $\cdots$ & $\ldots$ & $\ldots$ & I & 2 & I & 0 \\
\hline Euthora... . & $\cdots$ & $\cdots$ & $\cdots$ & $\mathbf{I}$ & 0 & o & 0 \\
\hline \multicolumn{8}{|l|}{ Champiece: } \\
\hline Chylocladia . & $\cdots$ & $\cdots$ & $\cdots$ & 2 & $\mathbf{I}$ & $\mathbf{I}$ & $\mathbf{I}$ \\
\hline \multicolumn{8}{|l|}{ Dumontiee: } \\
\hline Dumontia & $\cdots$ & $\cdots$ & $\cdots$ & $\mathbf{I}$ & 2 & $\mathbf{I}$ & $\mathbf{I}$ \\
\hline Halosaccion & $\cdots$ & $\cdots$ & $\ldots$ & 2 & O & O & 0 \\
\hline Sarcophyllis . & $\cdots$ & $\cdots$ & $\cdots$ & 2 & 0 & 0 & 0 \\
\hline \multicolumn{8}{|l|}{ Furcellariea: } \\
\hline Furcellariea & $\cdots$ & $\cdots$ & $\cdots$ & I & 0 & 0 & 0 \\
\hline \multicolumn{8}{|l|}{ Gigartinea: } \\
\hline Cystoclonium & & $\cdots$ & $\cdots$ & $\mathbf{I}$ & 0 & 0 & 0 \\
\hline Chondrus . & $\cdots$ & $\ldots$ & $\ldots$ & I & I & $\mathbf{I}$ & I \\
\hline Callophyllis . & $\ldots$ & $\ldots$ & $\ldots$ & I & 7 & $\mathbf{I}$ & 0 \\
\hline Iridæa $\ldots$ & $\ldots$ & $\ldots$ & $\ldots$ & o & 7 & $\mathrm{O}$ & O \\
\hline Gigartina . & $\cdots$ & $\ldots$ & $\ldots$ & I & 6 & I & 0 \\
\hline Phyllophora . & $\ldots$ & $\ldots$ & $\ldots$ & 3 & I & I & 0 \\
\hline Ahnfeltia & $\ldots$ & $\ldots$ & $\ldots$ & I & 2 & I & I \\
\hline
\end{tabular}


94 Comparison of the Arctic and Antarctic Marine Floras.

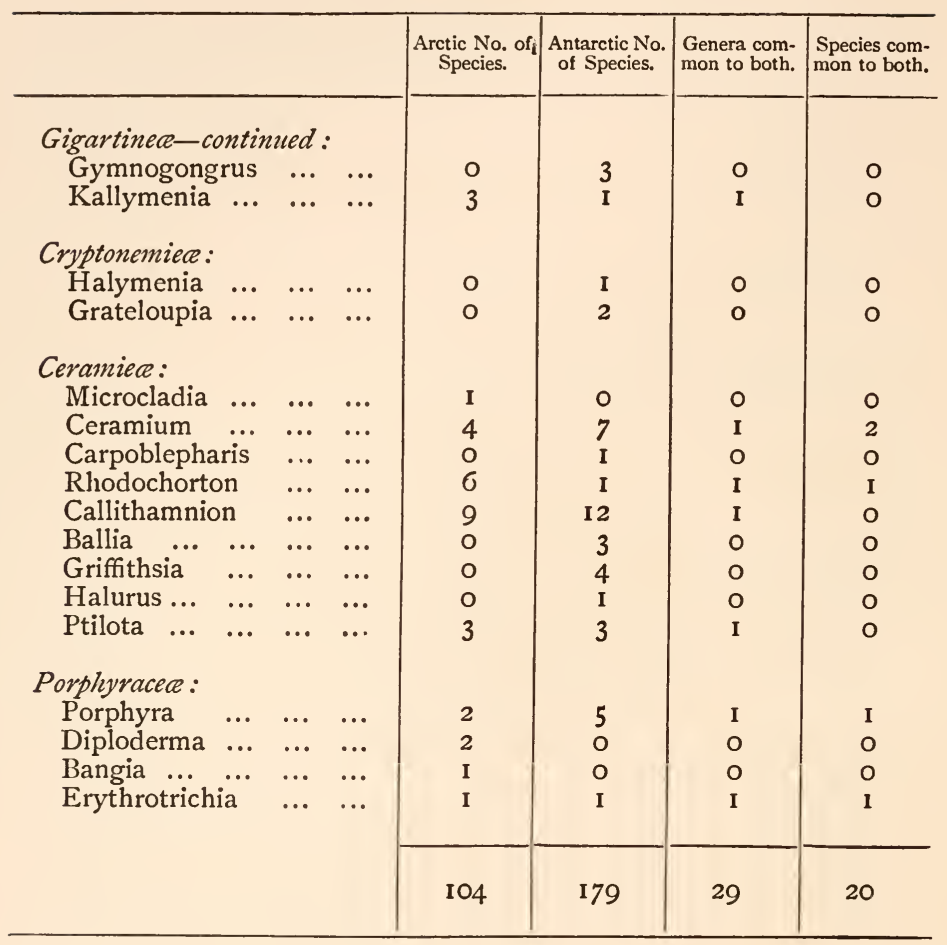


PHAEOPH YCE $A$.

\begin{tabular}{|c|c|c|c|c|c|c|c|}
\hline & & & & $\begin{array}{l}\text { Arctic No. of } \\
\text { Species. }\end{array}$ & $\begin{array}{l}\text { Antarctic No. } \\
\text { of Species. }\end{array}$ & $\begin{array}{l}\text { Genera com- } \\
\text { mon to both. }\end{array}$ & $\begin{array}{l}\text { Species com- } \\
\text { mon to both. }\end{array}$ \\
\hline \multicolumn{8}{|l|}{ Fucacee: } \\
\hline Himanthalia . & & ... & $\ldots$ & I & 0 & O & o \\
\hline Halidrys . & ... & $\ldots$ & $\ldots$ & I & 0 & o & 0 \\
\hline Ozothallia & $\ldots$ & $\ldots$ & $\ldots$ & I & O & O & O \\
\hline Fucus $\quad \ldots$ & $\ldots$ & $\ldots$ & $\ldots$ & 10 & 0 & o & 0 \\
\hline Pelvetia .. . & $\ldots$ & $\ldots$ & $\ldots$ & I & 0 & o & o \\
\hline Xiphophora & $\cdots$ & $\ldots$ & $\ldots$ & 0 & I & 0 & o \\
\hline Marginaria . & $\ldots$ & $\ldots$ & $\ldots$ & 0 & I & o & O \\
\hline Scytothalia . & $\cdots$ & $\cdots$ & $\ldots$ & 0 & I & 0 & $\mathrm{O}$ \\
\hline Durvillæa . & $\cdots$ & $\cdots$ & $\cdots$ & 0 & 2 & o & o \\
\hline \multicolumn{8}{|c|}{ Tilopteridea : } \\
\hline Scaphospora & $\ldots$ & $\ldots$ & $\cdots$ & I & 0 & $\mathrm{O}$ & 0 \\
\hline Haplospora & $\cdots$ & $\ldots$ & $\ldots$ & I & O & o & 0 \\
\hline \multicolumn{8}{|l|}{ Laminariacee: } \\
\hline Alaria... & $\ldots$ & ... & $\cdots$ & 7 & $\mathrm{O}$ & 0 & 0 \\
\hline Agarum ... & $\ldots$ & $\ldots$ & $\ldots$ & I & $\mathrm{O}$ & 0 & $\mathrm{o}$ \\
\hline Phyllaria & $\ldots$ & $\ldots$ & $\ldots$ & 2 & 0 & o & 0 \\
\hline Laminaria & $\ldots$ & $\ldots$ & $\ldots$ & I I & $\mathrm{O}$ & o & $\mathrm{O}$ \\
\hline Chorda ... . & $\ldots$ & $\ldots$ & $\ldots$ & 2 & $\mathrm{O}$ & $\mathrm{O}$ & $\mathrm{O}$ \\
\hline Adenocystis . & $\ldots$ & $\ldots$ & $\ldots$ & 0 & I & 0 & o \\
\hline Lessonia... . & $\ldots$ & $\ldots$ & $\ldots$ & 0 & 4 & $\mathrm{O}$ & o \\
\hline Macrocystis . & $\cdots$ & $\cdots$ & $\cdots$ & 0 & I & 0 & $\mathrm{o}$ \\
\hline \multicolumn{8}{|l|}{ Encoliece: } \\
\hline Stilophora & ... & ... & ... & I & $\mathrm{O}$ & 0 & $\mathrm{O}$ \\
\hline Asperococcus & & $\ldots$ & $\cdots$ & 2 & 2 & I & 2 \\
\hline Hydroclathru & & $\cdots$ & $\ldots$ & o & I & o & $\mathrm{O}$ \\
\hline \multicolumn{8}{|l|}{ Ralfsiea : } \\
\hline Ralfsia $\ldots$ & $\cdots$ & $\cdots$ & $\ldots$ & 2 & 0 & $\mathrm{O}$ & $\mathrm{O}$ \\
\hline \multicolumn{8}{|l|}{ Chordariea: } \\
\hline Chordaria & ... & ... & ... & $\mathbf{I}$ & $\mathbf{I}$ & I & I \\
\hline Mesoglœa . & ... & $\ldots$ & $\ldots$ & I & I & I & 0 \\
\hline Stereocladon. & $\ldots$ & $\ldots$ & $\ldots$ & 0 & 2 & $\mathrm{O}$ & 0 \\
\hline
\end{tabular}




\begin{tabular}{|c|c|c|c|c|c|c|c|}
\hline & & & & $\begin{array}{l}\text { Arctic No. of } \\
\text { Species. }\end{array}$ & $\begin{array}{c}\text { Antarctic No. } \\
\text { of Species. }\end{array}$ & $\begin{array}{l}\text { Genera com- } \\
\text { mon to both. }\end{array}$ & $\begin{array}{l}\text { Species com- } \\
\text { mon to both. }\end{array}$ \\
\hline \multicolumn{8}{|c|}{ Chordariea-continued: } \\
\hline Cladothele $\quad .$. & $\ldots$ & $\cdots$ & $\ldots$ & o & I & $\mathrm{O}$ & $\mathrm{O}$ \\
\hline Castagnea & $\ldots$ & $\ldots$ & $\ldots$ & I & 0 & o & $\mathrm{O}$ \\
\hline Eudesme & $\cdots$ & $\cdots$ & $\cdots$ & I & 0 & $\mathrm{o}$ & $\mathrm{o}$ \\
\hline \multicolumn{8}{|l|}{ Myrionemate: } \\
\hline $\begin{array}{ll}\text { Leathesia } & \ldots \\
\text { Elachista } & \ldots\end{array}$ & $\begin{array}{l}\cdots \\
\cdots\end{array}$ & $\begin{array}{l}\cdots \\
\cdots\end{array}$ & $\begin{array}{l}\cdots \\
\cdots\end{array}$ & $\begin{array}{l}\text { I } \\
2\end{array}$ & $\begin{array}{l}\mathrm{O} \\
\mathrm{O}\end{array}$ & $\begin{array}{l}\mathrm{O} \\
\mathrm{O}\end{array}$ & $\begin{array}{l}\mathrm{O} \\
\mathrm{O}\end{array}$ \\
\hline Myrionema .. & $\cdots$ & $\cdots$ & $\cdots$ & I & o & o & O \\
\hline \multicolumn{8}{|l|}{ Lithodemated: } \\
\hline \multicolumn{8}{|l|}{ Scytosiphonea: } \\
\hline Ilea... ... .. & $\cdots$ & $\cdots$ & $\ldots$ & I & I & I & I \\
\hline Scytosiphon .. & $\cdots$ & $\cdots$ & $\cdots$ & 2 & 3 & $\mathbf{I}$ & I \\
\hline \multicolumn{8}{|l|}{ Punctariea: } \\
\hline Punctaria & $\cdots$ & $\cdots$ & $\cdots$ & I & $\mathbf{I}$ & I & $\mathrm{O}$ \\
\hline \multicolumn{8}{|l|}{ Desmarestiea: } \\
\hline Dichloria ... & ... & $\ldots$ & $\cdots$ & I & $\mathbf{I}$ & I & I \\
\hline Desmarestia .. & $\ldots$ & $\ldots$ & $\ldots$ & I & 6 & I & $\mathrm{O}$ \\
\hline Dictyosiphon.. & $\cdots$ & $\ldots$ & $\ldots$ & 4 & I & I & $\mathrm{o}$ \\
\hline Litosiphon .. & $\ldots$ & $\ldots$ & $\ldots$ & I & 0 & $\mathrm{o}$ & 0 \\
\hline Phleospora .. & ... & $\ldots$ & $\ldots$ & 3 & 0 & 0 & 0 \\
\hline Coilonema & $\cdots$ & $\cdots$ & $\cdots$ & 2 & 0 & o & 0 \\
\hline \multicolumn{8}{|l|}{ Cutleriacee: } \\
\hline Agraozonia .. & $\cdots$ & $\cdots$ & $\cdots$ & I & 0 & 0 & O \\
\hline \multicolumn{8}{|l|}{ Sphacelariea: } \\
\hline Cladostephus & & $\cdots$ & $\cdots$ & 1 & 2 & I & I \\
\hline Stypocaulon .. & ... & $\ldots$ & $\cdots$ & I & $\mathrm{O}$ & O & $\mathrm{O}$ \\
\hline Chatopteris .. & ... & $\ldots$ & $\ldots$ & I & 0 & o & $\mathrm{O}$ \\
\hline Sphacelaria & $\cdots$ & $\cdots$ & $\cdots$ & 3 & 5 & I & $\mathrm{O}$ \\
\hline \multicolumn{8}{|l|}{ Ectocarpece: } \\
\hline Isthmoplea & ... & $\ldots$ & $\cdots$ & I & $\mathrm{O}$ & $\mathrm{O}$ & 0 \\
\hline Ectocarpus & ... & $\ldots$ & ... & 9 & 6 & I & 2 \\
\hline Actinema .. & $\cdots$ & $\cdots$ & ... & $\mathrm{O}$ & I & $\mathrm{O}$ & $\mathrm{O}$ \\
\hline Streblonema .. & $\ldots$ & $\ldots$ & ... & 0 & I & 0 & $\mathrm{O}$ \\
\hline Pylaiella... & . & $\ldots$ & $\ldots$ & 3 & $\mathrm{O}$ & $\mathrm{O}$ & $\mathrm{O}$ \\
\hline Myriotrichia . & $\ldots$ & $\cdots$ & $\ldots$ & I & $\mathrm{O}$ & 0 & 0 \\
\hline \multirow{2}{*}{\multicolumn{2}{|c|}{ Glœothamnion }} & $\cdots$ & $\cdots$ & I & $\mathrm{O}$ & 0 & 0 \\
\hline & & & & 92 & 47 & I 2 & 9 \\
\hline
\end{tabular}




\section{CHLOROPHYCEAE.}

\begin{tabular}{|c|c|c|c|c|c|c|}
\hline & & & $\begin{array}{l}\text { Arctic No. of } \\
\text { Species. }\end{array}$ & $\begin{array}{l}\text { Antarctic No. } \\
\text { of Species. }\end{array}$ & $\begin{array}{l}\text { Genera com- } \\
\text { mon to both. }\end{array}$ & $\begin{array}{l}\text { Species com- } \\
\text { mon to both. }\end{array}$ \\
\hline \multicolumn{7}{|l|}{ Ulaea: } \\
\hline Ulva $\quad \ldots \quad \ldots$ & $\cdots$ & $\cdots$ & 2 & 2 & I & I \\
\hline Enteromorpha & $\ldots$ & $\ldots$ & 7 & 2 & I & 2 \\
\hline Monostroma ... & .. & ... & 12 & I & I & I \\
\hline Prasiola ... ... & $\ldots$ & ... & I & 0 & $\mathrm{O}$ & 0 \\
\hline Diplonema $\quad .$. & $\cdots$ & $\cdots$ & I & $\mathrm{o}$ & 0 & 0 \\
\hline \multicolumn{7}{|l|}{ Confervea: } \\
\hline Chætophora ... & ... & $\ldots$ & 2 & $\mathrm{O}$ & $\mathrm{O}$ & $\mathrm{O}$ \\
\hline Spongomorpha & $\ldots$ & $\ldots$ & 3 & I & I & I \\
\hline Cladophora ... & $\ldots$ & $\ldots$ & 5 & 15 & I & I \\
\hline Rhizoclonium & $\ldots$ & $\ldots$ & 3 & 4 & I & I \\
\hline Chætomorpha & $\ldots$ & $\ldots$ & 5 & 3 & I & I \\
\hline Ulothrix $\quad \ldots$ & $\ldots$ & $\ldots$ & 3 & 0 & 0 & 0 \\
\hline Siphonocladus & $\ldots$ & $\ldots$ & 0 & I & 0 & 0 \\
\hline Urospora $\quad \ldots$ & $\ldots$ & $\ldots$ & I & I & I & I \\
\hline Bulbocoleon ... & $\ldots$ & $\ldots$ & I & o & o & 0 \\
\hline \multicolumn{7}{|l|}{ Characiea: } \\
\hline Chlorochytrium & $\ldots$ & $\ldots$ & I & I & I & I \\
\hline Characium $\ldots$ & $\ldots$ & $\ldots$ & I & $\mathrm{O}$ & $\mathrm{O}$ & o \\
\hline Codiolum $\quad \ldots$ & $\cdots$ & $\cdots$ & 3 & 0 & o & o \\
\hline \multicolumn{7}{|l|}{ Palmellea: } \\
\hline Chlorangium... & $\cdots$ & $\ldots$ & I & 0 & o & o \\
\hline \multicolumn{7}{|l|}{ Siphonea: } \\
\hline Bryopsis... & ... & $\ldots$ & I & 2 & I & I \\
\hline Derbesia & $\ldots$ & $\ldots$ & I & 0 & $\mathrm{o}$ & 0 \\
\hline \multirow[t]{2}{*}{ Codium ... $\ldots$} & $\cdots$ & $\cdots$ & o & 3 & $\mathrm{O}$ & $\mathrm{o}$ \\
\hline & & & 54 & 36 & IO & I I \\
\hline
\end{tabular}


98 Comparison of the Arctic and Antarctic Marine Floras.

PROTOPHYCEAE.

\begin{tabular}{|c|c|c|c|c|c|c|c|}
\hline & & & & $\begin{array}{l}\text { Arctic No. of } \\
\text { Species. }\end{array}$ & $\begin{array}{l}\text { Antarctic No. } \\
\text { of Species. }\end{array}$ & $\begin{array}{l}\text { Genera com- } \\
\text { mon to both. }\end{array}$ & $\begin{array}{l}\text { Species com- } \\
\text { mon to both. }\end{array}$ \\
\hline Rivularia & $\ldots$ & $\cdots$ & $\ldots$ & 2 & I & I & $\mathrm{O}$ \\
\hline Calothrix & $\ldots$ & $\ldots$ & $\ldots$ & 3 & 2 & I & 0 \\
\hline Lyngbya & $\ldots$ & $\ldots$ & $\ldots$ & I & I & I & I \\
\hline Oscillatoria & $\ldots$ & $\ldots$ & $\ldots$ & I & I & I & 0 \\
\hline Spirulina & $\cdots$ & $\cdots$ & $\ldots$ & I & o & o & $\mathrm{O}$ \\
\hline Glœocapsa & $\ldots$ & $\ldots$ & $\ldots$ & I & I & I & 0 \\
\hline \multirow[t]{2}{*}{ Dermocarpa } & $\ldots$ & $\ldots$ & $\ldots$ & o & I & O & $\mathrm{O}$ \\
\hline & & & & 9 & 7 & 5 & I \\
\hline Grand Total & $\ldots$ & $\ldots$ & $\ldots$ & 259 & 269 & 56 & $4 \mathrm{I}$ \\
\hline
\end{tabular}



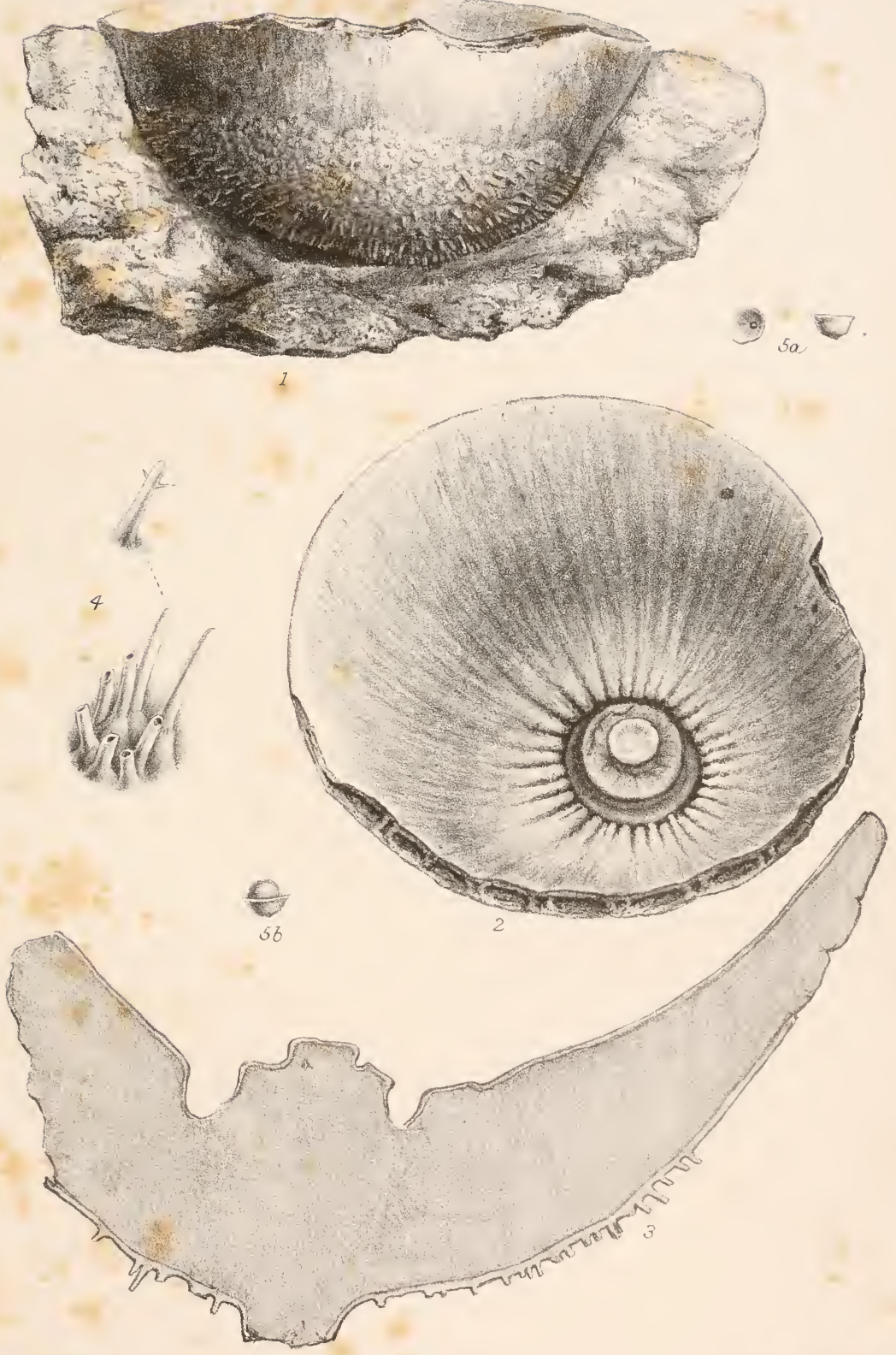


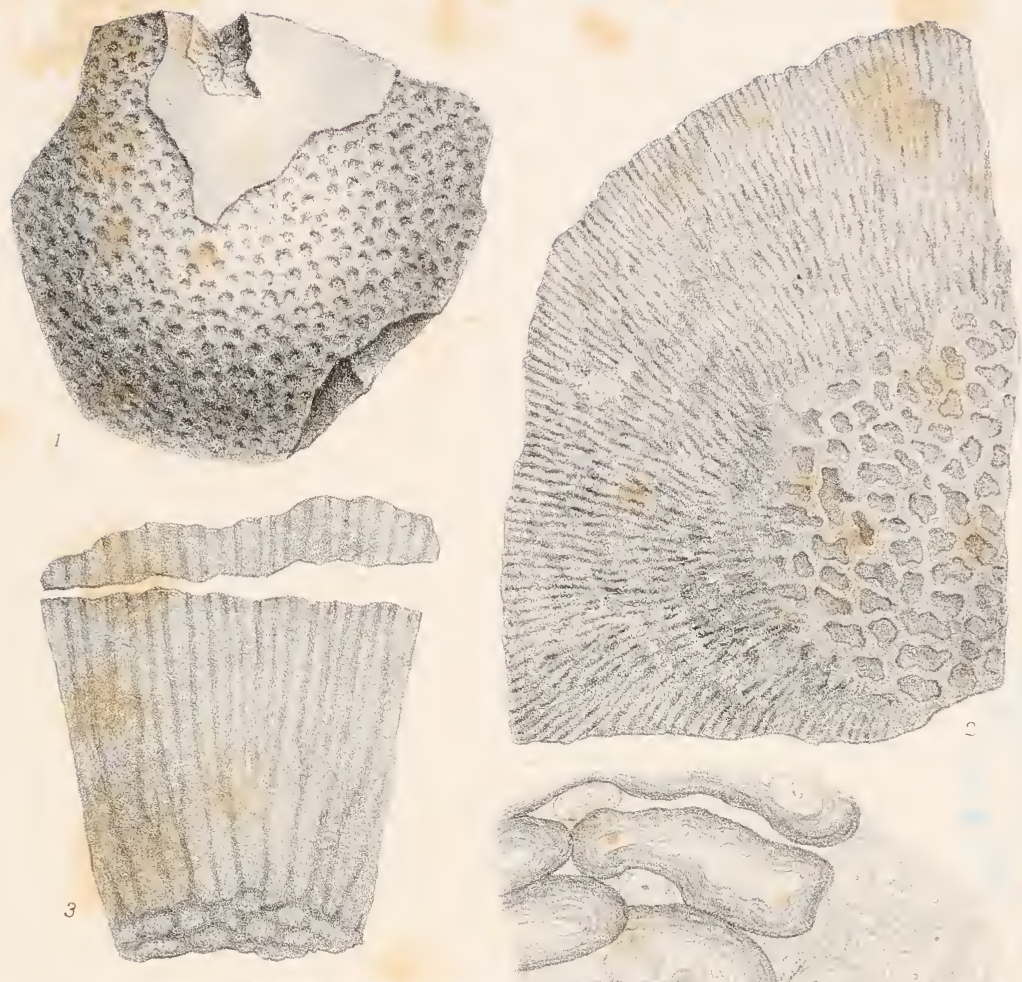

(1)

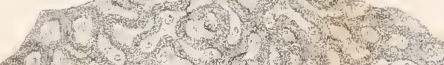

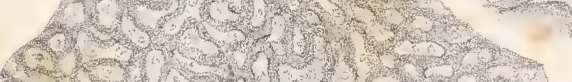

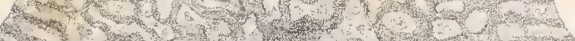

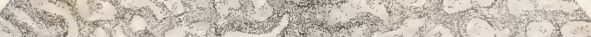

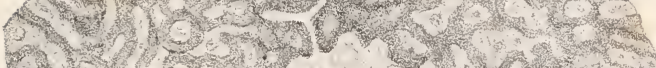

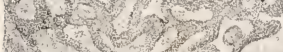

H.

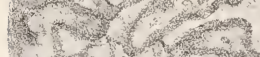

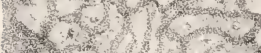

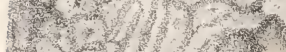

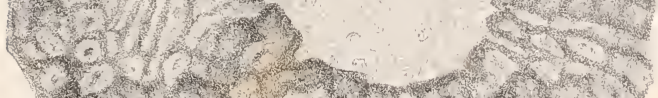
3. 3 .

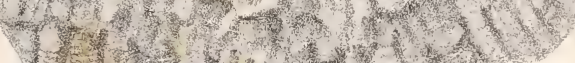

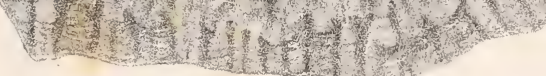

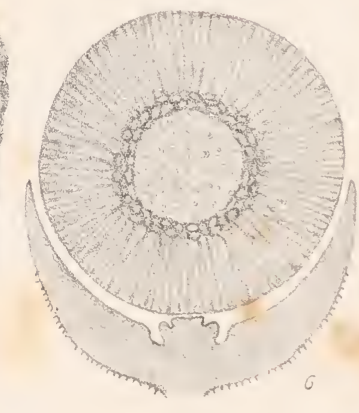




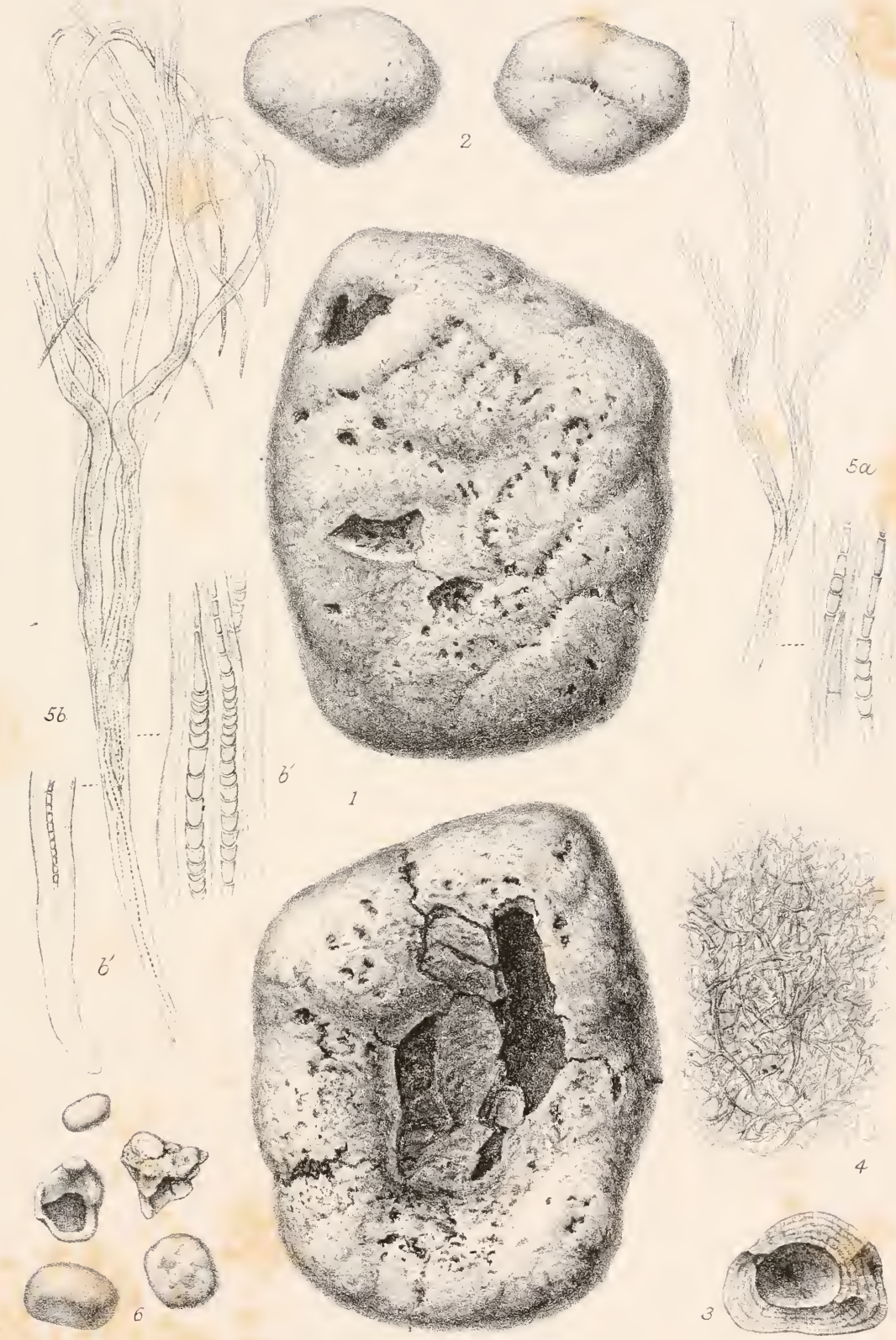



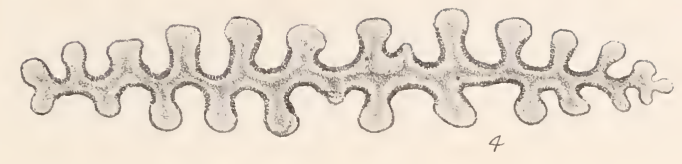

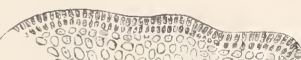
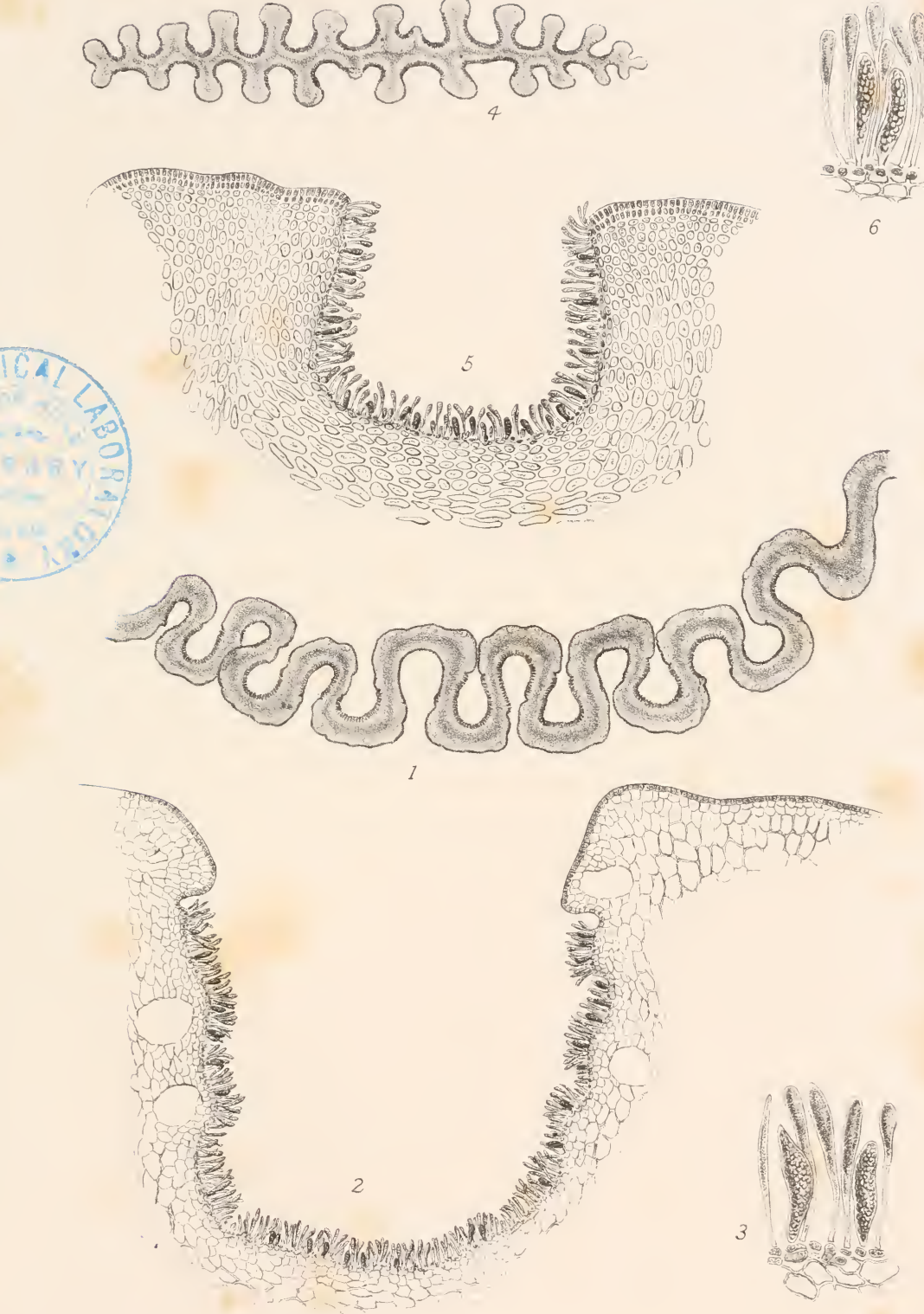



\section{PHYCOLOGICAL MEMOIRS}

BEING

RESEARCHES MADE IN THE BOTANICAL DEPARTMENT OF THE BRITISH MUSEUM.

EDITED BY

GEORGE MURRAY, F.R.S.E., F.L.S.

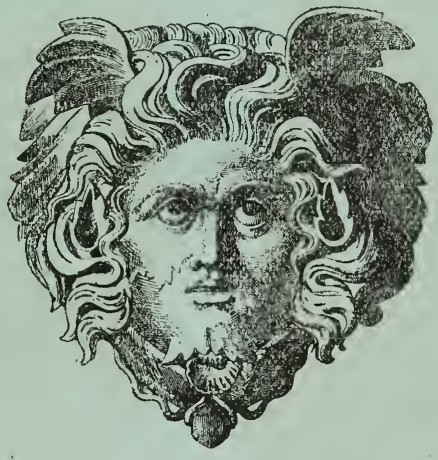

PART I.

DULAU AND CO.,

SOHO SQUARE, LONDON.

APRIL, 1892. 
The issue of the Phycological Memoirs is made for the purpose of keeping within the limits of one book the results of researches on Alge in the Department of Botany, British Museum. The publication is not a Fournal, and is not meant to compete with the numerous excellent botanical magazines. It is intended to issue Parts at about half-yearly intervals and in time to complete a Volume containing about 50 plates. In addition to the promotion of research, the authors of the Memoirs have the object of making better known the treasures of the Museum, which they have received facilities to investigate.

\section{CONTENTS OF PART I.}

I.-ON SPLACHNIDIUM RUGOSUM, GREV., THE TYPE OF A NEW ORDER OF ALGA. By Margaret O. Mitchell, former Bathurst Student, Newnham College, Cambridge, and Frances G. Whrting, former Student of Newnham College, Cambridge.

II.-ON A FOSSIL ALGA BELONGING TO THE GENUS CAU. LERPA, FROM THE OOLITE. By THE EDITOR.

III.-ON THE STRUCTURE OF DICT YOSPHARIA DECNE. By THE EDITOR.

IV.-ON MALFORMATIONS OF ASCOPHYLLUM AND DESMARESTIA. By Ethel Sarel Barton.

V.-ON CONCHOCELIS, A NEIV GENUS OF PERFORATING ALGA. By E. A. L. Batters, B.A., LL.B., F.L.S. 



\section{PHYCOLOGICAL MEMOIRS}

BEING

RESEARCHES MADE IN THE BOTANICAL DEPARTMENT OF THE BRITISH MUSEUM.

EDITED BY

GEORGE MURRAY, F.R.S.E., F.L.S.

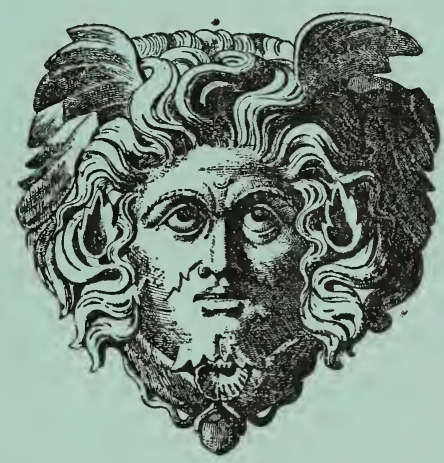

PART II.

DULAU AND CO, SOHO SQUARE, LONDON. MAY, 1893. 


\section{CONTENTS OF PART I.}

I.-ON SPLACHNIDIUM RUGOSUM GREV., THE TYPE OF A NEW ORDER OF ALGA. By MaRgaret O. Mitchell, former Bathurst Student, Newnham College, Cambridge, and Frances G. Whitring, former Student of Newnham College, Cambridge.

II.-ON A FOSSIL ALGA BELONGING TO THE GENUS CAU. LERPA, FROM THE OOLITE. BY THE EDITOR.

III.-ON THE STRUCTURE OF DICTYOSPHARIA DECNE. BY THE EDITOR.

IV.-ON MALFORMATIONS OF ASCOPHYLLUM AND DESMARESTIA. By Ethel Sarel Barton.

V.-ON CONCHOCELIS, A NEW GENUS OF PERFORATING ALGÆ. By E. A. L. Batters, B.A., LL.B., F.L.S.

PRICE 7s. 6d.

\section{CONTENTS OF PART II.}

VI.-NOTES ON THE MORPHOLOGY OF THE FUCACEAE: COCCOPHORA LANGSDORFII GREV. By A. LoRRAIN SMIth. SEIROCOCCUS AXILLARIS GREV. By A. Lorrain SMith. XIPHOPHORA BILLARDIERII MONT. By E. S. BARTON. NOTHEIA ANOMALA BAIL. and HARV. By M. O. MitchelL. SARCOPHYCUS POTATORUM KÜTZ. By F. G. WhitTING.

VII.-ON CHLOROCYSTIS SARCOPHYCI, A NEW ENDOPHYTIC ALGA. By F. G. Whitting.

VIII.-ON HALICYSTIS AND VALONIA. By THE EdITOR.

IX.-ON THE STRUCTURE OF HYDROCLATHRUS BORY. By M. O. MitcheLL.

X.-ON THE CRYPTOSTOMATA OF ADENOCYSTIS, ALARIA AND SACCORHIZA. By THE Editor.

XI.-A COMPARISON OF THE MARINE FLORAS OF THE WARM ATLANTIC, INDIAN OCEAN, AND THE CAPE OF GOOD HOPE. BY THE EdiTOR. 



\section{PHYCOLOGICAL MEMOIRS}

BEING

RESEARCHES MADE IN THE BOTANICAL DEPARTMENT OF THE BRITISH MUSEUM.

EDITED BY

GEORGE MURRAY, F.R.S.E., F.L.S.

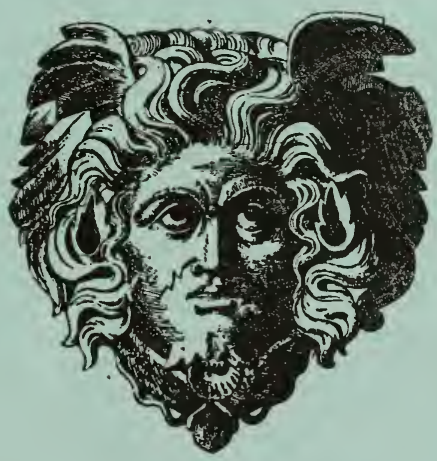

PART III.

DULAU AND CO., SOHO SQUARE, LONDON. APRIL, 1895 . 


\section{CONTENTS OF PART III.}

XII.-A NEW PART OF PACHYTHECA. By The EDITOR. XIII.-CALCAREOUS PEBBLES FORMED BY ALGA. By Thr Edtor. With LIST OF DIATOMS. By E. Grove.

XIV.-NOTES ON THE SORI OF MACROCYSTIS AND POSTELSIA. By A. L. Sмith and F. G. Whitting.

XV.-A COMPARISON OF THE ARCTIC AND ANTARCTIC MARINE: FLORAS. By The Editor and E. S. Barton.

PRICE 7s. 6d. 


\section{CONTENTS OF PART I.}

I.-ON SPLACHNIDIUM RUGOSUM GREV., THE TYPE OF A NEW ORDER OF ALGÆ. By Margaret O. Mitchell, former Bathurst Student, Newnham College, Cambridge, and Frances G. Whirting, former Student of Newnham College, Cambridge.

II.-ON A FOSSIL ALGA BELONGING TO THE GENUS CAU. LERPA, FROM THE OOLITE. By THE EDITOR.

III.-ON THE STRUCTURE OF DICTYOSPHARIA DECNE. By THE EDITOR.

IV.-ON MALFORMATIONS OF ASCOPHYLLUM AND DESMARESTIA. By Ethel Sarel Barton.

V.-ON CONCHOCELIS, A NEW GENUS OF PERFORATING ALGE. By E. A. L. Batters, B.A., LL.B., F.L.S.

PRICE 73. 6d.

\section{CONTENTS OF PART II.}

VI.-NOTES ON THE MORPHOLOGY OF THE FUCACEAE: COCCOPHORA LANGSDORFII GREV. By A. LORRAIN SMITH. SEIROCOCCUS AXILLARIS GREV. By A. LORRAIN SMITH. XIPHOPHORA BILLARDIERII MONT. By E. S. BARTON. NOTHEIA ANOMALA BAIL. and HARV. By M. O. Mitchell. SARCOPHYCUS POTATORUM KÜTZ. By F. G. WhITTING.

VII.-ON CHLOROCYSTIS SARCOPHYCI, A NEW ENDOPHYTIC ALGA. By F. G. Whitting.

VIII.-ON HALICYSTIS AND VALONIA. By THE EdITOR.

IX.-ON THE STRUCTURE OF HYDROCLATHRUS BORY. By M. O. Mitchell.

X-ON THE CRYPTOSTOMATA OF ADENOCYSTIS, ALARIA AND SACCORHIZA. By THE EDITOR.

XI.-A COMPARISON OF THE MARINE FLORAS OF THE WARM ATLANTIC, INDIAN OCEAN, AND THE CAPE OF GOOD HOPE. BY THE EDITOR. 





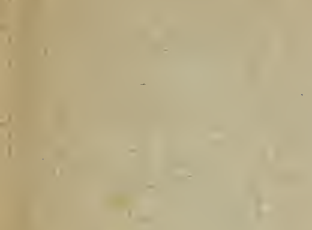

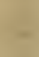

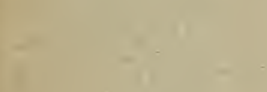

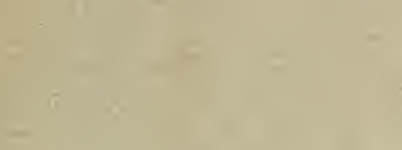

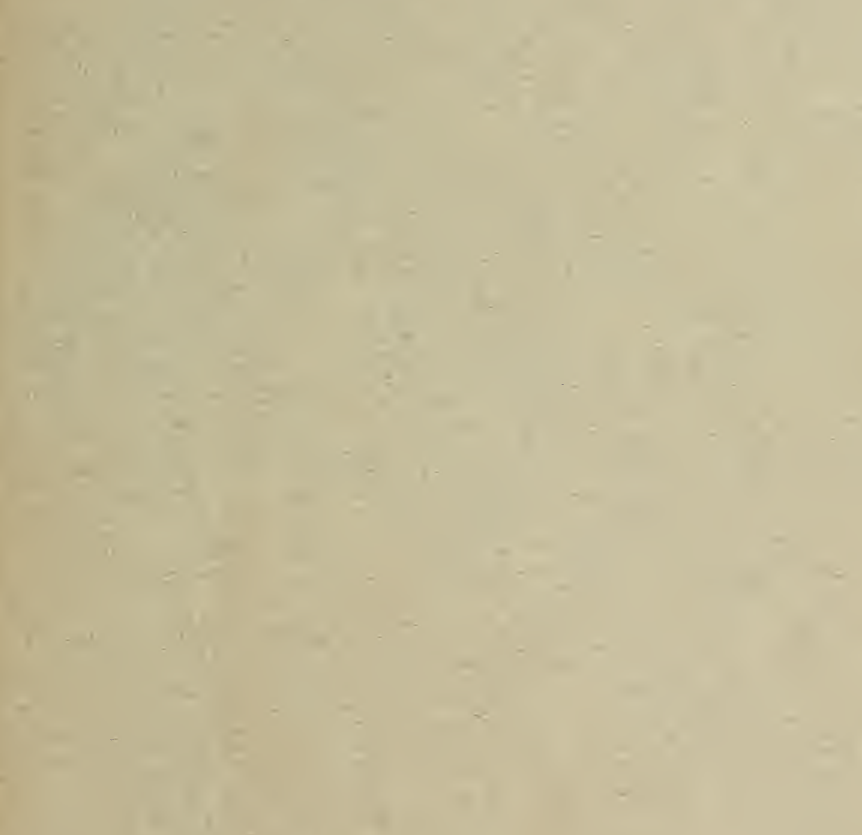




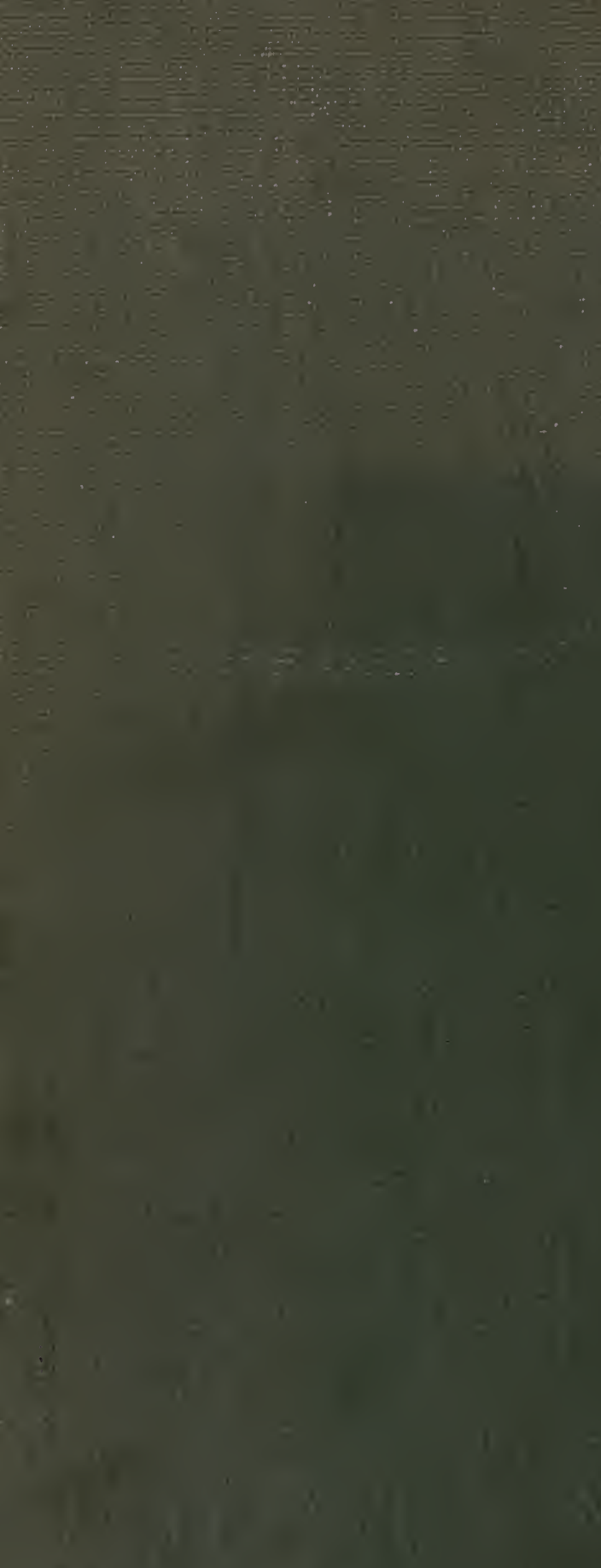

